Original Research Paper

\title{
Presents Some Aspects and Applications of Projective Geometry
}

\author{
Relly Victoria Virgil Petrescu
}

ARoTMM-IFToMM, Bucharest Polytechnic University, Bucharest, (CE), Romania

\section{Article history}

Received: 23-05-2019

Revised: 27-05-2019

Accepted: 10-07-2019

Corresponding Author:

E-mail: rvvpetrescu@gmail.com

\begin{abstract}
Projective geometry is that area of geometry that treats geometric figures from the point of view of the perspective and the horizon line, figures that are considered invariable by projection. The origins are found in the Pappus works of Alexandria (4th century AD), which, referring to the results of Apollonius in Perga, introduces the concept of an anarchic report. The study of projective geometry is later resumed by mathematicians like Pascal or architects like Gérard Desargues in the seventeenth century, to be theorized and taught in the late 18th century by Gaspard Monge. Jean-Victor Poncelet, through his work, the Traité des propriétés géométriques des figures, gives a strong leap to this science, but this is based on Euclidean geometry. However, the affine geometry excluded the possibility of an intersection of parallel lines, an essential notion in the projective geometry. But the 19th-century discoveries of August Ferdinand Möbius, Julius Plücker and especially Felix Klein's 1900s, definitively separate the projective geometry from the Euclidean one. There is also a conceptual revolution: If until then geometry was a science of figures, now the focus is on geometric transformations, the associated internal compositional laws, the structures of the various transformation groups.
\end{abstract}

Keywords: Robots, Mechatronic Systems, Automation, Projective Geometry, Geometric Figures, Perspective, Horizon line, Invariable by Projection

\section{Introduction}

Projective geometry is a branch of mathematics that studies relationships between geometric figures and images resulting from their design (mapping). Projections can be movies, maps of the Earth's surface, shadows of objects. Projective geometry has evolved from the need to understand perspective in drawing and painting. Each point of the projected object and the corresponding point of its image must be on the projector's radius, a line passing through the center of the projection. Modern projective geometry emphasizes mathematical properties (such as line continuity and intersection points) that are preserved in projections despite length, angle and contour distortions. Projective geometry is that area of geometry that treats geometric figures from the point of view of the perspective and the horizon line, figures that are considered invariable by projection. The origins are found in the Pappus works of Alexandria (4th century AD), which, referring to the results of Apollonius in Perga, introduces the concept of an anarchic report. The study of projective geometry is later resumed by mathematicians like Pascal or architects like Gérard Desargues in the seventeenth century, to be theorized and taught in the late 18th century by Gaspard Monge.

Jean-Victor Poncelet, through his work, the Traité des propriétés géométriques des figures, gives a strong leap to this science, but this is based on Euclidean geometry. However, the afine geometry excluded the possibility of an intersection of parallel lines, an essential notion in the projective geometry. But the 19thcentury discoveries of August Ferdinand Möbius, Julius Plücker and especially Felix Klein's 1900s, definitively separate the projective geometry from the Euclidean one. There is also a conceptual revolution: If until then geometry was a science of figures, now the focus is on geometric transformations, the associated internal compositional laws, the structures of the various transformation groups.

Unlike the Euclidean geometry, where the figures are made with ruler and compass, only ruler is required in the projective geometry. Projective geometry does not take into account parallelism or perpendicularity of straight lines, 
isometry, circles, isosceles or equilateral triangles. Uses only part of the axioms of Euclidean geometry.

The projective space is the set of all vector vectors of a vector space. If we imagine the observer placed in the origin of the vector space, then each element of the space corresponds to a direction of its gaze.

A projective space differentiates itself from a vector space by its homogeneous character: it does not contain any point that can be considered as the origin and thus resembles the affine space.

Descriptive Geometry is a mathematical branch of Projective Geometry and its fundamental problem is the transformation of three-dimensional space into twodimensional and reciprocal space. In other words, it deals with the representation of the geometrical figures in the three-dimensional space as well as with the deduction of the figures from the three-dimensional space starting from their plane representations.

In the technique, it is the theoretical foundation of the science of body representation on a plane and the deduction of its spatial form from its plane representations.

Descriptive geometry in the present form owe to Gaspard Monge (1746-1818; Fig. 1) a French engineer and mathematician who trained at the Polytechnic School of Paris.

At 25, he is a mathematics and descriptive teacher at the Military School in Mezieres.

In 1780, Monge's reputation reached Paris. Then Turgot, the minister of Louis XVI, entrusted him with the post of professor of hydraulics at the Louvre. In the same year he entered the Academy of French Sciences, although he was only 34 years old. Senator arrives from the Conservative party.

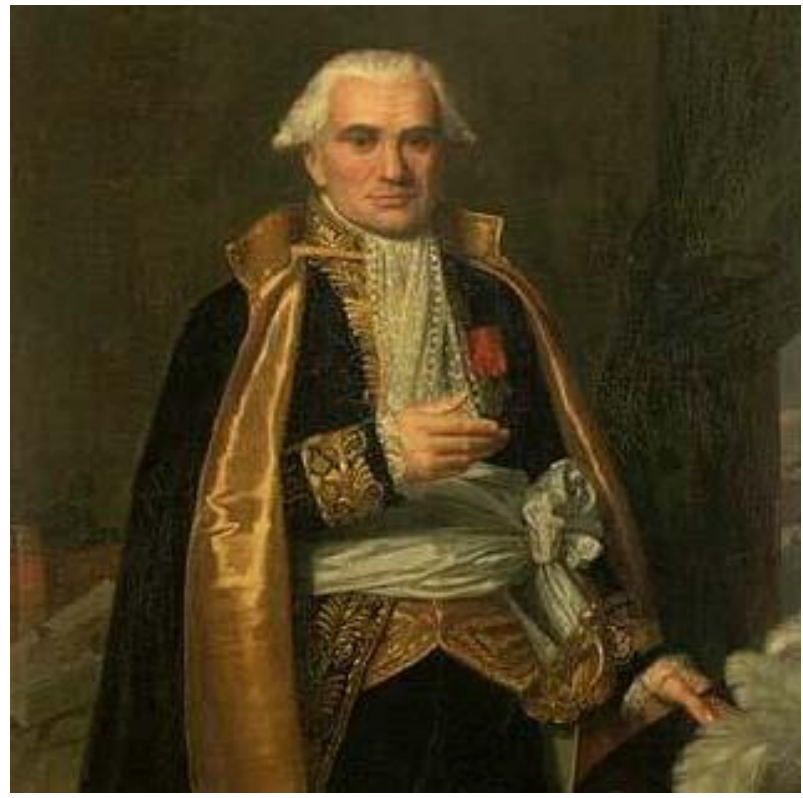

Fig. 1: Portrait of Gaspard Monge, (1746-1818)
In our country, the first elements of Descriptive Geometry were taught in Iasi, at the Hotarnici School of Engineers by Gheorghe Asachi and in Bucharest by Gheorghe Lazar at St. Sava College.

By an extension, Descriptive or Projective Geometry, it can be used to transform the Three-Dimensional Space into a Tetra-Dimensional Space and the other, being the only branch of mathematics that can directly describe a four-dimensional space.

Projective geometry-descriptive, positional, or synthetic-was discovered in 1799 by Gaspard de Monge, French engineer and mathematician. His equally brilliant student, Poncelet, an officer in Napoleon's army, took a step forward in this branch of geometry. After Napoleon's withdrawal from Moscow, he fell prisoner to the Russians and was captured in the city of Saratov on the Volga. During this period of captivity he developed the basics of projective geometry. The French and the Russians did not understand it initially, but the Germans accepted it in the "Crells Journal" magazine, which made the projective or descriptive geometry known throughout the world.

Researching the History of Descriptive Geometry of Professor Gino Loria1, Professor M. St. Botez2, remains disappointed that "among the countries that have cultivated Descriptive Geometry" is not mentioned Romania, which had an older and better mathematical education, for example Bulgaria . This shortcoming is attributable to the author's lack of information.

In his historical research, our great professor discovers a descriptive Geometry book, which can be said to be "the first of its kind in Romanian" 2; it is the translation into French of the French Treaty of Lefebure de Fourcy, entitled "Traits of Descriptive Geometry, precedes the introduction of queries on the theory of the plan and the leagues of the thesis". It was translated into Germany - Munich 1837 - by Georg Mayer3; in Portugal "Complemento di Geometria Descriptiva" by L. de Fourcy; in Romania by the architect Alexandru Orescu, professor, printing house of the National College, 1851, Bucharest.

I notice that in Romania it was translated before Portugal. M. St. Botez therefore rightly considers Al. Orescu was the first Professor of Descriptive Geometry in our country2.

The first volume, 283 pages, contains the text, the second, the purge 2:

- Introduction: the plane, the right, the angles between the straight and the straight and the plane

- Part I: descriptive treatment of the right, the plan, the sorting of the classes

- $\quad$ Part II: curved surfaces, rotating surfaces, crooked surfaces, hyperboloid and paraboloid, tangent plane, flat sections, body intersections

- Part III: The theory of crooked curves, the propeller

- Part IV: Exercises 
This organization of the teaching of Descriptive Geometry has been preserved to date. It is logically logical and easy for the student audience.

It is worth mentioning that the Hotarnici Engineers School introduced the study of Descriptive Geometry by Gheorghe Asachi in the second decade of the 19th century in Iasi and a few years later, the National School of Bridges and Roads (actual UPB), through Gheorghe Lazar in Bucharest.

The two schools mentioned above cultivated the study of Descriptive Geometry for Engineering, which was later implemented by Traian Lalescu and the Politehnica of Timisoara set up at its instigation and maintained as a natural continuity by the Politehnica in Iasi:

1. Gino Loria "Storia della Geometria Descrittiva de origini sino et giorni nostri", Ulrico Hoepli - Milano 1921

2. M. St.Botez "Descriptive Geometry Survey a Hundred Years Ago", Rev. Academic "V. Adamache", Vol. XXXIII, No. 1, 1947; Iasi, Printing House "Fight of Moldova", 1947

3. Gh. Țiţeica "Opere", Vol. 1, pg.III, Romanian Academy

Professor Alexandru Pantazi of Politehnica in Bucharest was born in Piatra Neamt on August 21, 1896, as an instigator son. At the end of high school (1914) he enrolled at the Faculty of Sciences of the University of Bucharest, the Mathematics Department. Due to the 1916-1918 war, Pantazi had to interrupt his studies, being mobilized as a lieutenant. After the war, in 1920, he took his mathematics license with the mention "very good" at the University of Bucharest and immediately left for Paris. Here he resumes his mathematics license at the Sorbonne in 1922, then prepares his doctoral thesis in mathematics, which he claims on January 12, 1922. The thesis was entitled "Sur applicabilitée projective des hypersurfaces développables". In this thesis, Pantazi deals with a series of generalizations of results found by his professor Elie Cartan, a creator in the field of Projective Geometry. Back in the country, Pantazi was appointed assistant to Gheorghe Ţiţeica at the Analytical Geometry Seminar. At the same time, he worked as an actuary at the Ministry of Industry and Commerce and a teacher at the School of Statistics and Actuarial. In 1940 he was appointed as a substitute for Descriptive Geometry and Projective Geometry at the Polytechnic School in Bucharest and in 1943 by competition, he was appointed the head of this department, where he practiced until his life's end. In the years 1946-1948, after Petre Sergescu's departure to France, Pantazi also replaced the Department of Analytical Geometry at Politehnica in Bucharest. In the years 1940-1942 Pantazi held at the University of Bucharest, the Faculty of Mathematics, a Higher Geometry course and a Geometric Applications course of Analysis (1938-1941).
Jean-Victor Poncelet (1788-1867; Fig. 2), a French mathematician, founder of "Proiective Geometry," taught at the Metz School of Mechanics and at the Faculty of Science as well as at the Polytechnic School, both in Paris.

In 1822, he published the "Traité des propriétés des projectives cifre", (1822; 2d ed., Vol. 2, 1865/66)

The theoretical basis of his new discipline, "Projective Geometry".

Some studies by Jean-Victor Poncelet the eminent student of G. Monge can be spotted in Fig. 3.

The earliest preoccupations in the fields of geometry and even Descriptive Geometry (even if not then named) belong to Apollonius of Perga (Greek Astronomer and Geometry, 262 BC), which was noted for its geometrical studies on conical sections; introduced for the first time the "notions of suspension points", "parabola", "hyperbola", "eccentric orbits", "epicicloids" etc ...

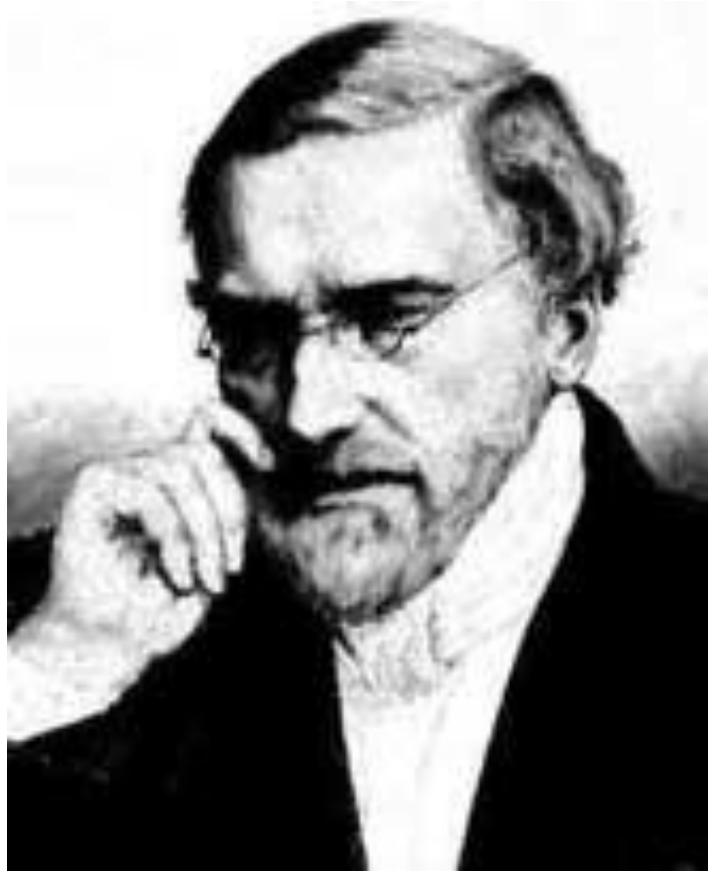

Fig. 2: Jean-Victor Poncelet (1788-1867)

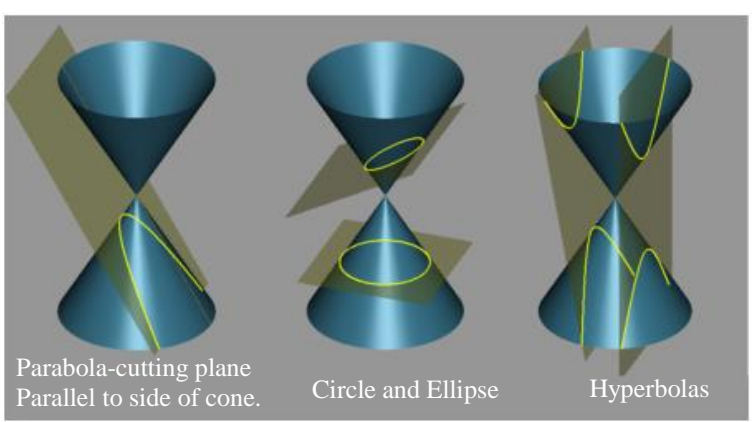

Fig. 3: Some studies by Jean-Victor Poncelet the eminent student of G. Mong 
Later, in 1728, in London, Ephraim's Encyclopedia "Universal Dictionary of Arts and Sciences" appears (see a photograph taken from this dictionary on cones and their study).

All these studies throughout history show that Descriptive Geometry has emerged before Projective Geometry, the latter developing it first and demonstrating more eloquently their importance in the evolution of engineering sciences (Rulkov et al., 2016; Agarwala, 2016; Babayemi, 2016; Gusti and Semin, 2016; Mohamed et al., 2016; Wessels and Raad, 2016; Maraveas et al., 2015; Khalil, 2015; Rhode-Barbarigos et al., 2015; Takeuchi et al., 2015; Li et al., 2015; Vernardos and Gantes, 2015; Bourahla and Blakeborough, 2015; Stavridou et al., 2015; Ong et al., 2015; Dixit and Pal, 2015; Rajput et al., 2016; Rea and Ottaviano, 2016; Zurfi and Zhang, $2016 \mathrm{a}-\mathrm{b}$; Zheng and Li, 2016; Buonomano et al., $2016 \mathrm{a}-\mathrm{b}$; Faizal et al., 2016; Cataldo, 2006; Ascione et al., 2016; Elmeddahi et al., 2016; Calise et al., 2016; Morse et al., 2016; Abouobaida, 2016; Rohit and Dixit, 2016; Kazakov et al., 2016; Alwetaishi, 2016; Riccio et al., 2016 a-b; Iqbal, 2016; Hasan and El-Naas, 2016; Al-Hasan and Al-Ghamdi, 2016; Jiang et al., 2016; Sepúlveda, 2016; Martins et al., 2016; Pisello et al., 2016; Jarahi, 2016; Mondal et al., 2016; Mansour, 2016; Al Qadi et al., 2016b; Campo et al., 2016; Samantaray et al., 2016; Malomar et al., 2016; Rich and Badar, 2016; Hirun, 2016; Bucinell, 2016; Nabilou, 2016b; Barone et al., 2016; Chisari and Bedon, 2016; Bedon and Louter, 2016; Santos and Bedon, 2016; Minghini et al., 2016; Bedon, 2016; Jafari et al., 2016; Chiozzi et al., 2016; Orlando and Benvenuti, 2016; Wang and Yagi, 2016; Obaiys et al., 2016; Ahmed et al., 2016; Jauhari et al., 2016; Syahrullah and Sinaga, 2016; Shanmugam, 2016; Jaber and Bicker, 2016; Wang et al., 2016; Moubarek and Gharsallah, 2016; Amani, 2016; Shruti, 2016; Pérez-de León et al., 2016; Mohseni and Tsavdaridis, 2016; AbuLebdeh et al., 2016; Serebrennikov et al., 2016; Budak et al., 2016; Augustine et al., 2016; Jarahi and Seifilaleh, 2016; Nabilou, 2016a; You et al., 2016; AL Qadi et al., 2016a; Rama et al., 2016; Sallami et al., 2016; Huang et al., 2016; Ali et al., 2016; Kamble and Kumar, 2016; Saikia and Karak, 2016; Zeferino et al., 2016; Pravettoni et al., 2016; Bedon and Amadio, 2016; Chen and $\mathrm{Xu}, 2016$; Mavukkandy et al., 2016; Gruener, 2006; Yeargin et al., 2016; Madani and Dababneh, 2016; Alhasanat et al., 2016; Elliott et al., 2016; Suarez et al., 2016; Kuli et al., 2016; Waters et al., 2016; Montgomery et al., 2016; Lamarre et al., 2016; Daud et al., 2008; Taher et al., 2008; Zulkifli et al., 2008; Pourmahmoud, 2008; Pannirselvam et al., 2008; $\mathrm{Ng}$ et al., 2008; El-Tous, 2008; Akhesmeh et al., 2008; Nachiengtai et al., 2008; Moezi et al., 2008; Boucetta, 2008; Darabi et al., 2008; Semin and Bakar, 2008; AlAbbas, 2009; Abdullah et al., 2009; Abu-Ein, 2009; Opafunso et al., 2009; Semin et al., 2009 a-c; Zulkifli et al., 2009; Marzuki et al., 2015; Bier and Mostafavi, 2015; Momta et al., 2015; Farokhi and Gordini, 2015; Khalifa et al., 2015; Yang and Lin, 2015; Chang et al., 2015; Demetriou et al., 2015; Rajupillai et al., 2015; Sylvester et al., 2015; Ab-Rahman et al., 2009; Abdullah and Halim, 2009; Zotos and Costopoulos, 2009; Feraga et al., 2009; Bakar et al., 2009; Cardu et al., 2009; Bolonkin, 2009 a-b; Nandhakumar et al., 2009; Odeh et al., 2009; Lubis et al., 2009; Fathallah and Bakar, 2009; Marghany and Hashim, 2009; Kwon et al., 2010; Aly and Abuelnasr, 2010; Farahani et al., 2010; Ahmed et al., 2010; Kunanoppadon, 2010; Helmy and El-Taweel, 2010; Qutbodin, 2010; Pattanasethanon, 2010; Fen et al., 2011; Thongwan et al., 2011; Theansuwan and Triratanasirichai, 2011; Al Smadi, 2011; Tourab et al., 2011; Raptis et al., 2011; Momani et al., 2011; Ismail et al., 2011; Anizan et al., 2011; Tsolakis and Raptis, 2011; Abdullah et al., 2011; Kechiche et al., 2011; Ho et al., 2011; Rajbhandari et al., 2011; Aleksic and Lovric, 2011; Kaewnai and Wongwises, 2011; Idarwazeh, 2011; Ebrahim et al., 2012; Abdelkrim et al., 2012; Mohan et al., 2012; Abam et al., 2012; Hassan et al., 2012; Jalil and Sampe, 2013; Jaoude and El-Tawil, 2013; Ali and Shumaker, 2013; Zhao, 2013; El-Labban et al., 2013; Djalel et al., 2013; Nahas and Kozaitis, 2013; Petrescu and Petrescu, 2014 a-i, 2015 a-e, 2016 a-d; Fu et al., 2015; AlNasra et al., 2015; Amer et al., 2015; Sylvester et al., 2015b; Kumar et al., 2015; Gupta et al., 2015; Stavridou et al., 2015b; Casadei, 2015; Ge and Xu, 2015; Moretti, 2015; Wang et al., 2015; Antonescu and Petrescu, 1985; 1989; Antonescu et al., 1985a; 1985b; 1986; 1987; 1988; 1994; 1997; 2000a; 2000b; 2001; Aversa et al., 2017a; 2017b; 2017c; 2017d; 2017e; 2016a; 2016b; 2016c; 2016d; 2016e; 2016f; 2016g; 2016h; 2016i; 2016j; 2016k; 2016l; 2016m; 2016n; 2016o; Cao et al., 2013; Dong et al., 2013; Comanescu, 2010; Franklin, 1930; He et al., 2013; Lee, 2013; Lin et al., 2013; Liu et al., 2013; Padula and Perdereau, 2013; Perumaal and Jawahar, 2013; Petrescu, 2011; 2015a; 2015b; Petrescu and Petrescu, 1995a; 1995b; 1997a; 1997b; 1997c; 2000a; 2000b; 2002a; 2002b; 2003; 2005a; 2005b; 2005c; 2005d; 2005e; 2011a; 2011b; 2012a; 2012b; 2013a; 2013b; 2013c; 2013d; 2013e; 2016a; 2016b; 2016c; Petrescu et al., 2009; 2016; 2017a; 2017b; 2017c; 2017d; 2017e; 2017f; 2017g; 2017h; 2017i; 2017j; 2017k; 2017l; 2017m; 2017n; 2017o;2017p; 2017q; 2017r; 2017s; $2017 \mathrm{t} ; 2017 \mathrm{u} ; 2017 \mathrm{v} ; 2017 \mathrm{w} ; 2017 \mathrm{x} ; 2017 \mathrm{y} ; 2017 \mathrm{z}$; 2017aa; 2017ab; 2017ac; 2017ad; 2017ae; 2018a; 2018b; 2018c; 2018d; 2018e; 2018f; 2018g; 2018h; 2018i; 2018j; 2018k; 20181; 2018m; 2018n).

\section{Materials and Methods}

In the Fig. 4 one can see the perspective of a point and two points, this being the basic way in which the projective geometry is conceived.

In the Fig. 5 one can see the perspective of three points.

Figure 6 sows the center of perspectivity and the axis of perspectivity.

Several sections are used to help draw the drawing together with the respective perspectives (Fig. 7). The visibility of the perspectives and the section increases if shades of different nuances and colors are used. 


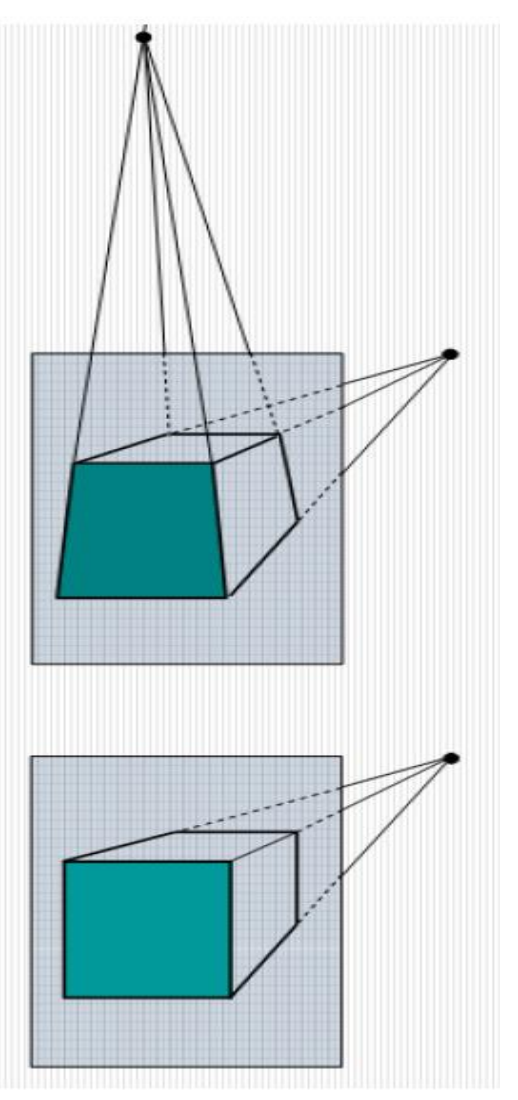

Fig. 4: The perspective of a point and two points

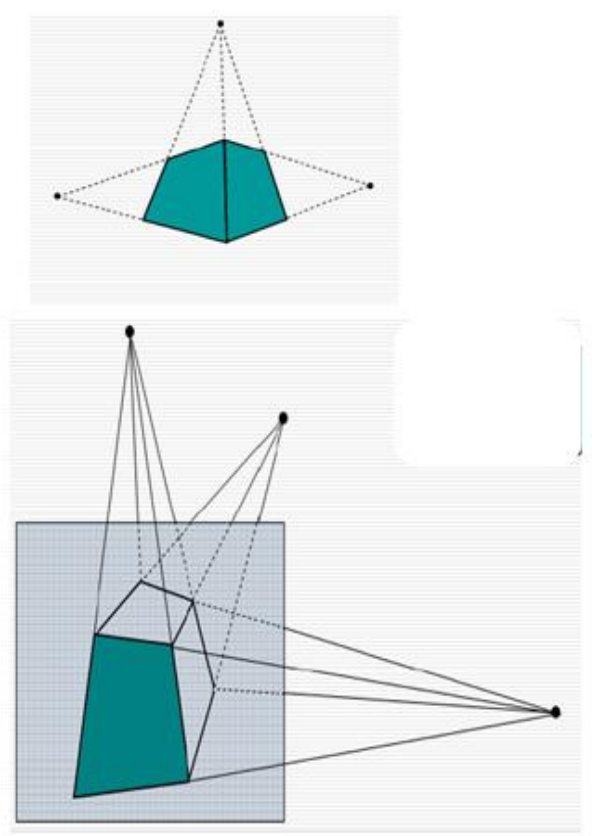

Fig. 5: The perspective of three points

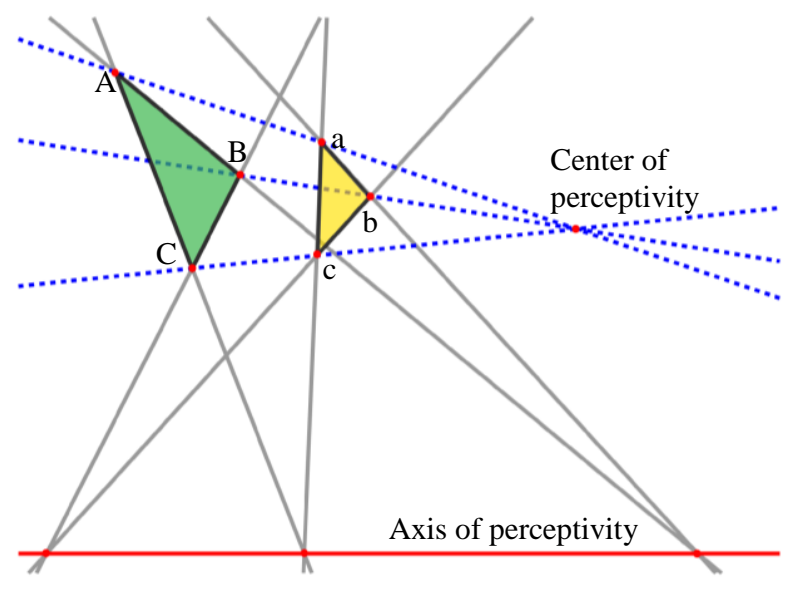

Fig. 6: The center of perspectivity and the axis of perspectivity
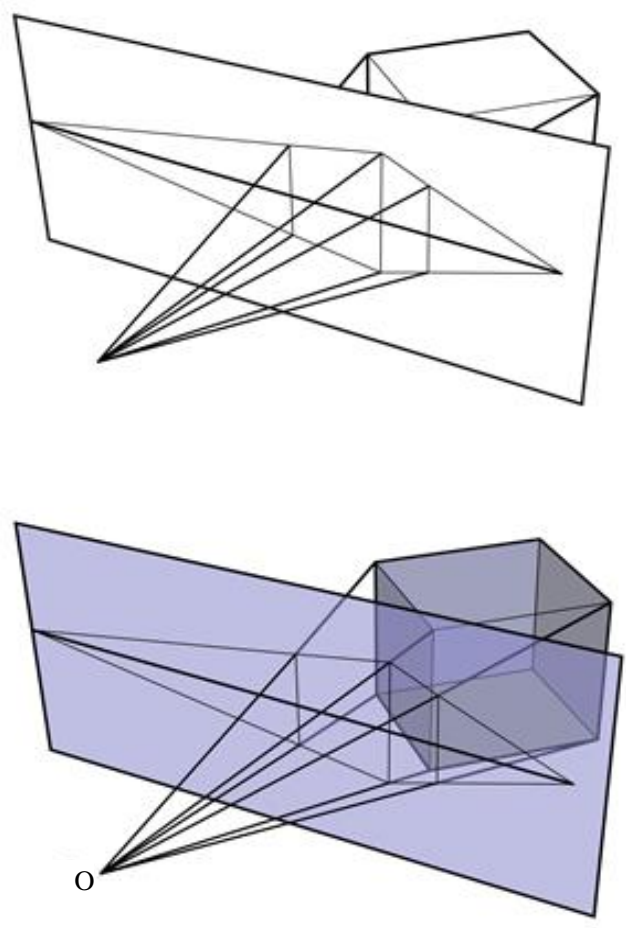

Fig. 7: Sections are used to help the drawing together with the respective perspectives

Figures 8-12 show some immediate applications for representing images using projective geometry. They are useful in the technique of artistic photography and industrial design as well as in architecture, although the projective geometry and its more modern descriptive side are practically two mathematical and engineering sciences.

\section{Results and Discussion}

H Points A, B, C, D and A '. B ', C', D 'are linked by a biunivoca projective transformation. 


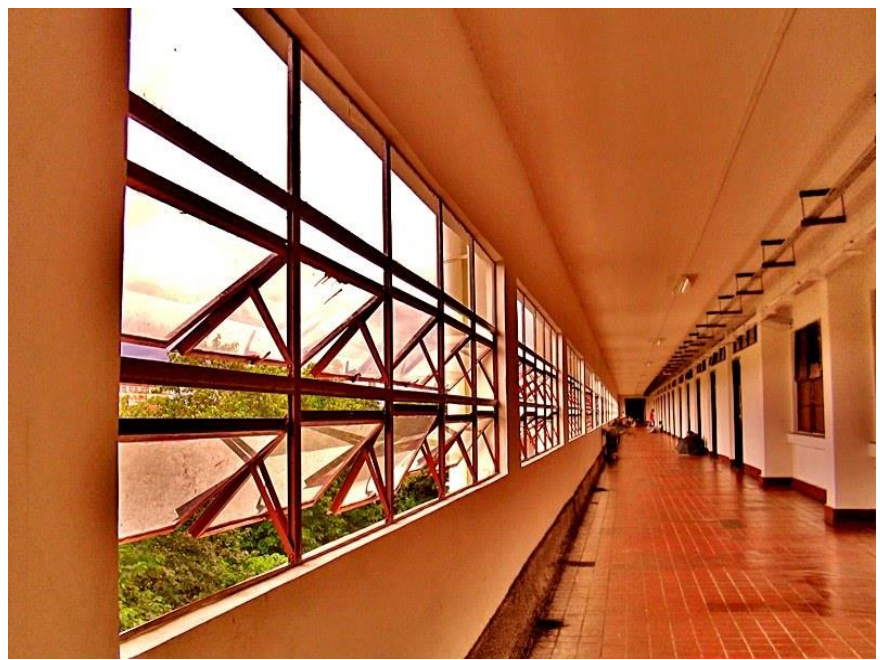

Fig. 8: Uses of projective geometry in the technique

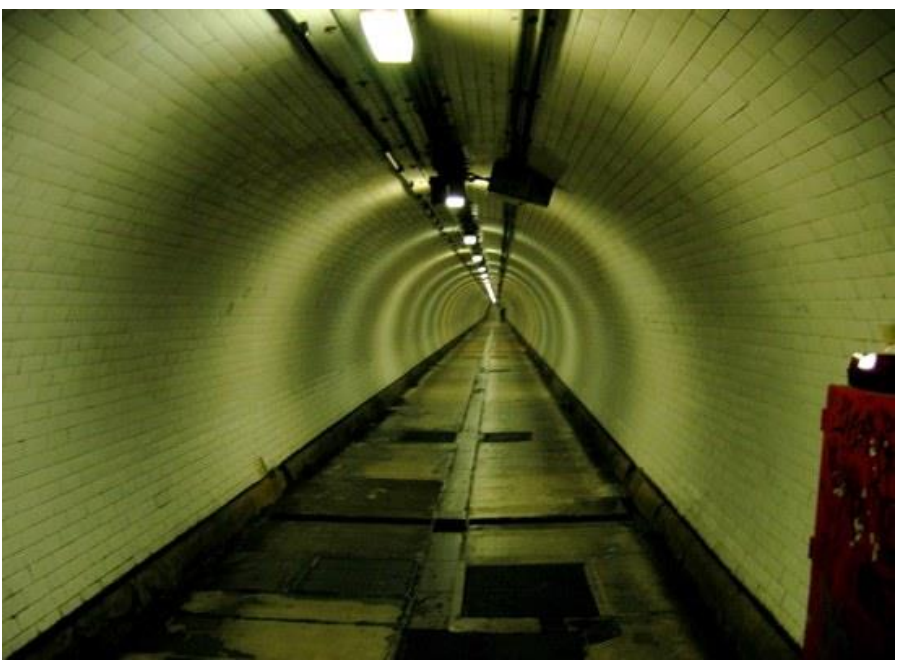

Fig. 9: Uses of projective geometry in the technique

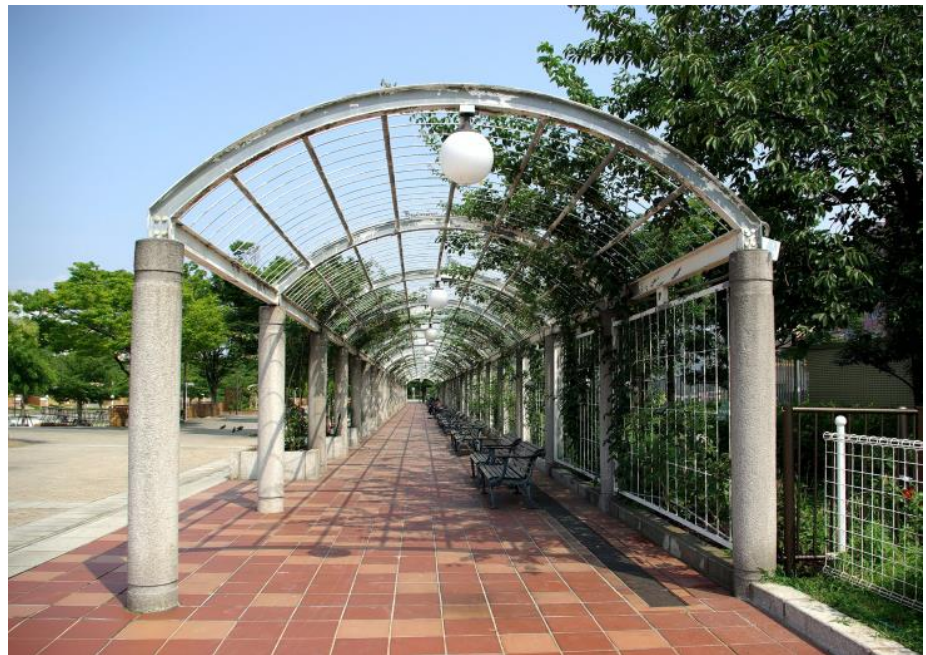

Fig. 10: Uses of projective geometry in the technique 


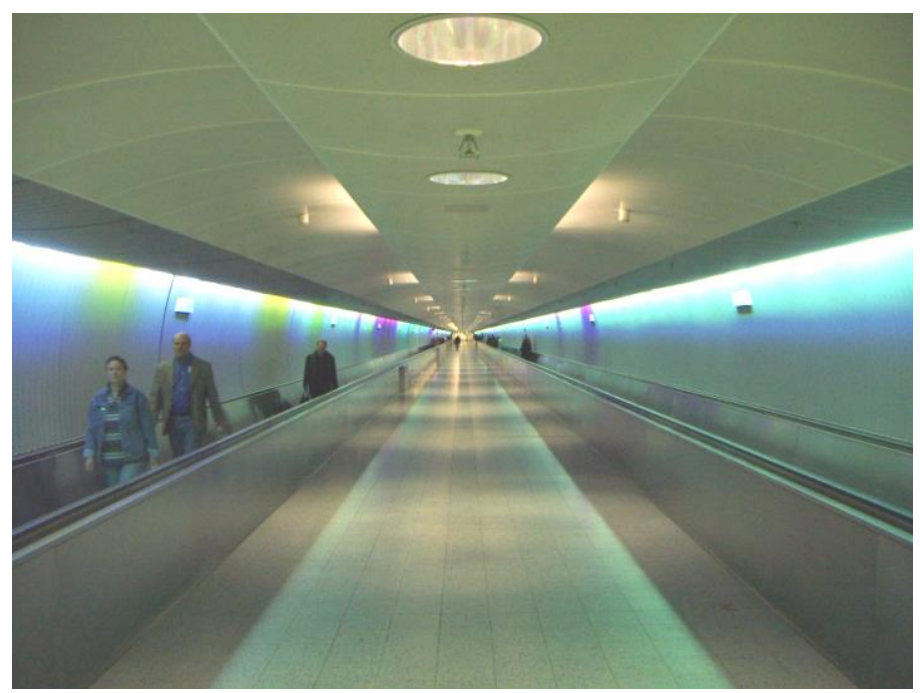

Fig. 11: Uses of projective geometry in the technique

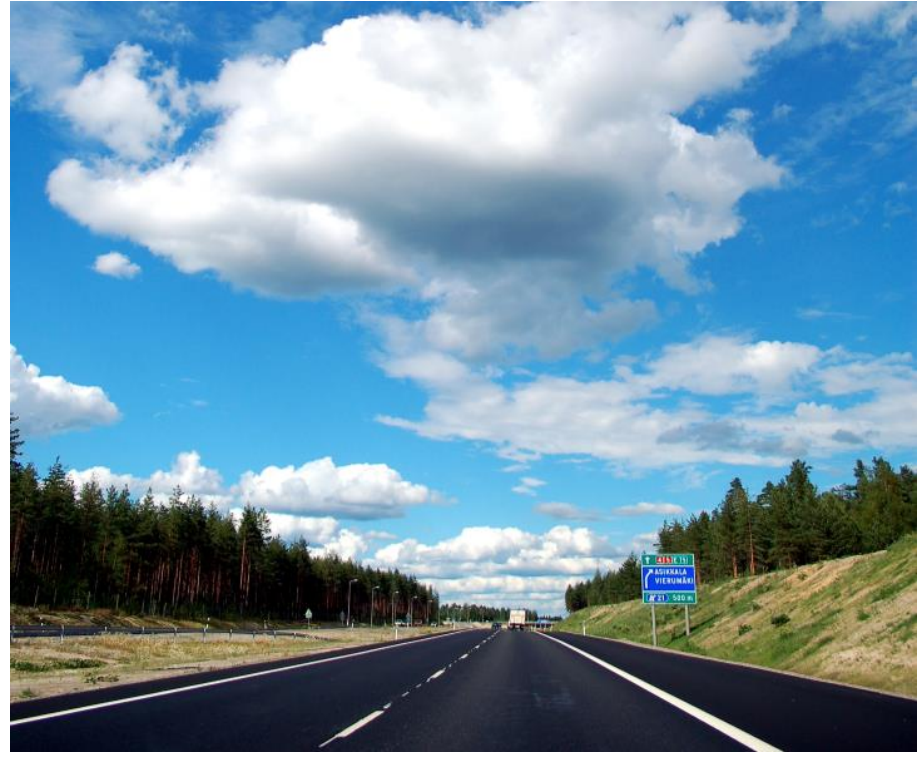

Fig. 12: Uses of projective geometry in the technique

A bi-linear and linear correspondence between two projective forms of the same (Fig. 13).

Linear correspondence $=$ the correspondence of elements belonging to $\mathrm{F}$ are incidental to elements belonging to $\mathrm{F}^{\prime}$.

Obs: If the corresponding elements are the same, then the homography is called colinization and if they are different then it is called reciprocity.

Desargues's Theorem: If the two triangles have the vertices on three competing lines, then the homologous sides are cut into three collinear points (Fig. 14).

Reformulation. If A, B, C, A', B', C 'are different points and $\mathrm{AA}^{\prime} \cap \mathrm{BB}^{\prime} \cap \mathrm{CC}^{\prime}=\{\mathrm{O}\}$, then the intersection points of

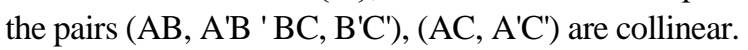

In the figure, the points $\mathrm{A}, \mathrm{B}, \mathrm{C}$ can move freely and A ', B', C 'only move on half-axles OA, OB, OC. The ribs whose intersections are of interest are colored the same; 'Desargues' right' is the red one (passes through $\mathrm{K}, \mathrm{L}, \mathrm{M}$ ).

The purpose of this script is to convince us of the correctness of the theorem and perhaps to introduce ideas for solving or applying.

In this case, the planes $(\mathrm{ABC})$ and $\left(\mathrm{A}^{\prime} \mathrm{B}^{\prime} \mathrm{C} \mathrm{C}^{\prime}\right)$ are different, so they are parallel or they are intersecting after a right d. Given the given conditions (the problem assumes the existence of the three intersection points, so $(\mathrm{ABC})\left(\mathrm{A}^{\prime} \mathrm{B}^{\prime} \mathrm{C}^{\prime}\right)=\mathrm{d}$.

As $\{K\}=A B \cap A^{\prime} B$ 'otinem $K \in A B \subset(A B C), K \in$ $A^{\prime} B \subset\left(A^{\prime} B^{\prime} C^{\prime}\right)$, so $K \in A(A B C)$, ie $K \in d$. 


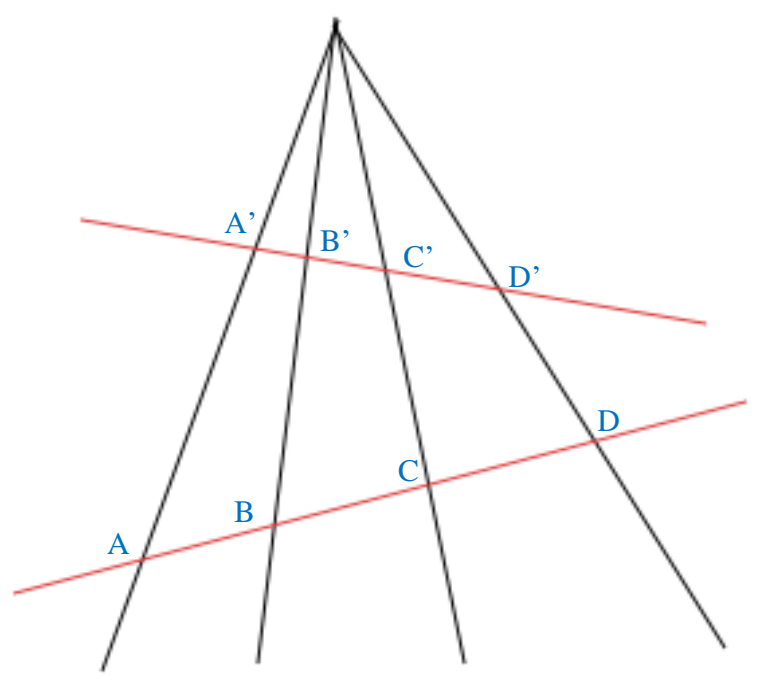

Fig. 13: Points A, B, C, D and A '. B ', C', D 'are linked by a biunivoca projective transformation
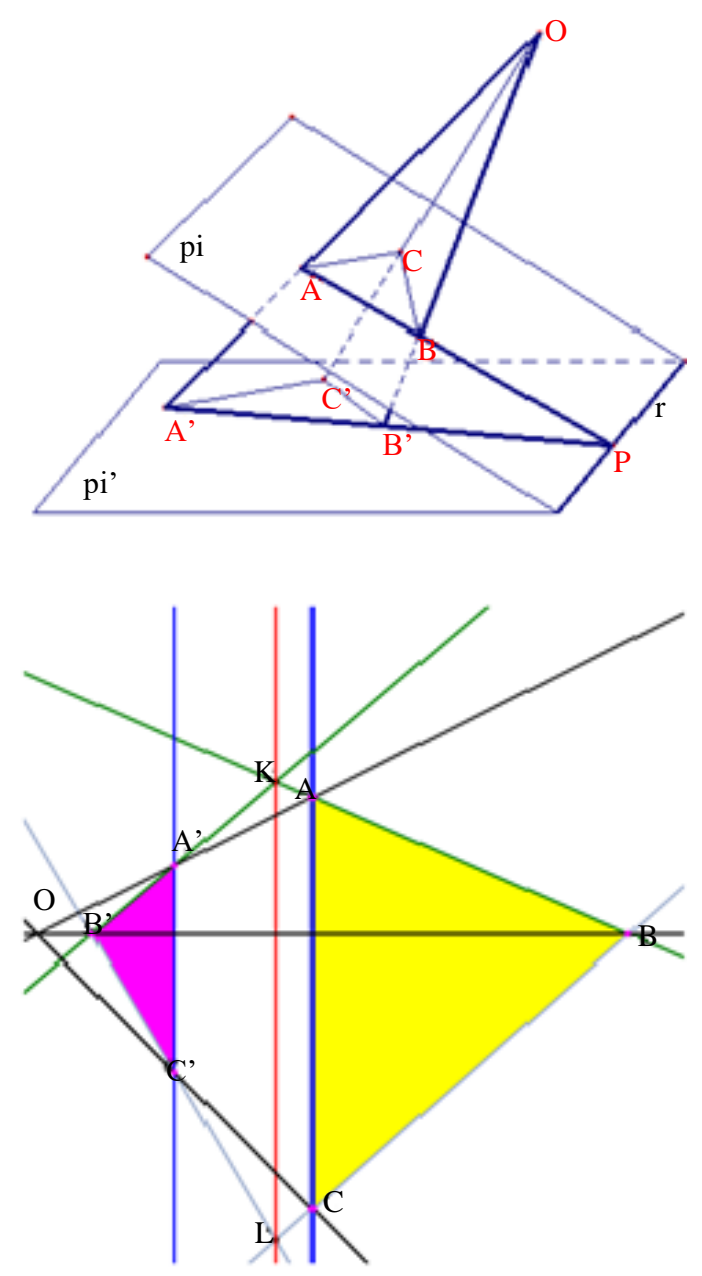

Fig. 14: Desargues's Theorem. Source: Desargues's Theorem demonstration

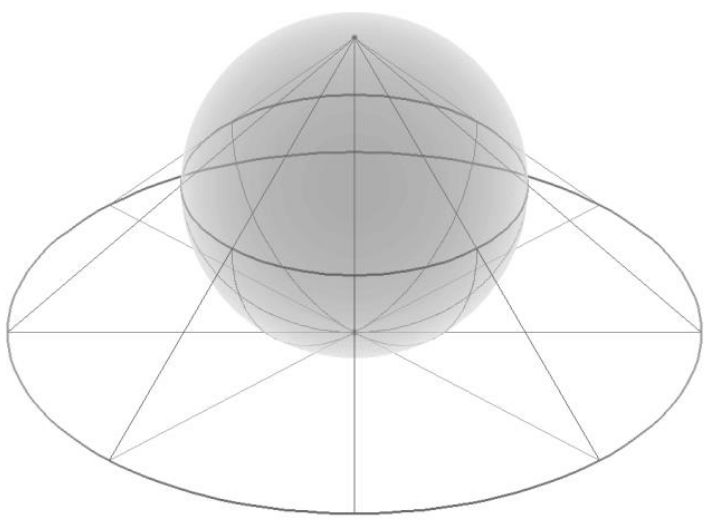

Fig. 15: Using The Desargues's Theorem in Space

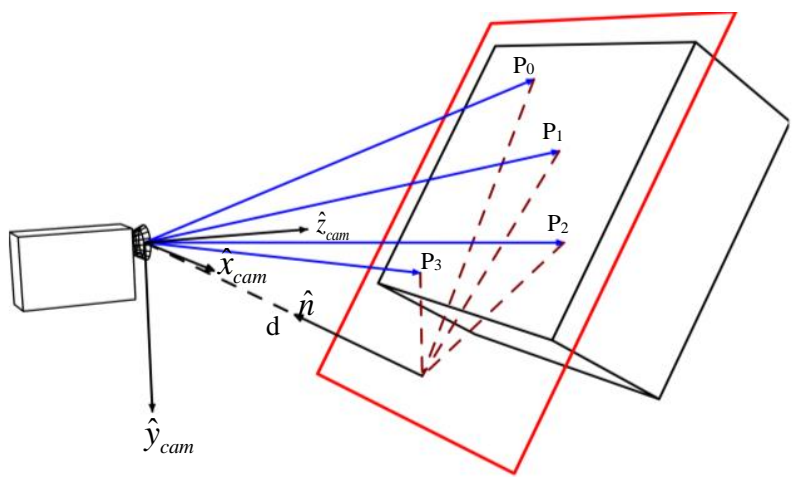

Fig. 16: The Central Projection System

Analog for $\mathrm{M}$ and L, so K, L, M are 'd-collinear (Desargues's Theorem demonstration).

If all points are coplanar, you can use Menelaus's theorem.

It uses the Desargues's Theorem in space (Fig. 15).

The Central Projection System can be seen in Fig. (16).

Projective representations can be perspective or correlated (the correlated representations of the straight lines on a plane - they can be performed with the beam of tangents in a second order curve, in space - with the beam of rays - tangent to the second-order surfaces), they are well defined, for example, in the representation of a straight line on the other, a point on the right-hand right belongs to a single point on the right-hand side. Such points are called Correspondents. Straights, related to the possibility of mutual design, as well as points, are called straight correspondences. Going to the corresponding planes, we can talk about a correspondence of points and lines where it is possible to match the points and their own lines with the improper ones.

Straights, planes and spaces can be in correlation or perspective. In the latter case, constructive elements of the second order appear to be planar plane planes arranged on the second order. 
In the group of projective representations, as a particular case, are the perspectives and blueberries. Transforming the perspective differs from those that, when representing a straight line, one of the points becomes double or unchanged. In the perspective view of a plane on a different plane (in space) double becomes a pair of congruent lines of these planes. Congruent lines are called two of their own lines, which can overlap each other in such a way that all their corresponding points will overlap and become double. In the perspective view of a plane on another plane, they will intersect after the mentioned double right, which in the given case will also be called the perspective axis.

The affine representation is the second most important special case of projective representations and it is distinguished by the fact that the improper elements of the construction after the transformation of the blue remain inappropriate. Therefore, any family of parallel lines of plan or space pass into a family of parallel steps corresponding to the plan or space transformed and any straight point disposed orderly and uniformly passes it in a straight line with corresponding points arranged evenly and orderly. However, it should be borne in mind that if on the right hand side the points are unevenly arranged, then the unevenness of the points is kept after the blue transformation. The corresponding points on the right-hand side will be positioned so that the ratio between the corresponding lengths on the right and the right one will be a constant size - the constant of this transformation. In plan, all the elements are stretched and shortened in two perpendicular directions, called the main conjugate diameters of blueberries. Such perpendicular conjugated diameters in space are three. In metric terms on the main conjugated diameters the deformations of the figures are extreme.

Special cases of blueberries are: kinship transformations, pure affine, conforming and congruent movement.

In the kinship transformations the corresponding plans-blueberries must have a pair of straight ones that are matching congruent. In relation to them, all the stacked position matching points must perform a symmetrical proportional elongation or tilting of a plane relative to another.

When moving purely to the double-right, the points of the transformed plane move in the directions parallel to that line, so that the farther away from it, the more it moves directly proportional to it.

In conforming transformation, proportional extension of the figures takes place in all directions evenly from a double point. However, the directions and angles, constructed from a point in the original plan (initial space), retain their value in the transformed plane, if these are the respective directions and angles.

Congruent representation - is a particular case of conforming representation when there is no deformation of the figures, but overlapping of planes or spaces occurs through translations and rotations, so that elements corresponding to the original and transformed space overlap and become double.

Under the name of the beam, planes and second order ruled surfaces, we will agree to understand the multiple combinations of these elements, combined with specific stable elements: dot, straight, plane. Fascils have projective properties, linking the points and the straight lines of the planes or spaces.

The best known is the beam of projective rays and the planes of the central projection image, which we will agree to call a beam with a central point because the rays and planes in this beam belong to a single point - the projection center.

Less well-known, but to be mentioned in this course, will be the bilinear beam, the unilinear beam and the multilinear beam of second-order rays, planes and surfaces.

Bilateral straight-beam, planes and rudimentary surfaces of the second order are part of a special group of three straight lines, two of which intersect with each other and the third intersects the first two.

The unilinear beam - also consists of the same elements but belonging to a single straight line.

The multilinear beam - also consists of the same elements and is the total of the bilinear bundles, the special lines of which are on two intersecting planes, having a common line.

All projective transformations to be studied further have an important property, called incidence, maintaining the belonging of the points of the straight, the planes of the planes, the planes of the space.

Consequently, keeping the order of the points on the right, of the planes on the plane and of the planes in space, their overlapping is excluded.

\section{Geometric Buildings and Plan Projects Representations}

One will study from the beginning the affine representation of the straight on a straight line in the beam of projective rays.

In Fig. 17 are two affine representations. One - in a beam with a center point with projection center $\mathrm{S}$ perspective and second - in a straight line, tangent to a second-order curve, - correlated. In the latter case, the correct straight lines - the blue ones are arranged to one another arbitrarily and they become tangent to the same curve.

It is easy to notice that perspective correspondence is a particular case of correlated correspondence when the corresponding straight lines are parallel to one another and the projection center $\mathrm{S}$ can be outside the space between these straight lines and within it. 
The affine correspondence of the straight lines in the fascicle is also maintained when the projection center of the straight beam becomes improper and the projection rays are parallel to each other (Fig. 18).

Correlative correspondence in the straight beam, tangent to the second order curve, is also preserved in the general projective correspondence of two straight lines (Fig. 19), being represented in their perspective in the central point beam, situated one-sided on the other.

Thus, irrespective of the projective correspondence of two straight lines, including all special cases, to their arbitrary arrangement with one another, the rays joining the corresponding points of these straight lines together with the respective lines form a set of tangents to a curve of order two. Consequently, a second-order curve in the

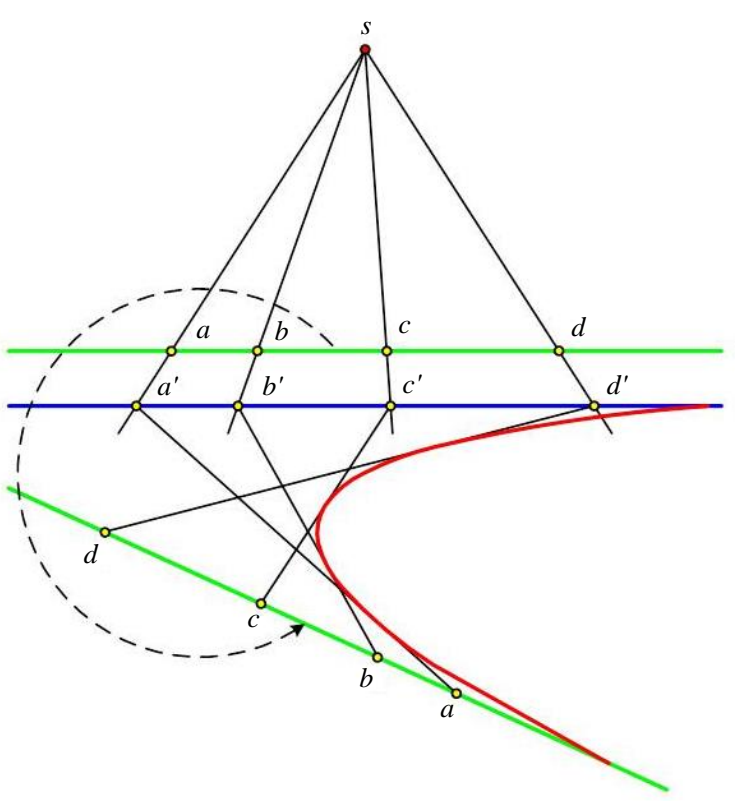

Fig. 17: Two affine representations

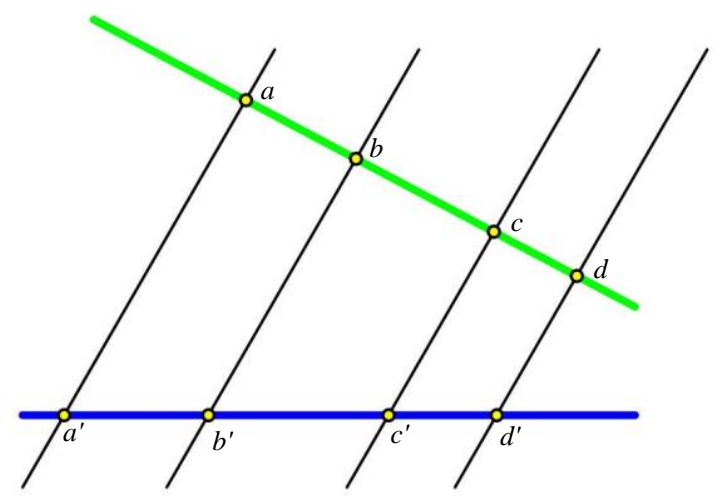

Fig. 18: Representing the affine of the straight into a beam of parallel rays (the center is located at infinity) plane can be constructed using two straight lines, which are in a projective correspondence, for example in a congruent correspondence (Fig. 20).

Two straight projective correspondents have two specific points $\mathrm{V}$ and $\mathrm{c}(\mathrm{c} /)$ (Fig. 10), which are easy to find if you put them in a perspective correspondence in a straight-line beam. One of the points is at the intersection of these straight lines and is double and the second $\mathrm{c}$ and c/are located at $\mathrm{V}$ at equal distances. Or $\mathrm{Vc}=\mathrm{Vc} /$.

Therefore, two corresponding projective lines may be superimposed in the plane so as to form a double straight with two double points $\mathrm{V}$ and $\mathrm{c}$.

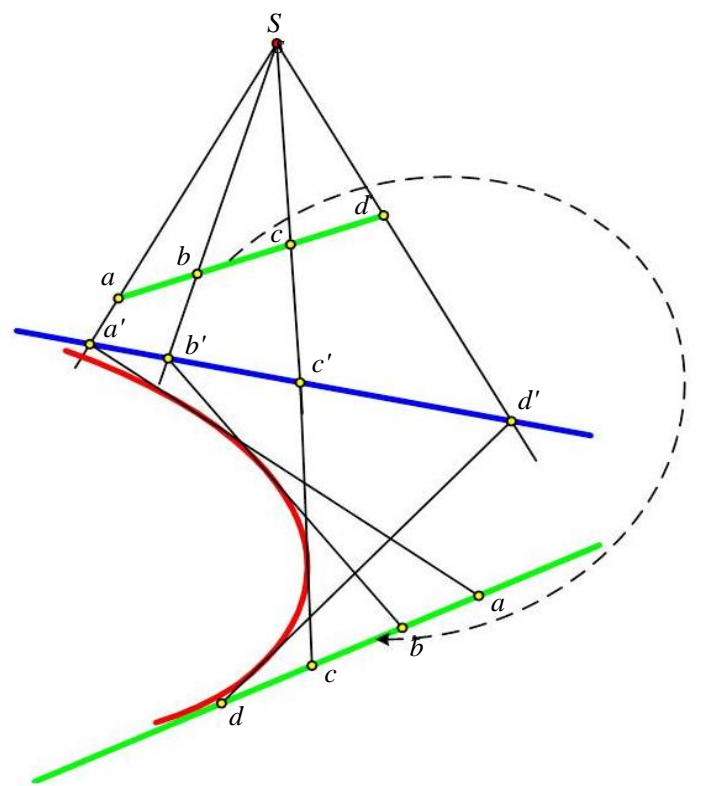

Fig. 19: The projective representation of the line of the general position in the rays beam with a central point (perspective) and in the rays beam tangent to a second order curve (correlative)

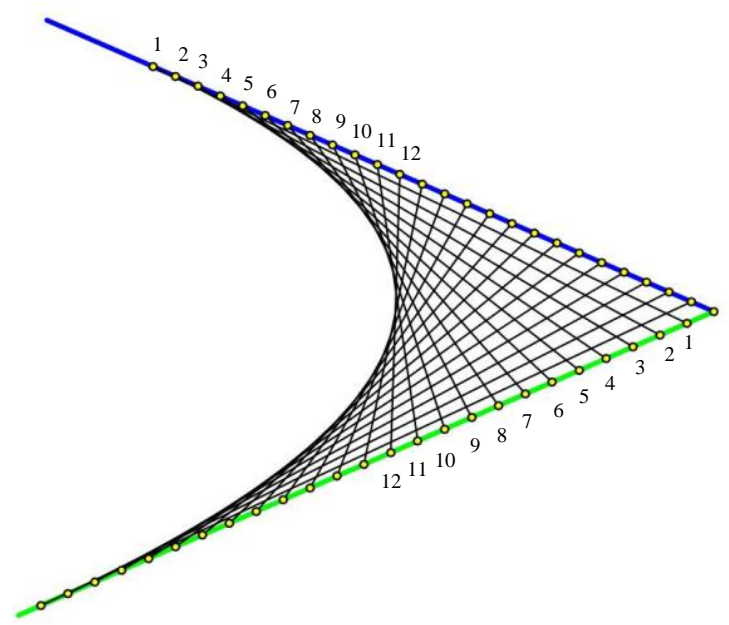

Fig. 20: Construction of the second order curve with two congruent straight lines 
In the affine of the straight lines in the centralbeam beam (see Fig. 7 or 6), their overlapping double point will be one. In Fig. 6 points, the points $\mathrm{c}$ and $\mathrm{c} /$ (see Fig. 10) are formally located on the perpendicular, lowered from the projection center $S$ and at the intersection of the corresponding straight lines (see Figure. The second pair of points, superimposed on point V (see Fig. 10), will be infinite.

Therefore, the role of points c and c/(see Fig. 10) on the blue correspondent lines (see Fig. 6 and 7) can play any matching point pair. Thus, two corresponding straight lines in their overlapping in the double straight can have a single double point. However, this role may play a pair of own points corresponding to these straight lines. In the case of the congruence of the straight lines they can be overlapped with all the points and as a result, this double straight line will entirely consist of double points (Fig. 21).

\section{Projective Correspondence of Straight-Line Beams with Central Points}

Straight-point projective correspondent beams, as well as straight projective correspondents, can be in mutual correspondence, both perspective and correlation. This is conditioned by their mutual position in the plan.

If two projections of central point projective correspondence are in a reciprocal perspective (Fig. 22), then at the intersection of the corresponding rays aa/ ... dd/, there will be obtained a row of collinear points 1, 2, 3, 4 - a straight line.

If the same two beams are different from one another, then a second order curve 1, 2, 3, 4, S, S/ (Fig. 23).

However, it should be borne in mind that if the fascicle centers are on both sides of a straight line, as in Fig. 22, then one of the beams, for example $S, a, b, c, d$, must be placed in the plane, in reverse (in the mirror), which means that the order of location in the fascicles, of the corresponding straight lines, must either identical to those of your watch or clockwise.

The second order curve, to the mutual correspondence of two correlated straight beams, will be obtained, regardless of their orientation, except for one perspective, when a right is formed at the intersection of the corresponding rays. From that perspective of two corresponding projective ray beams, it must be considered as a particular case of projective correspondence.

\section{Projective Representations of Plans and Clusters}

Projective representation of planes and bundles can be done in space and in plan (homology). Projective representations of center-point bundles can only be implemented in space because the plane bundle is a spatial construction.

Under the name of bundles we generally agree to understand the construction of lines, planes and rusted surfaces of the second order, which ensure a projective correspondence of two objects and their component parts, in this case of the planes, which is the link between their points - straight or straight rays - with planes or ruled surfaces of the second order, planes with monolithic or bilinear beams.

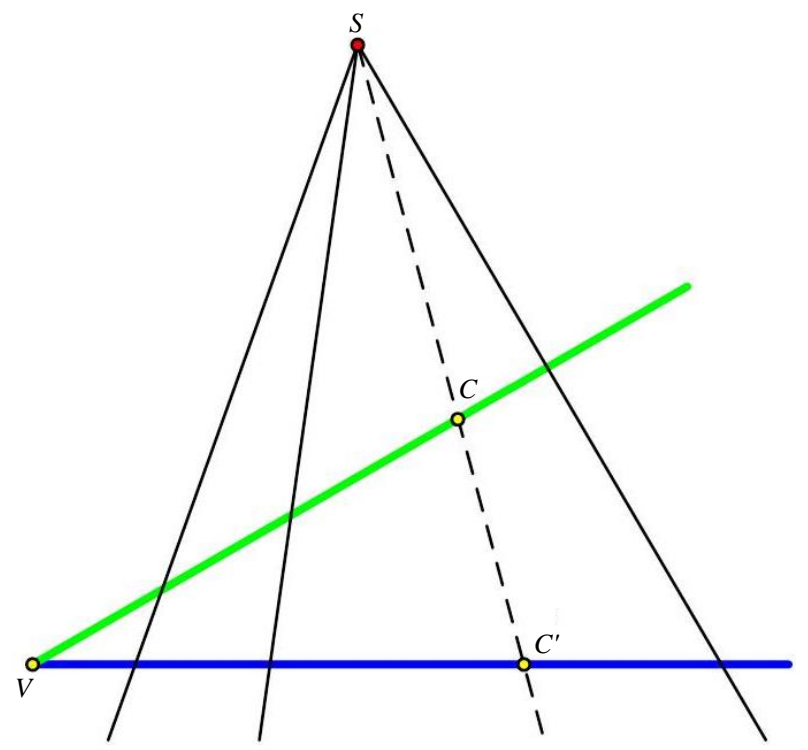

Fig. 21: The double points of the projective correspondent lines

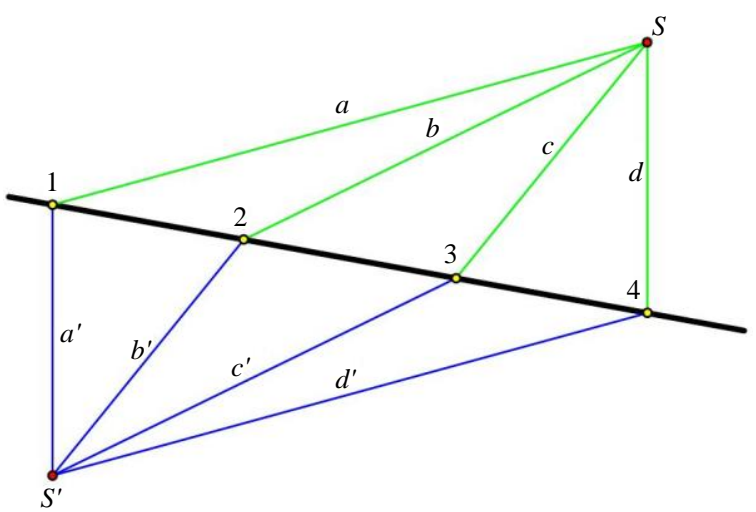

Fig. 22: Correspondence perspective of two straight-line beams with a central point

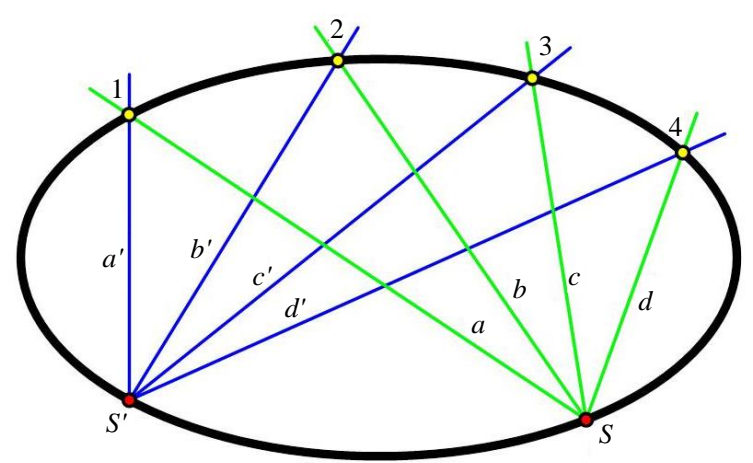

Fig. 23: Correlative correspondence of two rays beams with central points 


\section{Representing the Perspective of Planes}

The plan view representation is carried out in the bundle of projective ray with a central point, consisting of direct and planar rays, belonging to a point-the center of the bundle (Fig. 24). The corresponding projective planes $\mathrm{P}$ and $\mathrm{E}$ in the perspective of the beam and plane with the center point must have two straight lines which are correspondingly congruent and in perspective they must be overlapping at all their points forming a double straight line, full of double points. Such a line in Fig. 24 is VV right. The double VV right can be both proprietary and improper. In the latter case the planes must be in correspondence and placed in the bundle with a central point parallel to one another.

The projection center can be placed on one side of the planes as well as between them.

If the projection center $\mathrm{S}$ is moved infinitely, then the bundle will become a set of parallel lines between them and planes intersecting on these straight lines. In this case (Fig. 25) the representation of plan E on $\mathrm{P}$ and vice versa, called kinship representation, is ensured. Both said (conforming and kinship) representations are particular cases of affine representation.

Consequently, the bundle of projective ray with a central point, especially with its own center, does not ensure the bevel transformation of the general position planes, which is not always taken into account in the known works of projective geometry.

Two corresponding blue-plane planes do not have matching congruent lines.

\section{The Basic Constructive Elements of the Perspective Correspondence of the Planes}

The basic constructive elements of plan view correspondence (Fig. 26) are: the corresponding planes $\mathrm{P}$ and E; horizon planes $\Theta_{E}$ and $\Theta_{P}$; the $S_{P} i_{E} V$ main vertical plane; the aftermath of the plan $\Theta_{P}$ (in plan E) and of the plan $\Theta_{E}$ (plan P), passing through the $\mathrm{i}_{\mathrm{E}}$ and $\mathrm{i}_{\mathrm{P}}$ points called horizon lines; following the intersection of the planes $\mathrm{P}$ and $\mathrm{E}$, passing through the point $\mathrm{V}$, which belongs simultaneously to the plan of the main vertical; the principal verticals of the corresponding $\mathrm{P}$ and $\mathrm{E}-\mathrm{iPV}$ and $\mathrm{i}_{\mathrm{EV}}$ planes; the projection center $\mathrm{S}$, which is also the center of the central point projection bundle; the main points of the horizon $\mathrm{i}_{\mathrm{P}}$ and $\mathrm{i}_{\mathrm{E}}$ of planes $\mathrm{P}$ and $\mathrm{E}$; points of the null deformations $\mathrm{C}_{\mathrm{P}}$ and $\mathrm{c}_{\mathrm{E}}$ of planes $\mathrm{P}$ and $\mathrm{E}$; point $\mathrm{V}-$ the basis of the perspective.

The elements listed above allow us to perform the geometric constructions required to get any image of a plane on another.

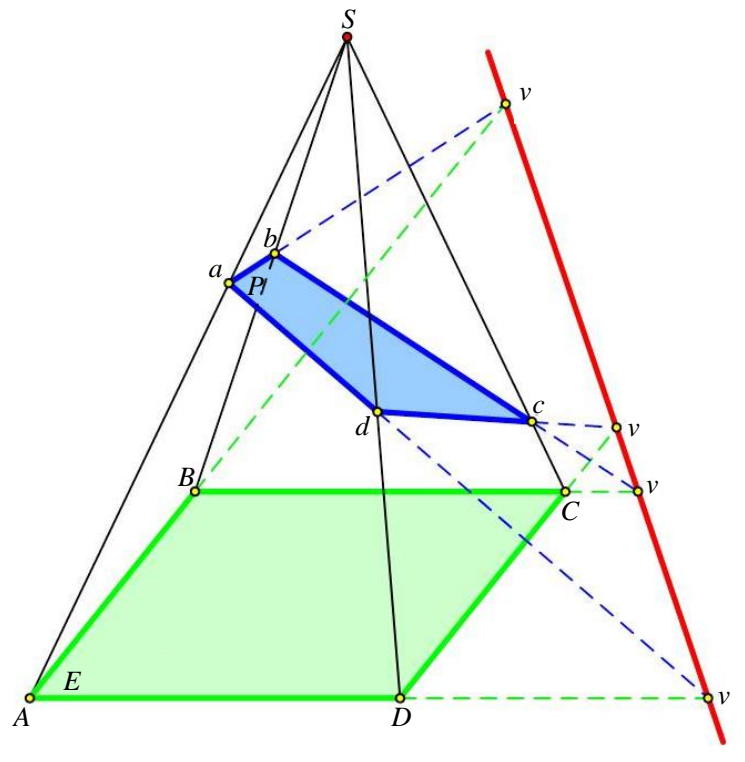

Fig. 24: Corresponding perspective of planes $\mathrm{P}$ and $\mathrm{E}$ in the projection beam with focal point

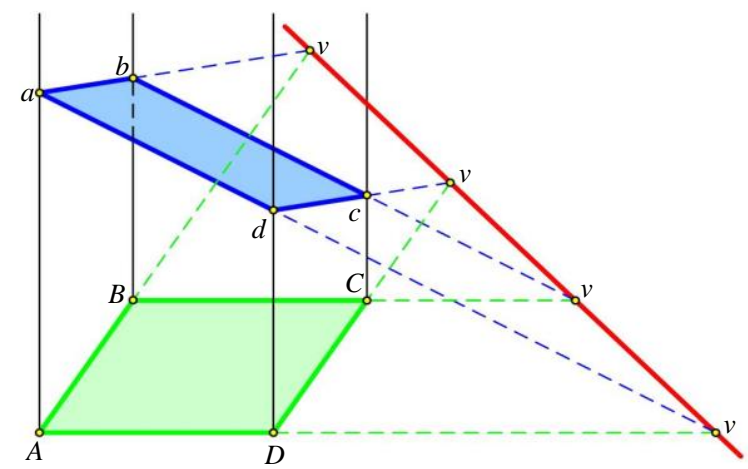

Fig. 25: Correspondence affine (kinship) of planes $P$ and $E$ in the beam of projective rays with improper point

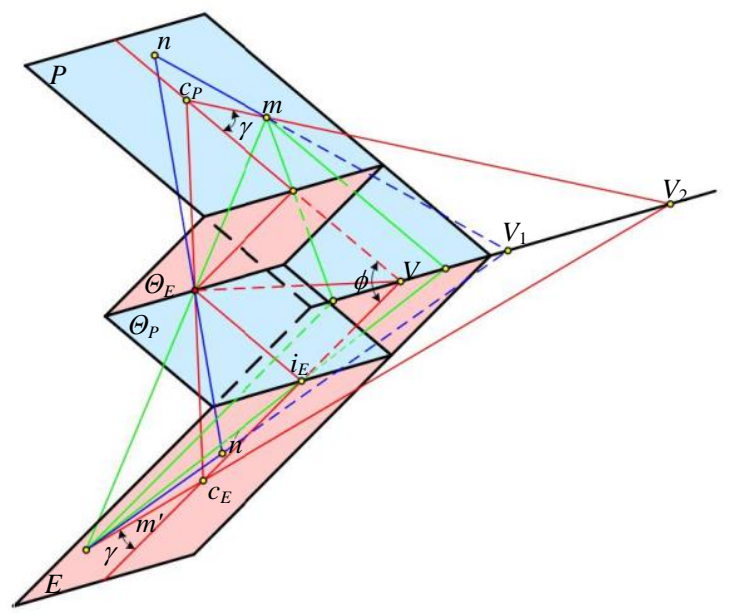

Fig. 26: Constructive elements of the correspondence perspective of the planes 
Point $\mathrm{m}^{\prime}$ can also be built by another method. If the point $\mathrm{m}$ and the radius of deformations $c_{P} c_{E}$ will lead to a plane that extends beyond the drawing will intersect with the axis of the VV perspective, then the trace of this plan in plane $\mathrm{E}$ will pass through the point $c_{E}$ at the intersection with the radius $m_{S}$ we will give the point $m^{\prime}$.

Thus, lines that pass through two points can also be constructed. In this case, by any two points belonging to the straight line and the projection center $S$, a projection plane can be taken up to its intersection with the perspective axis in the $\mathrm{V}_{1}$ point. From the point obtained, the trace of this plane is taken to a point of the straight represented (e.g. $\mathrm{m}^{\prime}$ ), obtained by one of the methods described above. At this point there will also be the second point $\mathrm{n}^{\prime}$, the correspondence of the point $\mathrm{n}$, obtained by leading the projection radius up to its intersection with the projection plane at point $n^{\prime}$ through the initial point $\mathrm{n}$ and projection center $\mathrm{S}$.

\section{Geometrical Conditions of the Perspective} Representation of the Plan in the Standard Version and the Non-Standard Variant

In the standard version of the plan view, the following geometric conditions are met.

For example, the planes P and E (see Fig. 26) are taken out of the reciprocal perspective location and require to relay these planes in another bundle of projection radii with a center point with the center S/ (Fig. 27).

In this Figure are shown the main elements of the perspective planes $\mathrm{P}^{\prime}$ and $\mathrm{E}^{\prime}$ including the plane of the vertical main $\mathrm{S}_{1}^{\prime}{ }_{\mathrm{P}} \mathrm{V}^{\prime}$, where as the placing of each other and switching them invariant perspective $c_{P} i_{P}$ with $c_{P}{ }_{P} i_{P}$ and $i_{P} V$ with $i_{P} V^{\prime}$ ensures the solution of the problem. The angle between planes $\mathrm{P}^{\prime}$ and $\mathrm{E}^{\prime}$ (see Fig. 27) is not equal to the initial angle between planes $\mathrm{P}$ and $\mathrm{E}$ (see Fig. 26). This is of practical importance in photogrammetry because it creates conditions that allow a single optical-mechanical device solving perspective transformation of photograms obtained with different shooting with central mechanism.

The most up-to-date variant of the image perspective transformation, for example the aerographic chart, was examined above. However, in practice, it is often necessary to resort to the non-standard solution of the problem, because the standard solution in concrete cases becomes impossible or unacceptable.

Some options will be examined.

\section{Double and Multiple Representation of Planes in Perspective}

Suppose we have the plan in perspective and we need to get another with pre-established properties. We will call such a representation - double perspective.

The two-way representation of the planes can be encountered in the oriented fields (the fields are oriented where the elements of the perspective are parallel to each other) in two versions: by changing the position of the zero deformation point and keeping its position, ie with loss or preservation its incidence.

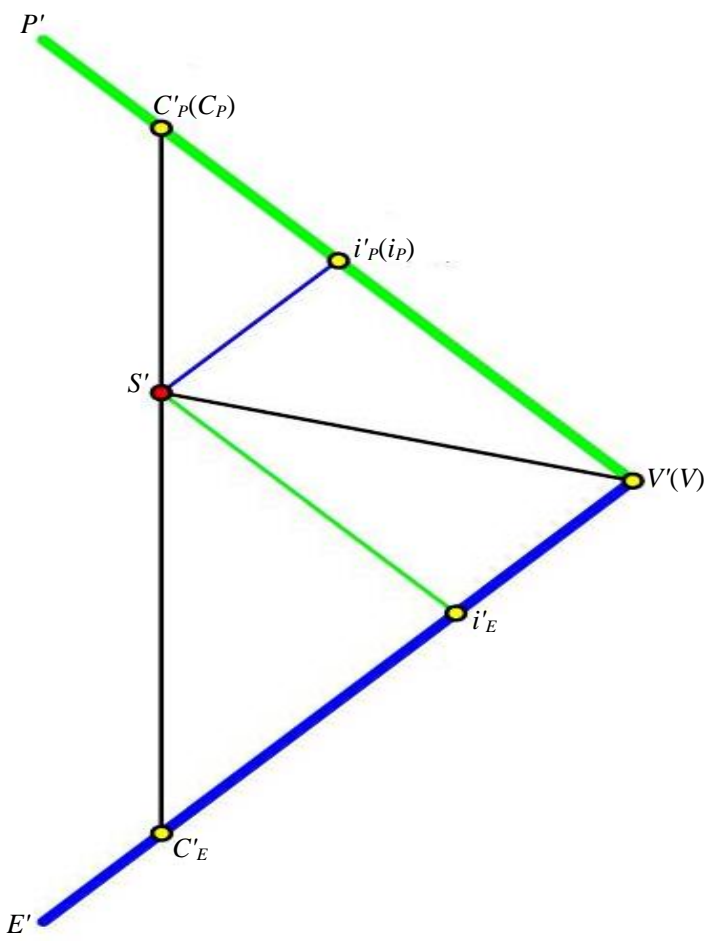

Fig. 27: The standard version of the perspective representation of the plan

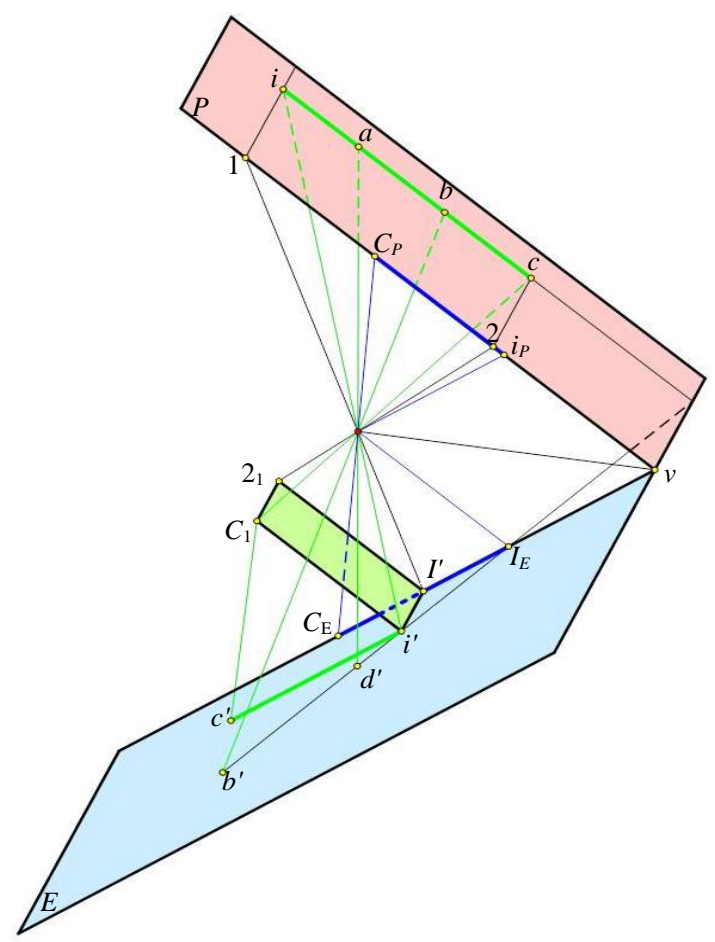

Fig. 28: Transforming the plan with a direct perspective 
The point in plane $\mathrm{E}$, corresponding to point $\mathrm{c}$ in plan $\mathrm{P}$, must belong to the right (iEi)/, but the point will not have the conformity property, which has the point c/does not coincide with the right. There was a loss of incidence (belonging to the right).

With the change of the position of the zero deformation point, i.e. with the loss of incidence in the oriented fields, there may also be two cases. The first case (Fig. 28) is the modification of the perspective plane, since the position of the disappearance line both in the initial plane, located in the plane $\mathrm{P}$ and in the plan transformed into the plane $\mathrm{E}$, remains the same part as that on the original plane. The consecutiveness of the $\mathrm{Ib}$ points on the original plane $\mathrm{P}$ remains the same on the transformed plane E. If we refer to the photogram, the horizon line of the image remains on the same side. We will call such a direct perspective transformation.

The second case (Fig. 29) differs by the fact that the perspective of the plane is inverted, ie the line of disappearance, located on the original image in plane $\mathrm{P}$ in part b (in Fig. 29 - abi), on the image transformed in plan $\mathrm{E}$ is located at the point $a /$ (on the same Figure - b/a/i/). If we refer to the photogram, the horizontal horizon of the image is placed on the opposite side. We will call such a reverse perspective transformation.

The next case is to keep the position of the zero deformation point, better to ensure the incidence of this point, in this case, the belonging of the right, which is the main vertical of the perspective plane. The zero deformation point $\mathrm{c}$ in the transformed plane coincides with the same $\mathrm{cP}$ point of the $\mathrm{P}$ plane. However, the main escape point $\mathrm{i}$ does not coincide with the point $\mathrm{P}$ of the $\mathrm{P}$ plane. As a result, we will get a new perspective in the $\mathrm{E}$ plane with the invariant $\mathrm{c} / \mathrm{i} /$.

Both of these plan view transformation cases can be used with both loss and preservation of the incidence of point $\mathrm{c}$ in the double and multiple transformations of photograms to the first and subsequent transformation steps, except for the last stage when the transformation is performed in the standard version.

And in the non-oriented fields, can also be obtained, the perspective of the transformed plan. In principle, the plan of the new perspective can have any localization of perspective elements. Methods for determining the location of these elements will be further studied in the combined plans (in homology).

In the previous paragraphs, the cases of obtaining the new prospects were examined by transforming the original perspective. All these planes are different by having a pair of lines that are in congruence and pairs of corresponding null deformation points with the conformance property (undeformed angles built at these points). In a transformation perspective with maintaining the zero deformation point position in the image points field (Fig. 30), the transformations take place differently.

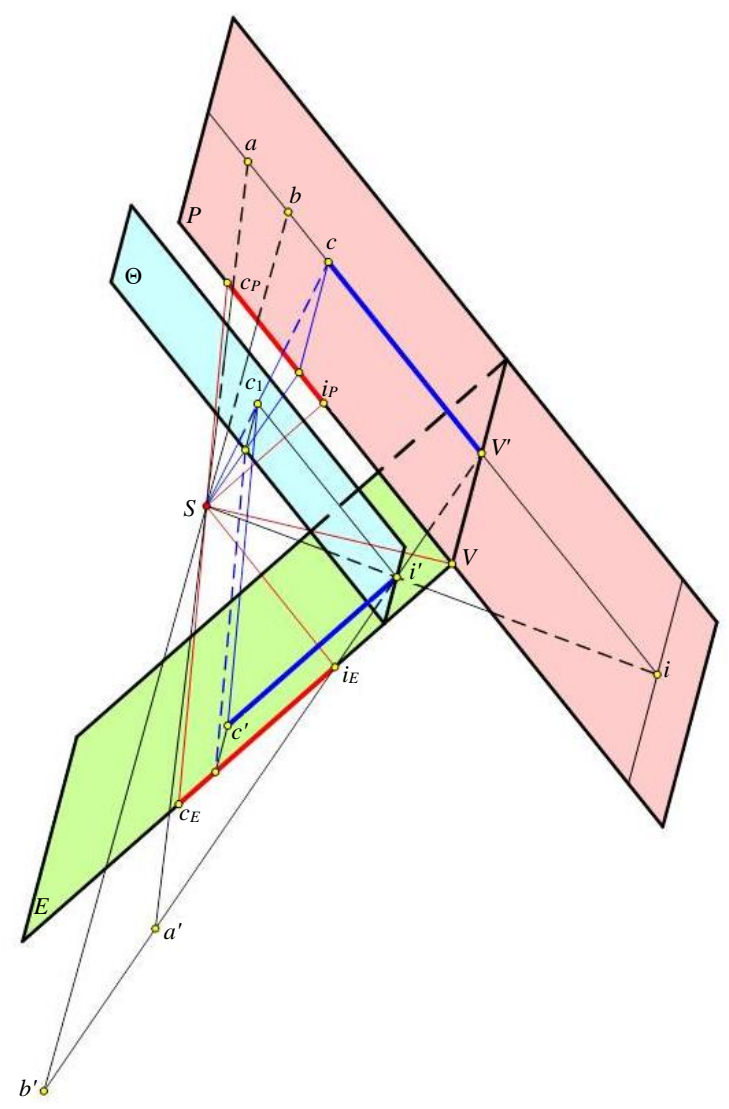

Fig. 29: Transforming the plan with an inverse perspective

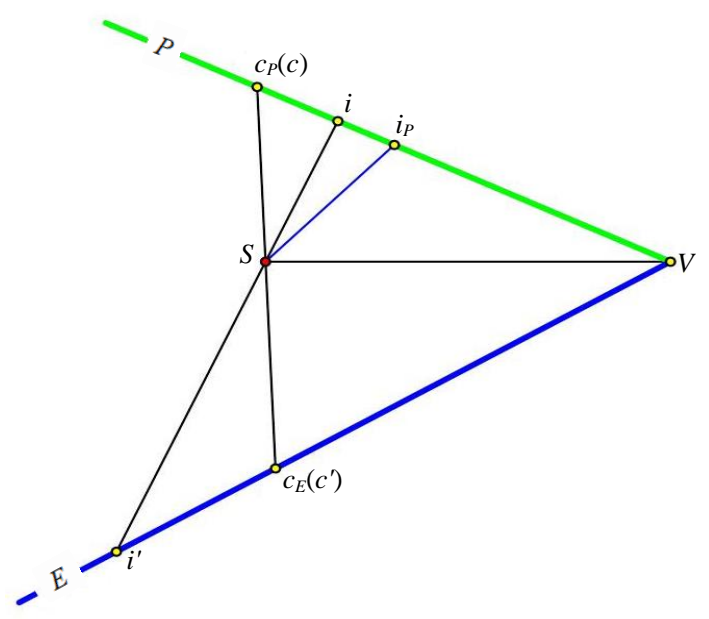

Fig. 30: Transformation perspective with maintaining the zero deformation point position in the image points field

Suppose we have a perspective view of the abed square (Fig. 31) with the invariant of the perspective $c i$ but placed in plane $\mathrm{P}$ and projected in plane $\mathrm{E}$ provided that it combines the line of disappearance of the image with the plane of disappearance of plan $\mathrm{P}$. 


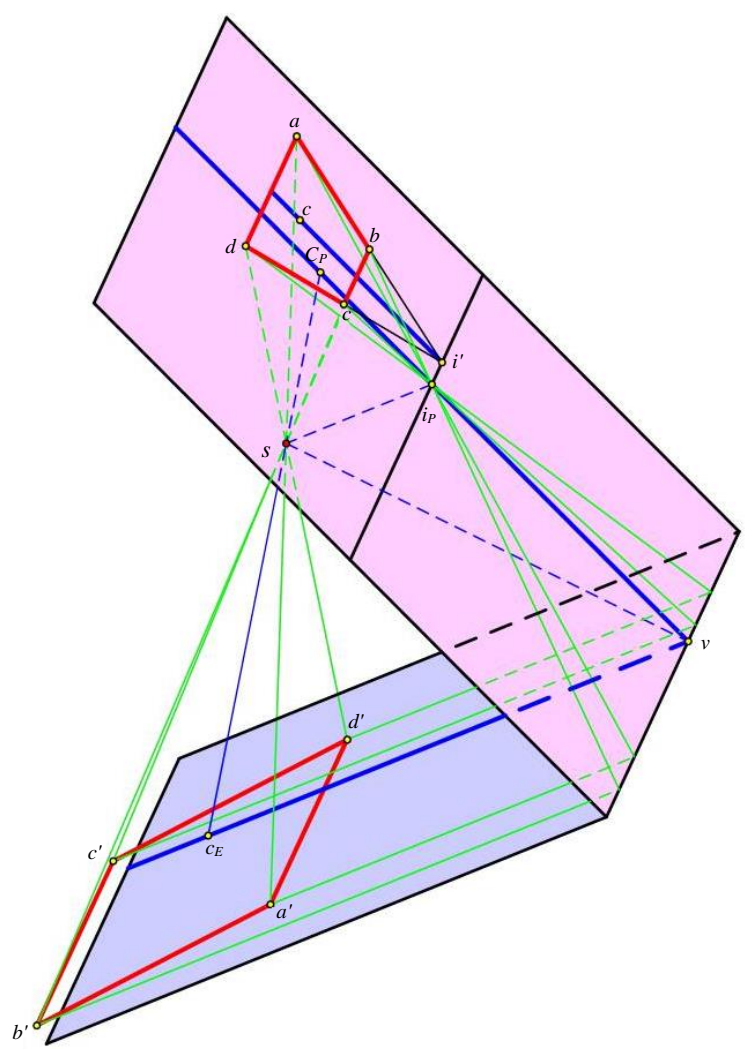

Fig. 31: Obtaining affine correspondence by a perspective transformation of the perspective plane

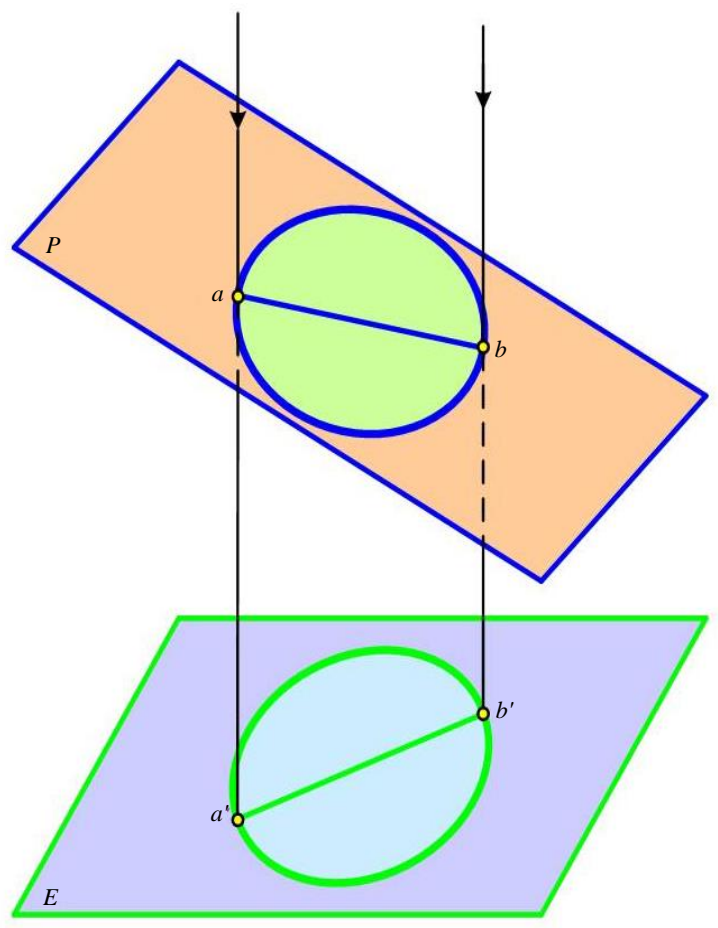

Fig. 32: Representing kinship in the family of parallel straights
As a result the inappropriate elements of the plan in which there was a square represented on the line of disappearance of its image will be projected onto the improper right of plan $\mathrm{E}$.

This means that the parallel sides of the square will again be represented in the parallel E plane.

However, the angles between the sides will be deformed due to the fact that the zero point of the image $\mathrm{c}$ is not combined with the similar point $c_{P}$ of the plane $P$ and the square image in the plane $E$ will be a parallelogram $a^{\prime} b^{\prime} e^{\prime} d^{\prime}$. In the case of overlapping in plane $\mathrm{P}$ outside the line of disappearance and the main vertices but also $c i$ and $c_{P} i_{P}$, the transformed square image in plane $\mathrm{E}$ will become a rectangle, elongated or compressed along the main vertex $c_{E} V$.

Thus, a parallelogram, or its particular case a rectangle, are the corresponding Figures of a square. It is clear that if instead of the image of a square we take the image of the perspective of any of the drawing or the image and carry out with it the transformations examined, we will therefore obtain the representation of the image of the image.

In general correspondence there is no pair of straight lines that are in congruence and the point of null deformations turns into an improper point.

The standard view representation makes it possible to obtain three special cases of blue plane correspondence: kernel, conformance and congruence, but excludes obtaining the corresponding blue plane correspondence plan as discussed above.

Mutual correspondence is obtained when the projection center becomes improper and the projection rays parallel to each other (Fig. 32).

This correspondence has a pair of straight lines $a b$ and $\mathrm{a} / \mathrm{b} / \mathrm{which}$ are in congruence.

\section{Deforming the Image at the Points of the Projective Plane}

Corresponding correspondence between planes $\mathrm{P}$ and E (Fig. 24) can be obtained when these planes are parallel to one another. Then the perspective axis (double right $\mathrm{VV}$ ) becomes improper and all relevant points of planes $\mathrm{P}$ and $\mathrm{E}$ obtain the compliance property.

Congruent correspondence is a particular case of conforming correspondence when two overlapping planes coincide with all their points. Such a plan will become double, consisting of double points and double lines.

\section{Projective Representation of Central Point Bundles}

Radiation and center-point planes, as well as centralbeam beams, can be in correlation and perspective.

For simplicity, we assume that we have a projection plane $\mathrm{P}$ (Fig. 33) and two bundles with projection centers $\mathrm{S}$ and $\mathrm{S} /$, correlated perspective. These bundles will be in projective correspondence, because at the intersection of 
$\mathrm{S} 1$ and $\mathrm{S} / 1$ and planes (S25 and $\mathrm{S} / 25$ ) there will be points and straight points located in the same plan $P$.

If the plane $\mathrm{P}$ is layered in two $\mathrm{P}$ and $\mathrm{P}^{\prime}$ which are arranged in space together with random bundles (Fig. 34 ) and then take any pair of corresponding rays $\mathrm{S} 2$ and $\mathrm{S} / 2$ as the axes of the plane bundles, obtaining two projective correspondent bundles, then the intersection of the corresponding planes in the bundles (S25 and $S^{\prime} 2^{\prime} 5^{\prime}, S 23$ şi $S^{\prime} 2^{\prime} 3^{\prime} \ldots$ ) will give us the lines I ... m etc., which form the ruled surfaces of the second order. This surface will also pass through the right joining the centers of the bundles $S$ and $S^{\prime}$ and its corresponding bundles will be in perspective but correlative.

As axes of planar pairs of planes which are in a projective correspondence and form second-order ruled surfaces, any pair of straight lines taken through the projection centers $\mathrm{S}$ and $\mathrm{S}^{\prime}$ and the corresponding points $\mathrm{i}$ and $\mathrm{i}^{\prime}\left(i=1,3 \ldots, i^{\prime}=1^{\prime}, 3^{\prime} \ldots\right)$ of planes $\mathrm{P}$ and $\mathrm{P}^{\prime}$ obtaining new ruled surfaces. So in the following way we can get an infinity of ruled surfaces of the second order, passing through the right SS/, which is their common line.

\section{Perspective Representation in Combined Plans (Homology)}

Before proceeding to the analysis of perspective views in the combined planes we will examine the conditions for obtaining the combined planes.

Figure 35 from the point of view of the linear perspective are presented the conditions of perspective transformation of the square image abcd, located in the plane $\mathrm{P}$, in its $\mathrm{ABCD}$ conformation, obtained in the $\mathrm{T}$ plane by means of the projection center $\mathrm{S}$. In the same plan $\mathrm{T}$ but with the help of the centers projection S1 and S2, located in the plane of the horizon $\mathrm{H}$, were obtained two blue representations of this square A1B1C1D1-rectangle and A2B2C2D2-paralelogram, which undergo a clear affinity change compared to the A1B1C1D1 rectangle.

These and other perspectives transformations can also be made in the combined planes if the planes $\mathrm{P}$ and $\mathrm{T}$ are rotatably pivoted around the axes perpendicular to the vertical plane of the iSJV main and pass through the points $i$ and $V$ (Figs. 35 and 36).

In Fig. 36 by the abed letters is the perspective image of the ABED square with the center of the $S$ perspective (the zero deformation point c), the line of the VV/and the disappearance line ii/. When changing the position of the center of perspective $S /(c /)$, the square image turned into a parallelogram $\mathrm{A} / \mathrm{B} / \mathrm{E} / \mathrm{D} /$, corresponding to the square ABED.

In photogrammetry, it is usually necessary to perform the projective transformations in order to obtain sufficiently precise the geometric shape of the represented object, or the similarity of the object - its diminished geometric model.

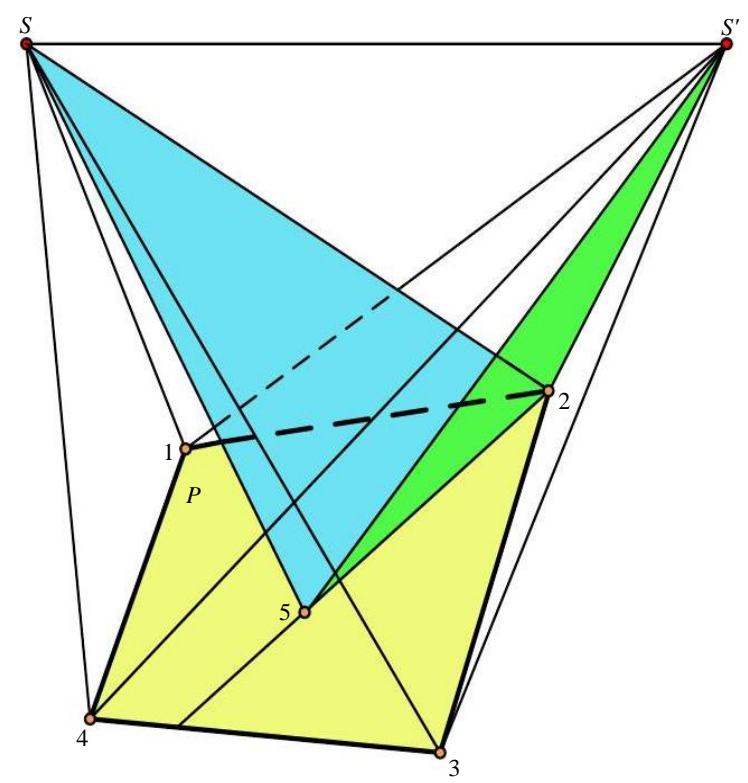

Fig. 33: Two core projection co-axes, supported by a plan that corresponds to them, are in perspective correspondence

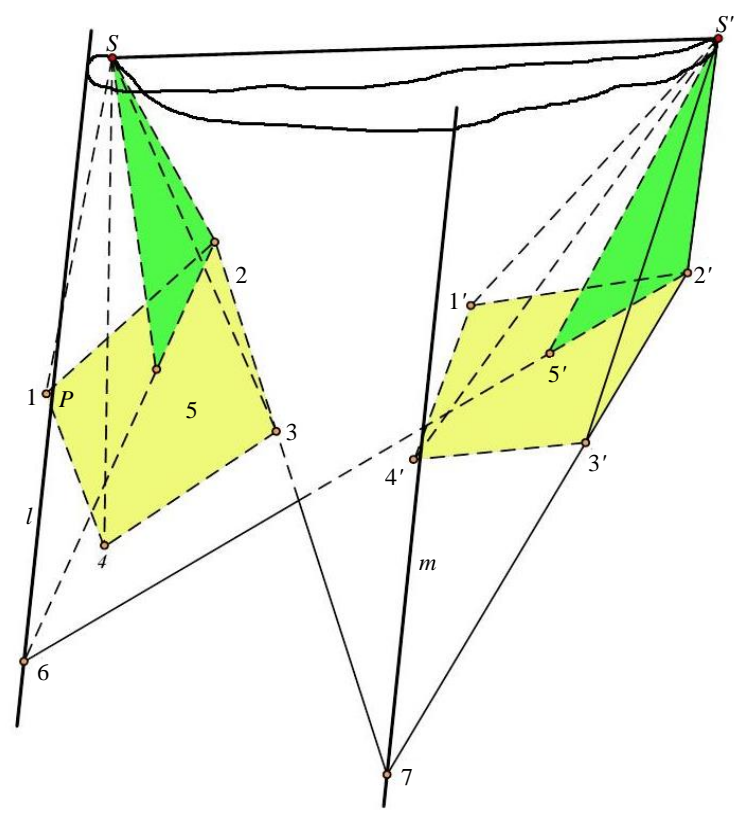

Fig. 34: Two projective bundles corresponding to central points, arbitrarily located one at the other, at the intersection of the corresponding plane beams, form the ruled surfaces of the second order

When using the optic, mechanical and mechanical methods of projective image transformation, as mentioned, there are frequent situations where a single ordinary transformation is not sufficient and we need to perform two or more. 


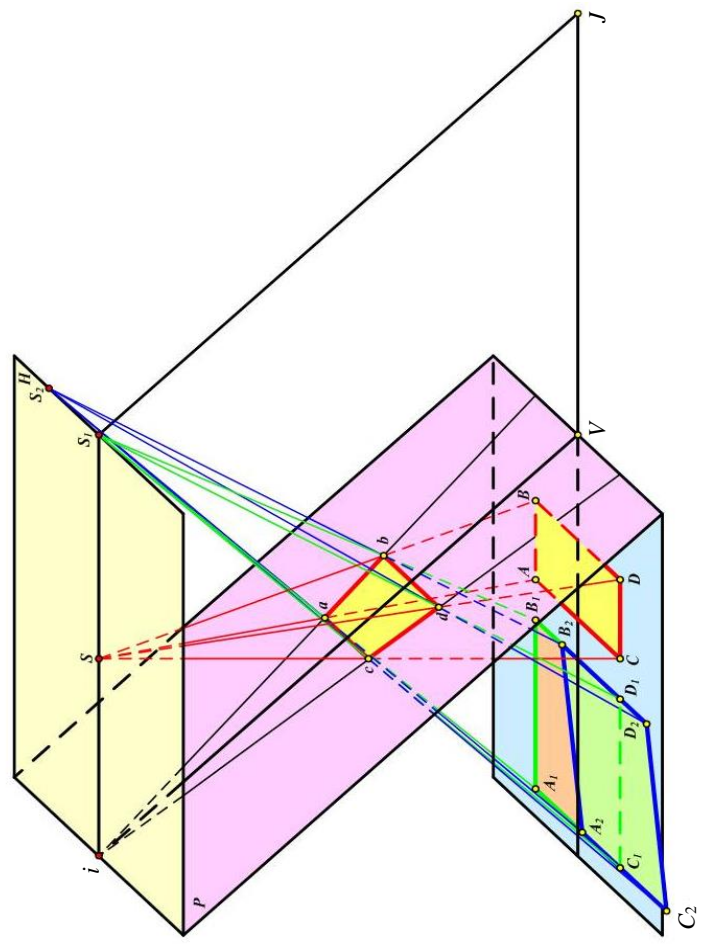

Fig. 35: Linear Perspective in Variants: conform to $A B C D$ and affine A1B1C1D1 (A2B2C2D2)

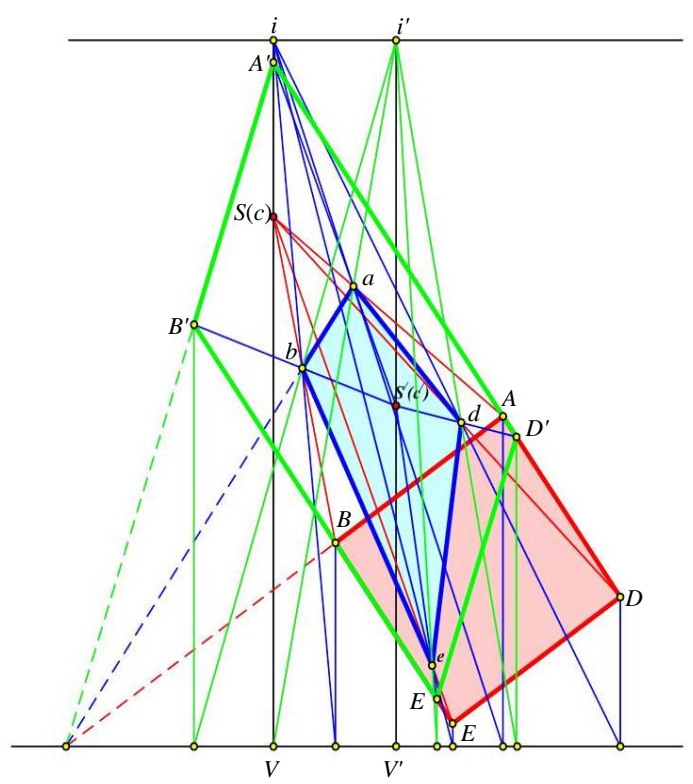

Fig. 36: Perspective representing in combined planes

In these cases, it is of particular importance to place the elements of the perspective of the image transformed to the image field of work. We will examine several cases of perspective transformation of the projective plan in order to obtain its changes with the transformed perspective elements of the set.

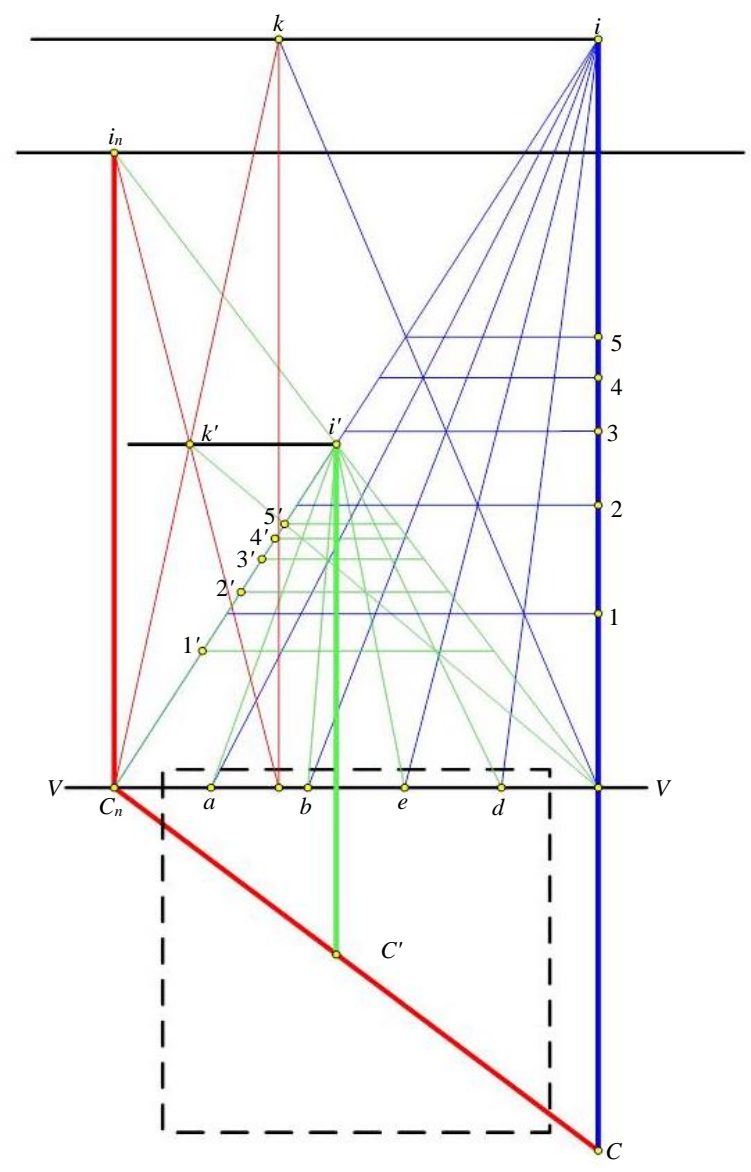

Fig. 37: Getting the perspective field transformed with the new invariant c'i' with the direct perspective

The Homologous Transformation of the Perspective Plane with the Change of the Perspective Invariant Position in its Field

In dual and multiple transformations of the perspective plane, a great deal of importance has not only the distortion of the image in it, but also the position of the elements of the perspective towards the image. In the practice of the optical-mechanical transformation of the perspective plane it is important that as a result of this main vertical transformation it passes approximately through the center of the image and the point of the null deformations is in the middle of it. Such a lightweight perspective plane turns into confirmation, which is usually required, for example, in the optical-mechanical transformation of aerofotograms for cartographic purposes.

\section{Double Perspective in Homology}

First, we will examine the dual perspective in the targeted fields. For this purpose, we will introduce the notion of fields of perspective planes, their characteristics and their mutual orientation conditions. Under the field 
names of the planes of perspective, we will understand the elements of the perspective that characterize them: the main vertices, the null deformation points and the main points of flight, because their position on the image often depends on the possibility of transforming the perspective plane into a plan. We will also agree to divide the fields into initial (passive), transformable (active) and results that are obtained as a result of transformations.

Let us assume that in the perspective plane with the invariant of the original perspective (Fig. 37) the image is located in a marked area by dotted line and its transformation perspective in conformation to the phototransformer can only be assured if the point of deformations null $\mathrm{c}^{\prime}$ will be at the center of the image. To do this, we make the necessary transformations.

\section{Generally Homologous Transformation of Perspective Plan}

We chose in Fig. 37 the transformation field with the inverse of the line $c_{n} i_{n}$, the basis of the VV perspective and the transformation of the initial field into the resulting $c^{\prime} i^{\prime}$. In this transformation, we first get the point $i^{\prime}$ through a simple construction.

The obtained image of $V i_{n}$ of the right $c i$, but in the transformed field $c_{n} i_{n}$ and the union of points $c n$ with the point $i$ and give us two straight lines.

At the intersection of these straight lines there is the new main escape point $i^{\prime}$ or the resulting field. Since the initial ci and $c_{n} i_{n}$ transformable fields are mutually oriented, then as a result of the transformation of the initial field, the new transformed field $c^{\prime} i^{\prime}$ did not change the orientation, because only the redistribution of the horizontal: $1,2,3,4,5$ in the initial field, $1^{\prime}, 2^{\prime}, 3^{\prime}, 4^{\prime}, 5^{\prime}$ - transformable. With letters a, b, $\mathrm{e}, \mathrm{d}$, the double points of intersection of the corresponding straight lines in the ray beams with the centers in the main escape points $i$ and $i^{\prime}$ respectively are noted.

The null deformation point of the transformable field $\mathrm{c}^{\prime}$ is at the intersection of the new main vertex that passes through the primary $i^{\prime}$ or right-point escape points connecting the null deformation points of the initial field $\mathrm{c}$ and the transformable field $c_{n}$ because this line retains its orientation angular to all three main vertices, combined in a plane of perspective fields.

The dotted line in Fig. 37 shows the boundaries of the image, at the center of which the new zero deformation point was obtained $\mathrm{c}^{\prime}$.

Transforming the perspective perspective plane can also be performed with the reverse perspective (Fig. 38). It is easy to notice that in this case the initial ci and transformable fields $c_{n} i_{n}$ are mutually antitetic oriented.

As a result of the construction, performed analogously to the previous case with direct perspective, the new field versus $c^{\prime} i^{\prime}$ the original one has the opposite orientation.

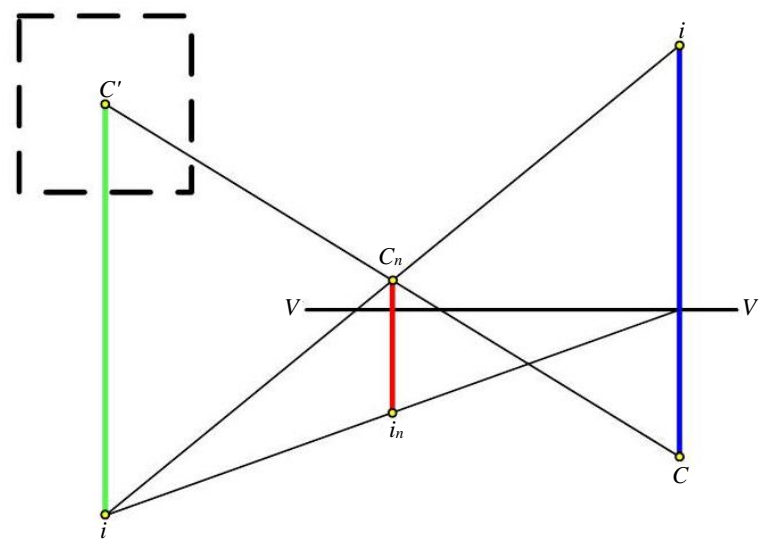

Fig. 38: Getting the perspective field transformed with the new invariant $c^{\prime} i$ ' with the inverse perspective

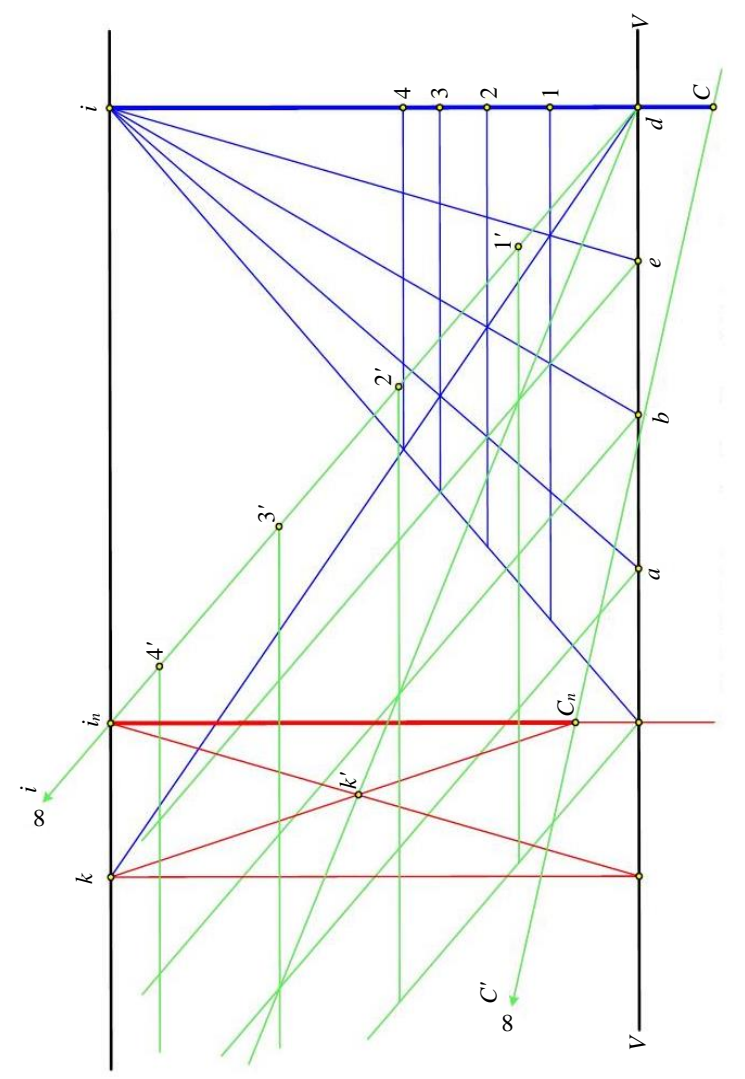

Fig. 39: The condition of obtaining the transformed affine field in the combined planes

Therefore, with respect to the image shown in Fig. 39 through the dotted line, the line of disappearance is on the opposite side to the original one. And on the drawing, the close plane in the original field turns away from the transformable field and vice versa.

If the transformed and transformable field disappear line coincides (Fig. 39), the resulting field is affine. The main 
point of escape and/or the point of deformations c/is projected to infinity, becomes inappropriate, improper becomes the main vertical c/i/of the resulting field. The rectangles in the corresponding plane, represented as quadrants in the transformable perspective field at the intersection of the ray of beam abed with the horizontal 1,2, 3,4 in the resulting field are parallelogram formed at the intersection of the parallel lines passing through the abed points and 1/2/,3), 4).

The resulting field parallels can be obtained by using the diagonal $\mathrm{dk}$ trapezes of the initial field. From that point $\mathrm{k} /$, obtained with the points $\mathrm{cn}$ and in and the homology axis $\mathrm{VV}$, allowed us to obtain the $\mathrm{dk} /$ of this diagonal in the resulting field.

Further, the right $\mathrm{dk} /$ at the intersection with the parallel family of lines, passing through the abed points, in turn, allowed us to obtain a family of straight lines parallel to the VV axis and passing through points 1,2,3/, 4/.

Thus, the projective-bay plane formed by the projectivehomologous transformation of the perspective plane is distinguished by the fact that it does not have in its main vertical field, the accompanying points of the main vertical, the main point of escape and the points of deformation.

In the more general perspective perspective transformation of the plan, for example, overlaying the disappearance line of the transformable plane (Fig. 40) with the vertical vertex of the initial plane, the abed quadrilateral is the square image of the plan according to the new anbnendn quadrangle of the transformed plan.

The problem of determining the position of the perspective field elements of the resulting field appears. For this purpose, we will find the position of the disappearance line of this field and the zero deformation point, with which we will also get the main vertical.

One of the points of escape of parallel lines in the initial field and the plane according to is the point in, the second point of escape of the right-hand sides andn and bnen is the point i1, by which we will trace the line of disappearance ini1 of the final field, because the anbendend square is a double perspective view of the square of the corresponding plane. If we now construct a right angle so that its sides pass through the points in and il and then we will point its tip and draw a circle through three points, then one can argue that the point of zero deformations will be placed on it.

When using the right angle, the inil segment is the diameter of the circle. Therefore, it is enough to find the middle of the ini1 segment and by taking the center of the circle we draw this circle. To determine the exact position of the null deformation point of the final field, it is sufficient to obtain the second circle. To this end, we will find the escape points of straight families parallel to the diagonals of the square, represented by the anen and bndn straight lines. These points are i2 and i3, through which we draw the second circle.

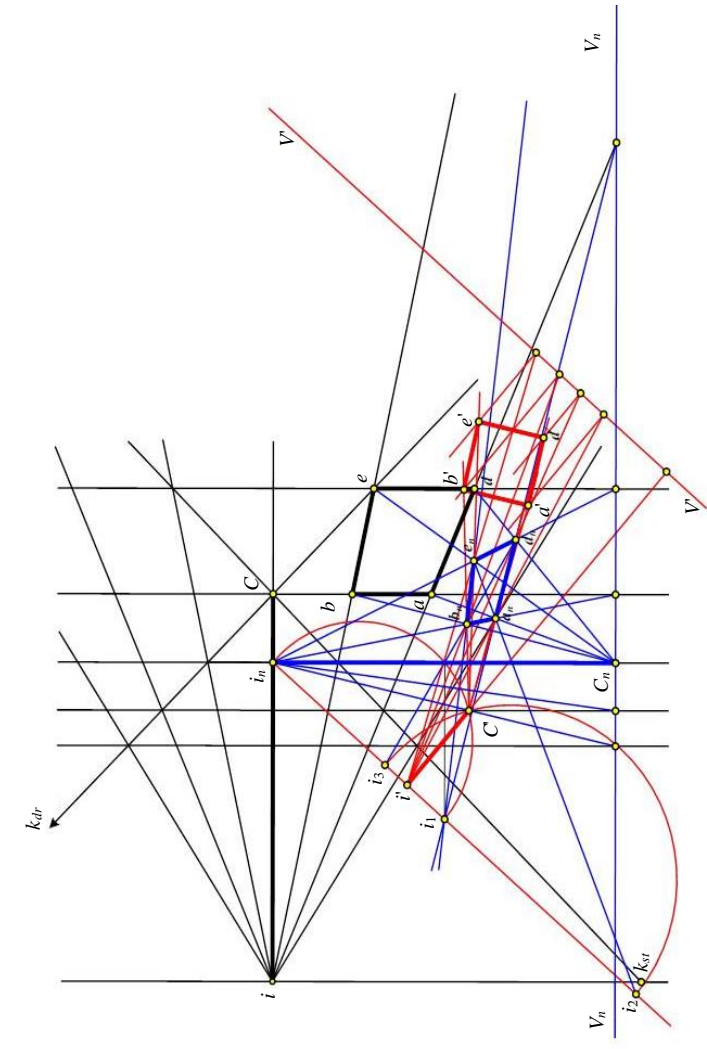

Fig. 40: The general case of perspective transformation of the perspective plane in combined planes

At the intersection of two circles and we will get the searched point c/. Descending from this point perpendicular to the extinction line ini1, we will get the main escape and/or the main vertical point of the resulting field $\mathrm{c} / \mathrm{i} /$.

In order to verify the correctness of the executed constructions, we will choose the baseline of the V/V perspective line in the plane of the plan and we will convert the square anbendend in the square $\mathrm{a} / \mathrm{b} / \mathrm{e} / \mathrm{d} / \mathrm{similar}$ to the square of the corresponding plane by means of the points $\mathrm{i} / \mathrm{c} /$.

In the general case in the plan according to the figure does not necessarily have to be square. It is sufficient to have any triangles (or parallelogram) with two pairs of parallel sides, marked, for example, by the points in their vertices.

After a series of perspective transformations and blueberries, they will also be represented by triangles or quadrilateral.

\section{Perspective Space Representation on the Plan}

In view of the perspective view of the three-dimensional space on the plane (Fig. 41) outside the special points examined above and the main vertical iVn there are still two important points, the nadir point $\mathrm{n}$ and the main point $\mathrm{o}$. 


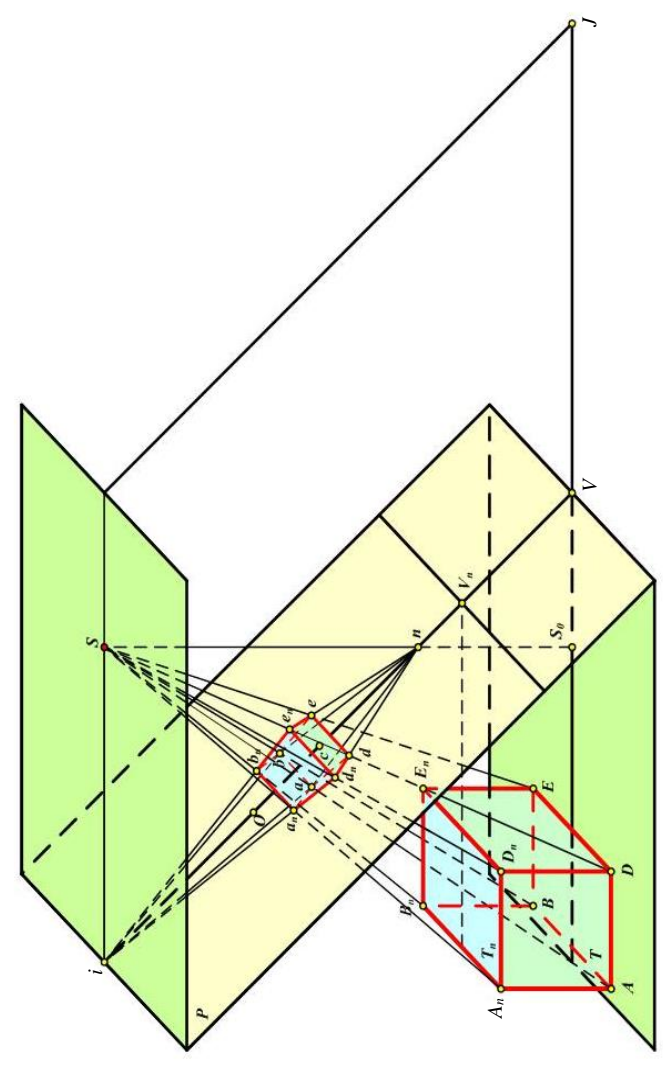

Fig. 41: Representing the perspective of the space $T \ldots T_{n}$ in plan $P$

The nadir point is distinguished by the fact that it is the point of escape of the image of all vertical lines towards the horizontal planes $\mathrm{T}$ and $\mathrm{Tn}$. these lines are aan, bbn, een, ddn, which represents the image of prism edges AAn, $\mathrm{BBn}, \mathrm{EEn}, \mathrm{DDn}$. The lower edges of ABED and the upper $A n B n E n D n$ of the prism or represented in plane $P$ are trapezoidal abed and anbnendn, the opposing sides of which ad and ben andn and bnen are converging to the main point of escape and the image of the prism edges perpendicular to the plane of the vertical vertex iVJ or represented parallel to one another and perpendicular to the vertical vertical iV.

From Fig. 41 also shows that in the representation of the space between the planes $\mathrm{T}$ and $\mathrm{Tn}$, each of the planes parallel to them is represented separately, because they have a perspective "sa" axis passing through the point $\mathrm{Vi}$, located between the points $\mathrm{V}$ and $\mathrm{Vn}$. However, all the other elements of the P-plane, the line of disappearance passing through the i-point, the vertical vertex $\mathrm{iV}$, the zero deformation point $\mathrm{c}$, the nadir point $\mathrm{n}$ and the principal point $\mathrm{o}$ - for all the horizontal planes are the same. The last point, the main one, is the foot of the perpendicularly lowered from the projection center $\mathrm{S}$ on the plane $\mathrm{P}$ and is the origin of the rectangular coordinate system in this plane for solving photogrammetric problems.

If the projection center $S$ will be moved to the horizontal plane $\mathrm{H}$ elsewhere and we will project the abedanbnendn figure on the corresponding $T$ and $T_{n}$ planes, we will get an inclined parallelipiped.

Under the name of a projective plane, as is customary, we refer to the plane consisting of points and lines and has an improper right if we consider the abstract image or the drawing of this plane, considering it to consist only of elementary constructive elements. If we introduce straight lines and special points into the plane, then it will be possible to distinguish the particular cases of the projective plans.

For example, if the projection plane consists of points and distributed lines absolutely uniform along it, as mentioned above, we will consider it conforming, absolutely symmetrical and has no special points and lines, except the line improperly mentioned above. On this plane, all points have the property of the zero deformation point, which is the property of the compliance.

If the projective plan has a single point, then it must have the main point of escape, the main vertical and the line of disappearance. Such a plan is perspective and has axial symmetry over the main vertical. The points and lines on it to the conform plane (as its perspective view) are unevenly distributed. The closer they are to the disappearance line, the more dense and dense they are.

If the projective plane has two axes of symmetry reciprocally perpendicular and has no deformation points in its own field, then it is affine and the symmetry axes are called the main conjugate diameters. For all directions, the structural elements of the blueprint are uniformly located.

In two main symmetry directions the density of the structural elements is distributed differently, but it is different with a constant value.

Thus, all projective plans are divided into two classes: perspectives and blueberries. Other types of projective planes in collinearity do not exist. All the others, listed earlier, are their particular cases.

In the representation of space on the plane, as mentioned above, plane views appear with a special location of the nadir point. The nadir point is the geometric space of the straight line of the image, perpendicular to the original plane, represented by the center - point beams on the perspective plane. The perspective plane of the spatial object differs from the perspective plane of the plan object by the fact that in the representation of the curved elements of the spatial object, its plane curves, obtained as a result of the sectioning of the space with the projective plane beam, will be represented on the straight line of the perspective. Therefore, the perspective plane of the spatial object in relation to it is only partially collinear, because a right in the field will be represented as a straight and the curve can also be a straight line if it is in one of the planes of the beam with central point, which projects space on the plane. 
The perspective plane of the spatial object also has axial symmetry.

Any collinear transformation of the perspective plane, except the conformation, leads to violation of the design conditions of the image transformed into the spatial image, because the nadir point does not hit the required spot, which is determined by the central projection.

The beam of projective rays in this case should have a different geometric construction, different from the geometric construction of the central point projection beam.

The plan of projective transformation of the plan of the spatial object perspective, as mentioned, is called projective. This plan generally does not have a certain symmetry due to the fact that the nadir point does not coincide with the main vertical.

In the photogrammetric processing of the image, transforming the plan view of the center projection perspective into the projection may occur regardless of the specialist's desire, for example, to obtain an enlarged or reduced image of the microfilms, without accurately respecting the shooting and reproduction conditions, deformation of the image of the substrate, especially nonelongated on the two mutually perpendicular directions, etc. In these cases, the theory, methods and tools used for the usual projection of central projection, for stereo processing and optometric transformation of deformed image are less useful and can lead to significant loss in precision. In transforming these images, it is important to know the new position on them for the correct introduction of corrections for the influence of the terrain. The transformation of such images can be accomplished by any of the known methods and from the point of view of the theory, without any loss of precision, since such a picture remains collinear in relation to any flat surface of the terrain.

\section{Project Representation of the Plan with the Complex Projects of the Projects More Completed Through the Central Point}

It is known that the concept of "beam" of straight rays passing through a point only refers to the central point version. However, with the development of new shooting tools in the aerospace industry, it is necessary to extend this concept and be assigned to the cases, mostly projectivecholarine and the second order of representation. In these cases, an abstract-constructive representation of geometric lines of the image that joins the corresponding points of the plane or the space of the objects with the plane (space) on which they are represented is also possible. Unlike the central point beam in a generalized way, the geometric location of the intersection of the projection radii may be straight or even flat.

The geometrically constructive representation of the beam of projective rays that unite the same points in space and their plane of representation and still the space of representation, gives us the opportunity to obtain the most accurate image of an abstract phenomenon that is relatively easy to pass in the future in a mathematical language.

The general notion of stack bundles, projection rays can be formulated, for example, in the following way.

A bundle of projective rays - is an abstract geometric construction of lines (rays) that connect points with the same name in space and plane of the image.

The geometric basis of the bundle construction is one of its lines, which in itself represents the geometric location of the intersection of the projection radii to the representation of the plane plane plane and the individual planes, which is an assembly of individual lines in itself, to the representation of the space of the objects on the plane space) of the image.

The rays of the complex bundles unite between them the corresponding points of the objects and their image and the coplanar plane (plane) and the ruled surfaces of the second order unite between them the right lines (the straight lines and the curves of the second order) of the objects and their images.

\section{The Bi-Linear Projection Beam}

The basis for almost all intricate projective ray beams is the bilinear beam. The most obvious bilinear beam can be shown in the plane representation of plane $\mathrm{P}$ on plane E (Fig. 42) or vice versa, plane E on plane P. The general principle of designing points from one plane to another can be defined in the following way.

The bilinear beam (Fig. 43) with the as and a/s directories, as well as the center-point beam, can be represented on the projection plane $\mathrm{P}$.

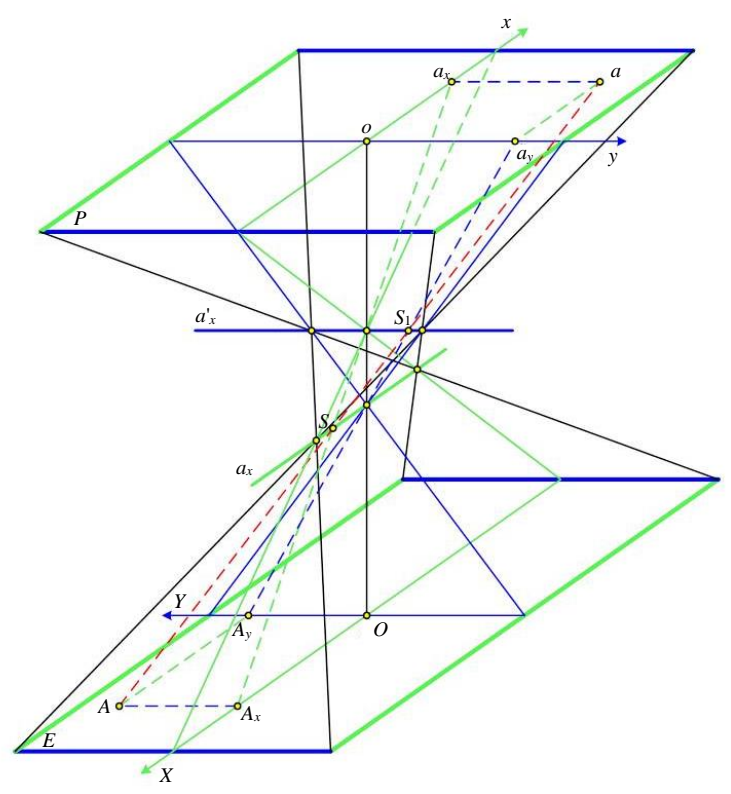

Fig. 42: Representation of the affine general position plan by the bi-linear beam of projective rays 


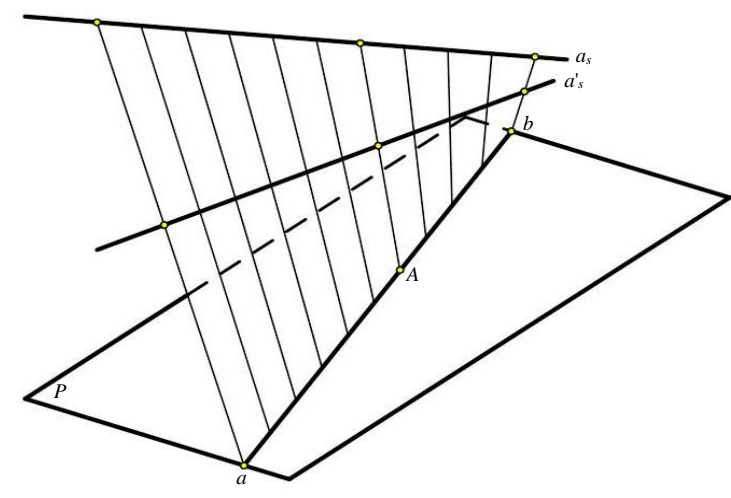

Fig. 43: Representation of the bilinear beam on the projective plane

In this case, the projection rays of the beam will correspond to points $\mathrm{A}$ and the planes and surfaces of the second order, passing through the directories as and a/s straight lines $a b$. In a particular case, when the right of the projection plane becomes coplanar to one of the beam directories, the corresponding second-order surface turns into a plan.

Imagines the bilinear beam in the form of two plane bundles with the axes a and $\mathrm{a} / \mathrm{s}$. Through any point in Plan $\mathrm{P}$ we can plot the planes a/sa and so, which in plan $\mathrm{E}$ will give us the traces of AAX and AAY. The intersection of these planes will give us the projective radius $\mathrm{Aa}$, which intersects the as and a/s lines in $\mathrm{S}$ and $\mathrm{S} 1$. The lines, parallel to the ox, oy and OX, OY coordinates and the as and $\mathrm{a} / \mathrm{s}$ beam directories, are planed with planes and all other lines - with second order ruled surfaces. In this case, straight rows, such as the diagonal of the oaxaay quadrangle and two axes of plane beams as a/s, allow them to draw with their help a single ruled surface of the second order, which in its extension will intersect plan $\mathrm{E}$ after the right OA. This surface is a hyperbolic paraboloid because the oa, a, a/s, OA and all other directories that form a single series will be parallel to a single plane and all projection rays belonging to another generating series will be parallel to another plane, which is not parallel and does not coincide with the first one.

One will call the axes of the planes of the plane as and $\mathrm{a} / \mathrm{s}$ of the bilinear beam and the straight lines $\alpha \mathrm{A}$ of the plane $\mathrm{a} / \mathrm{a}$, as well as the second order ruled surfaces, passing through oa, as, a/s, OA - rays projection, planes and rudimentary surfaces of the second order, respectively.

\section{Projective Representation of the Plan Using the Bilinear Beam of Projective Rays}

\section{Representation of the Bilinear Beam on the Projective Plane}

Unlike the blue representation of planes on the other, through the bilinear beam of projective rays, its directories do not have to be parallel to plan $\mathrm{P}$ and at their extension they will intersect it in points $V$ and $V /$ (Fig. 44a). In particular cases one of the directories, eg as (Fig. 44b) may be parallel to plan $\mathrm{P}$ (intersect the plane at the wrong point) and two a/s - to intersect it at point V/as mentioned, both directories (Fig. 44c) may be parallel to the projection plane. The directories parallel to both planes will be called special ones.

In addition, the bilinear beam can also be transformed into a monolinear (Fig. 45a and b) with the director of a, which intersects with the plane Pin point $V$ (Fig. 45a), or at the wrong point (Fig. 45b).

General Principles of Projective Transformations of the Plan through the Bilinear Beam of Projective Rays

In the general case, when two corresponding projective planes $\mathrm{P}$ and $\mathrm{P} /$ (Fig. 46) intersect after the right VV/and the points $\mathrm{V}$ and $\mathrm{V} /$ are double and at the same time $\mathrm{VV}$ crossing points/with bilinear beam directories as and a/s, the transformation of the right abcd to right $\mathrm{a} / \mathrm{b} / \mathrm{c} / \mathrm{d} / \mathrm{is}$ done with the traces $\mathrm{Va}, \mathrm{Vb} \ldots \mathrm{V} / \mathrm{c} /, \mathrm{V} / \mathrm{d} /$ of the projective planes $(\mathrm{aVa} /$.) of the two beams with the axes a and $\mathrm{a} / \mathrm{s}$.
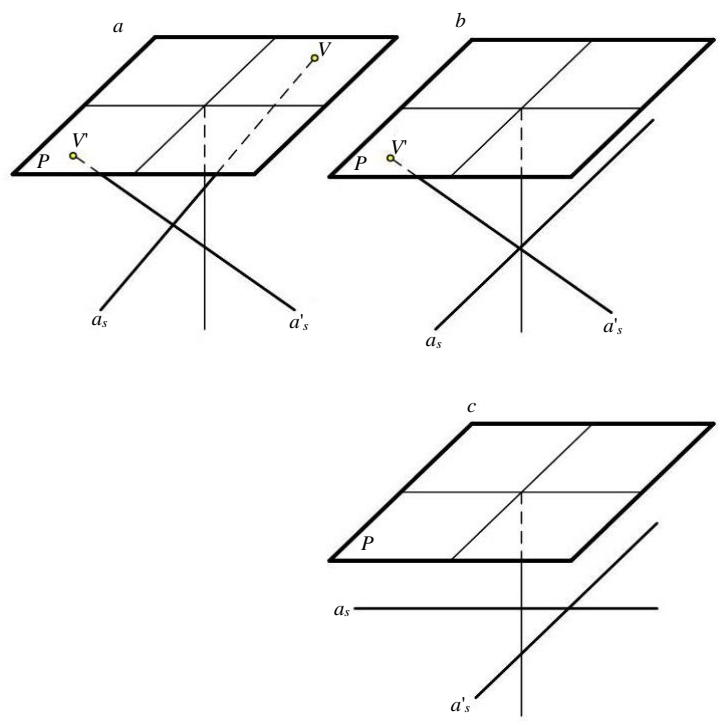

Fig. 44: Variants of the location of the directories a and a' with the object of the projection plane $\mathrm{P}$

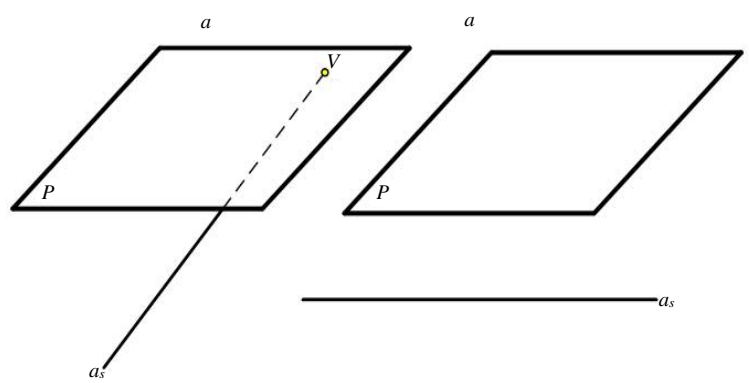

Fig. 45: Variants of the location of the director line a towards the projective plane $\mathrm{P}$ 


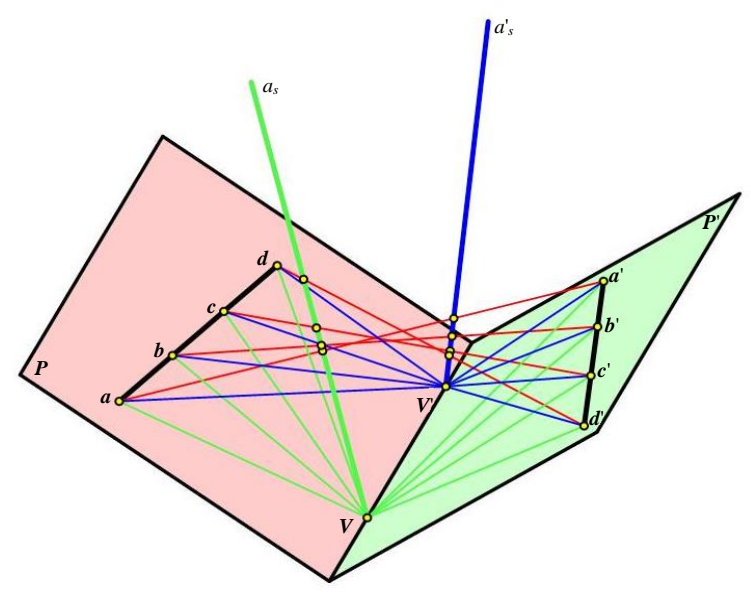

Fig. 46: Rigid second-order surfaces passing through a and a' and projecting any right abcd to the right correspondent a'b'c'd'

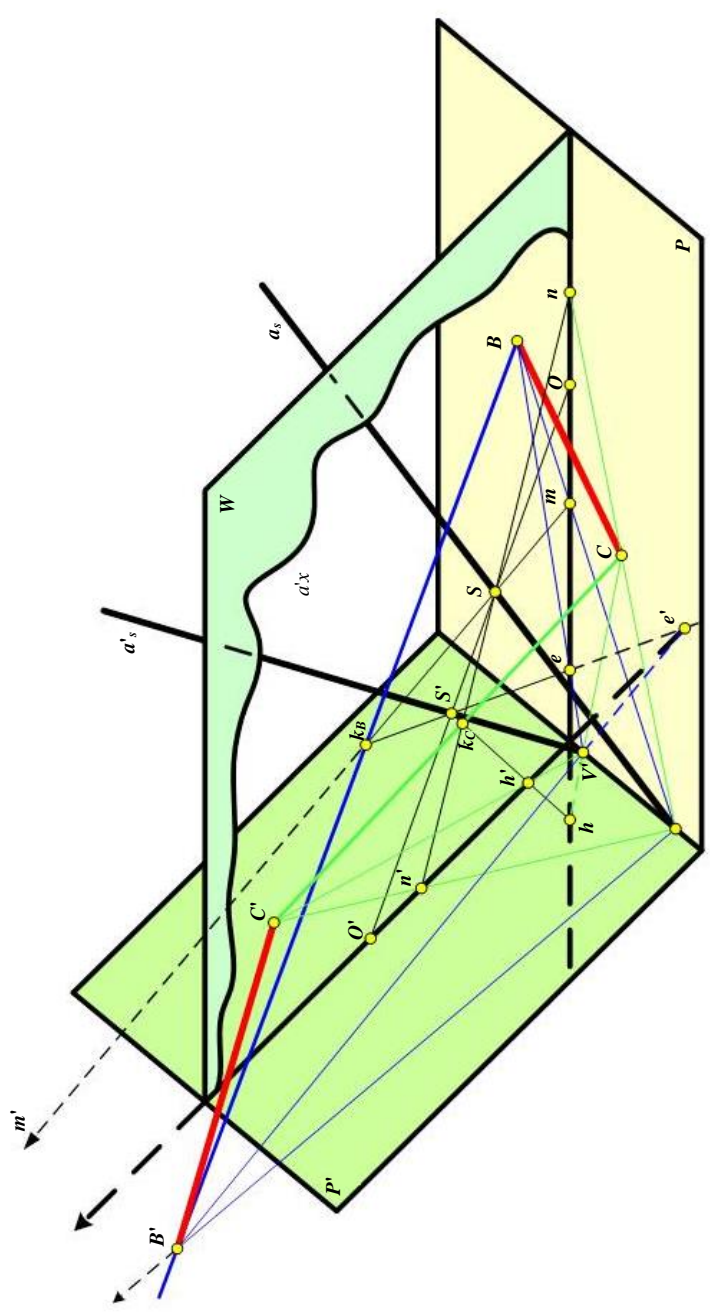

Fig. 47: Designing the points and straight lines from plan $P$ in correspondences belonging to plane $\mathrm{P}^{\mathrm{\prime}}$
The traces $\mathrm{Va}$ and $\mathrm{Va} / . . . \mathrm{V} / \mathrm{d}$ and $\mathrm{V} / \mathrm{d} /$ of the planes of the beams are correspondingly straight between them, forming stair beams with $\mathrm{V}$ and V/centers. In each of these centers two $\mathrm{Vabcd}$ and $\mathrm{Va} / \mathrm{b} / \mathrm{c} / \mathrm{d} /, \mathrm{V} / \mathrm{abcd}$ and $\mathrm{V} / \mathrm{a} / \mathrm{b} / \mathrm{c} / \mathrm{d} / \mathrm{ray}$ beams are obtained. A pair of beams with different centers are in perspective perspective and construct straight lines in the first and second planes. These lines are projective correspondents, because a pair of planes, taken from both bundles and passed through the corresponding points at intersection, give the rays (aa/, bb/, cc/, dd/) that pass through the as-/s and forms a second order ruled surface. The succession of the design of points and straight lines from one plane to another is the following.

Two planar correspondence planes $\mathrm{P}$ and $\mathrm{P}$ (Fig. 47) are mutually arranged such that firstly they intersect after two corresponding lines, in this case two pairs of corresponding points $\mathrm{V}$ and V/overlap.

Secondly, through these points are drawn two intersecting planes so that their traces in the corresponding projective planes coincide with their corresponding corners. Then at the intersection of these planes, which are designing, we will get the bilinear beam directories as and a/s.

Perpendicular to the planes $\mathrm{P}$ and $\mathrm{P} / \mathrm{draw}$ the $\mathrm{W}$ plane, find the intersection points $\mathrm{S}$ and $\mathrm{S} / \mathrm{of}$ the beam directories with this plane and draw through them the radius $\mathrm{OO} /$, which is in this plane.

The image of any point in plane $\mathrm{P}$ will be projected at the corresponding point in plane P/as follows.

Through the director $\mathrm{A}$ and $\mathrm{B}$ draw the VSB design plane and find the intersection with its VB track with the W plane in the plane P. From the point I received through the center $\mathrm{S}$ we plot the Sm of the VSB design plan in the W. Analog plane by the director of $\mathrm{a} / \mathrm{s}$ and point $\mathrm{B}$ plot the second design plane $\mathrm{V} / \mathrm{S} / \mathrm{B}$ and also find the intersection of its trace $\mathrm{V} / \mathrm{B}$ with the trace $\mathrm{W}$. The intersection of the tracks $\mathrm{mS}$ and $\mathrm{eS} / \mathrm{in}$ the $\mathrm{W}$ plane gives the point of intersection of the radius of design $\mathrm{BkB}$ with plan $\mathrm{W}$.

The similar $\mathrm{kC}$ point for the $\mathrm{CkC}$ radius will be obtained at the intersection of the $\mathrm{nS}$ and $\mathrm{hS} /$.

The projections of points $\mathrm{B}$ and $\mathrm{C}$ in plan $\mathrm{P} /(\mathrm{B} / \mathrm{and}$ $\mathrm{C} /$ ) are obtained at the intersection of the traces e/V/and $\mathrm{h} / \mathrm{V} /$ of the planes a/se/a/sh/in plan $\mathrm{P} / \mathrm{CKC}$. The traces of the planes asB/and asC/in the plane $\mathrm{P} /$, which pass to the as direc- tor, are obtained by means of the intersection points of the lines $\mathrm{nS}$ and $\mathrm{mS}$ with the trace $\mathrm{W}$ in the plane $\mathrm{P} /$. One of these points is denoted by the letter $\mathrm{n} /$, the other is outside the drawing at the intersection of the $\mathrm{mS}$ and $\mathrm{h} / \mathrm{O} /$.

If such a construction is made for a point orce belonging to the $\mathrm{BC}$ straight line, then depending on the accuracy of the construction, its projection will hit right $\mathrm{B} / \mathrm{C} /$.

\section{Conclusion}

The self-construction of the planar beam connected to each other in a bilinear bundle can be obtained in 
the case where the entire set of lines in the projection plane $\mathrm{P}$ (Fig. 46 and 47 ) are projected on plane P/. As a result, a set of ruled surfaces of the second order, which pass through the two bundle directories and its axis VV/. The latter, like the first two, is tangent to the entire set of rough surfaces of the bilinear bundle. Therefore, if there are to be drawn other planes with the exception of the planes $\mathrm{P}$ and $\mathrm{P} /$, then they will be tangent to the whole set of rusted surfaces of the second order and hence they will cut it only after straight lines of the same series as the projection planes $\mathrm{P}$ and $\mathrm{P} /$. Right $\mathrm{VV} /$ but belongs to another series of formation of the bundle of rusted surfaces of the second order, to the series of rays and intersects with all the surfaces. Thus, regardless of the fact that we will section the bilinear bundle with the beam of rays passing through its axis or not, this beam appears in the bundle alone, by the formation of coplanar sets, projectively connected to each other by straight lines of the same series that form rusted surfaces the second order, passing through the axis as. All these lines can also be considered as intersections of the planar plane formed by the VV/axis, with two planar beams with the axes $\alpha$ and $\alpha / \mathrm{s}$.

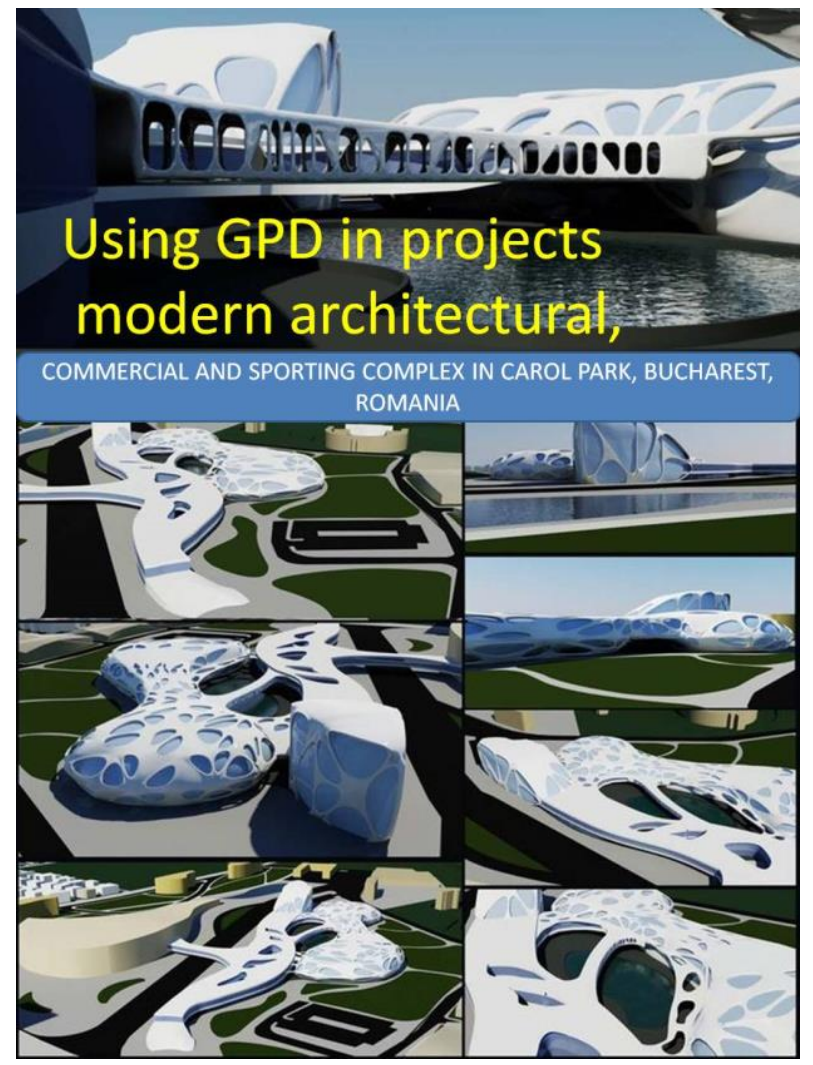

(a)

\section{Applications}

The self-cProjective and Descriptive Geometry has multiple applications in all areas of our everyday life. In Fig. 48a is presented the project of a commercial sports complex for Carol Park in Buchsarest, Romania, realized with the help of projective geometry and in $48 \mathrm{~b}$ a Science and Astronomy museum.

Using GPS and GPD for very precise locations and newer for measurement (determination) of the exact area of an area (mapping), is today a normal action. This combined instrument is nowadays indispensable in aviation, satellite broadcasting, GPS locations for any type of moving vehicle, military and civilian applications that require a perfect location in real time.

The use of the projective geometric knowledge, descriptive in the design of modern circular particle accelerators, of toroidal form, can be seen in Fig. 49.

Determination of flat sections in different geometric bodies, by means of descriptive geometry, by obtaining the peaks, or by the sides (Fig. 50a and 50b).

Sequence of a straight pyramid with an end plane can be followed in the Fig. 51.

In Fig. 52-57, the intersection of polyhedra can be traced.

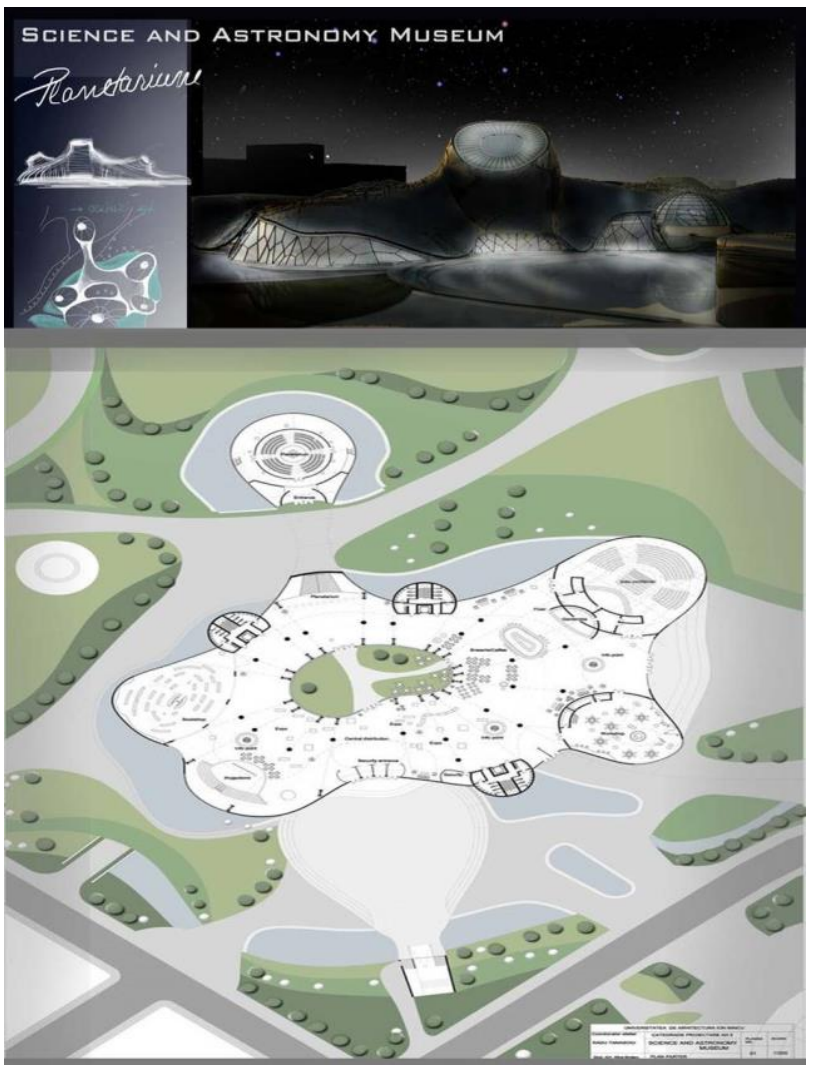

(b)

Fig. 48: Using GPS and GPD for very precise locations 
The use of the projective geometric knowledge,

descriptive in the design of modern circular particle accelerators, of toroidal form

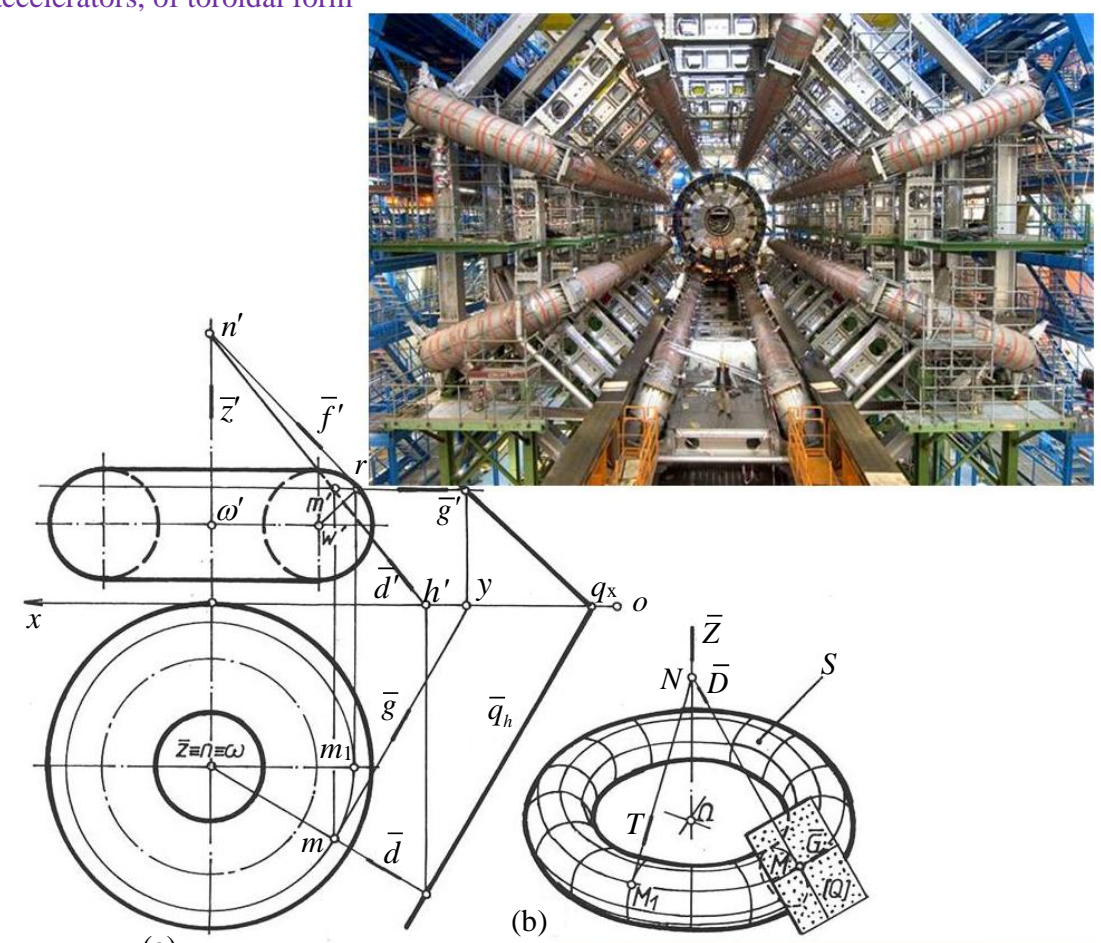

(a)
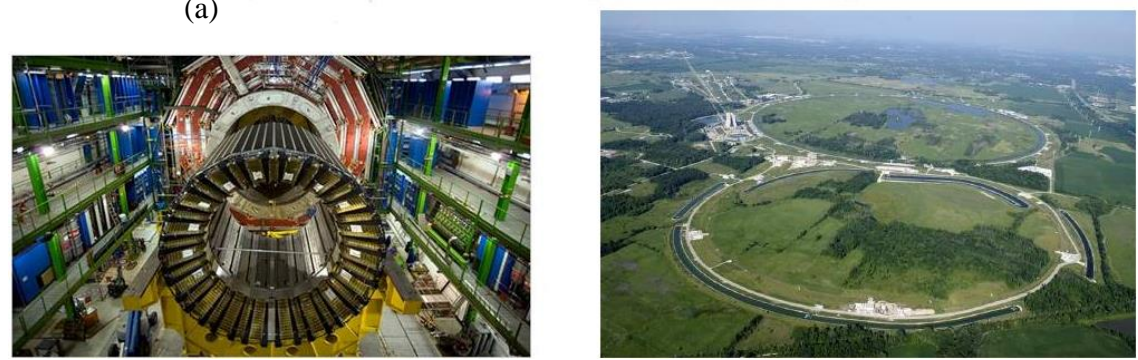

Fig. 49: The use of the projective geometric knowledge, descriptive in the design of modern circular particle accelerators, of toroidal form

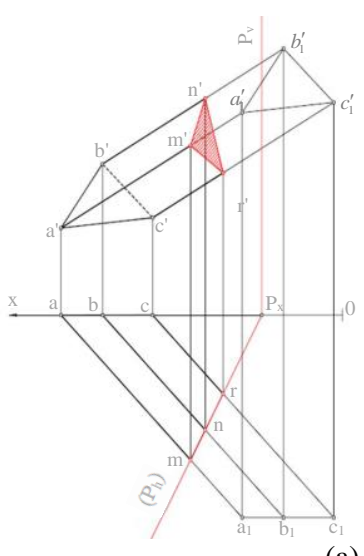

(a)

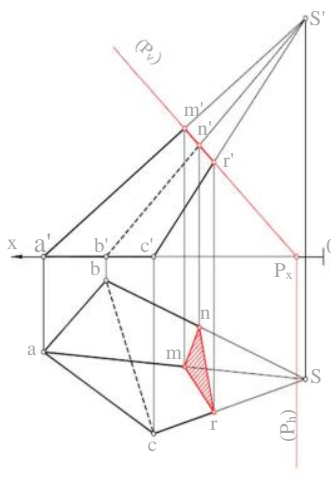

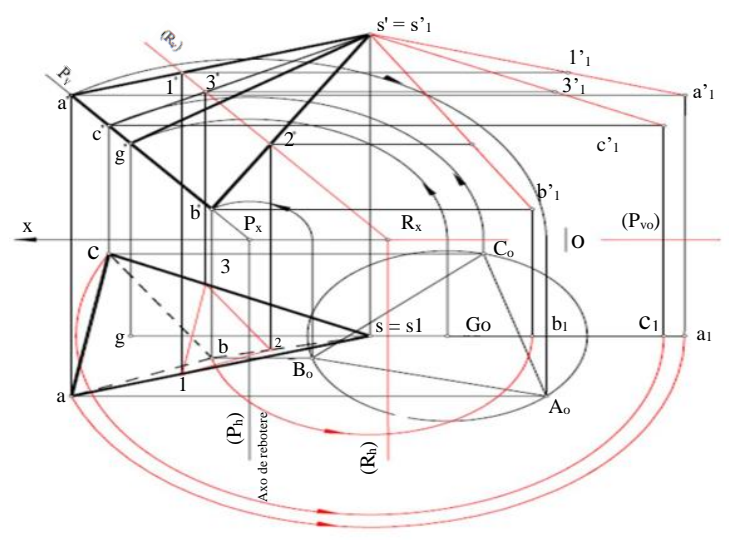

(b)

Fig. 50: Determination of flat sections in different geometric bodies, by means of descriptive geometry, by obtaining the peaks, or by the sides 


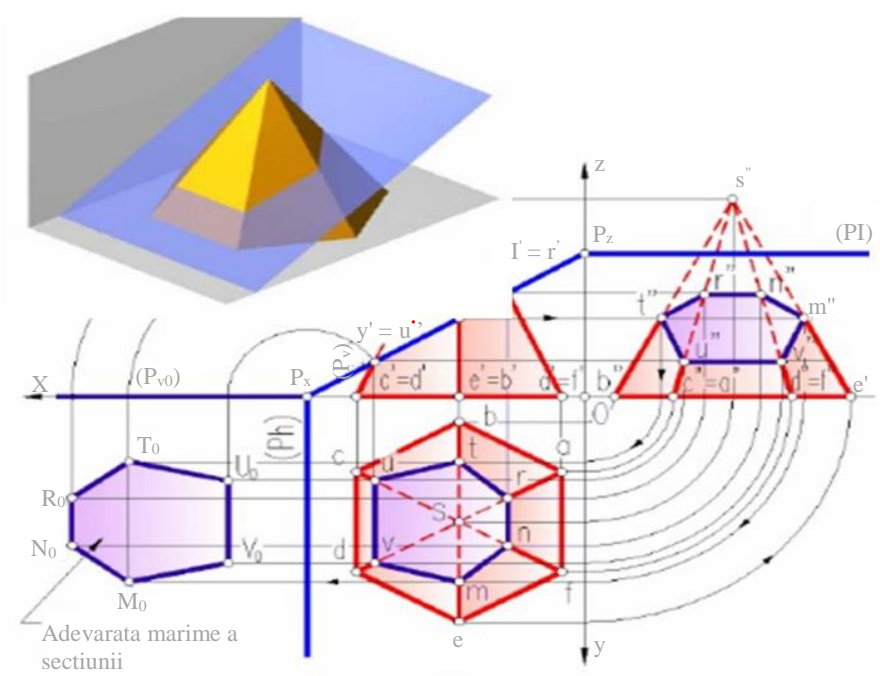

Fig. 51: Sequence of a straight pyramid with an end plane

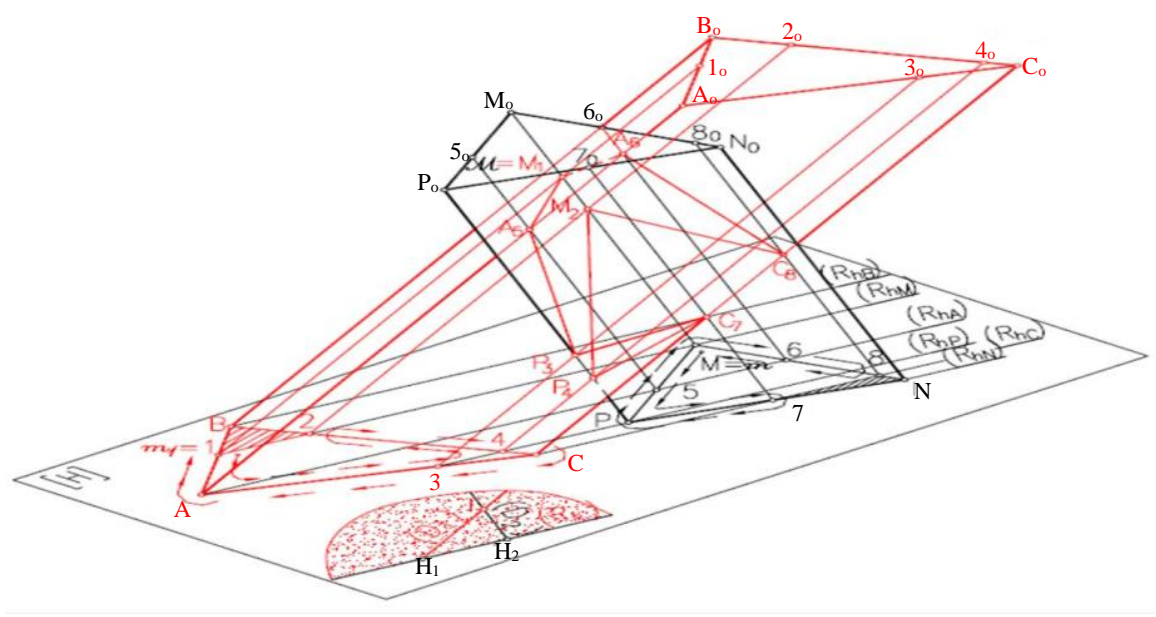

Fig. 52: The intersection of polyhedra; Prisma

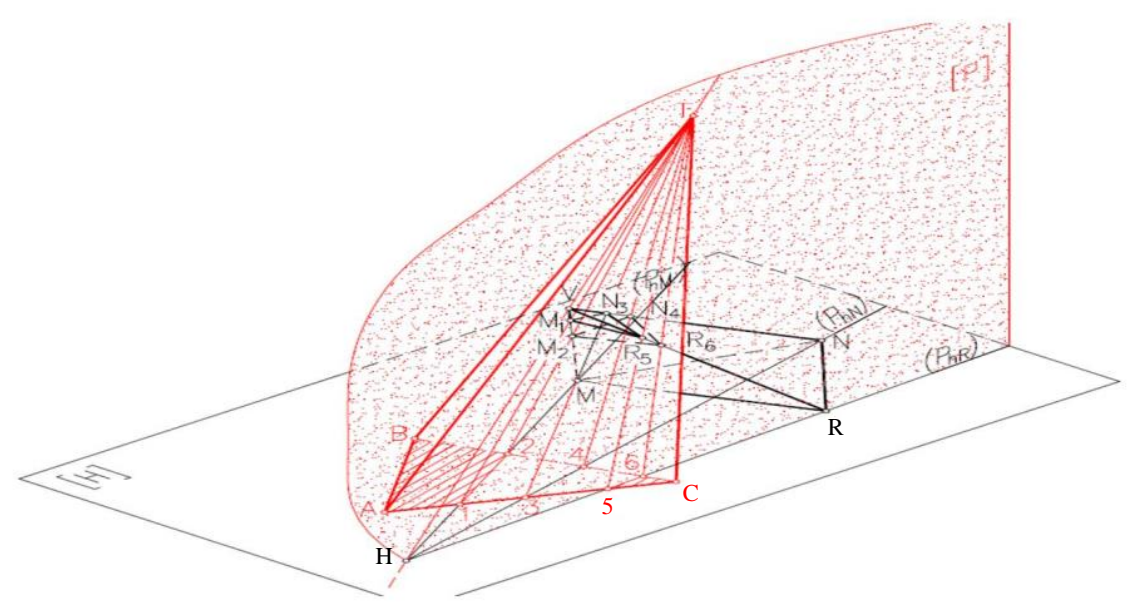

Fig. 53: The intersection of polyhedral 


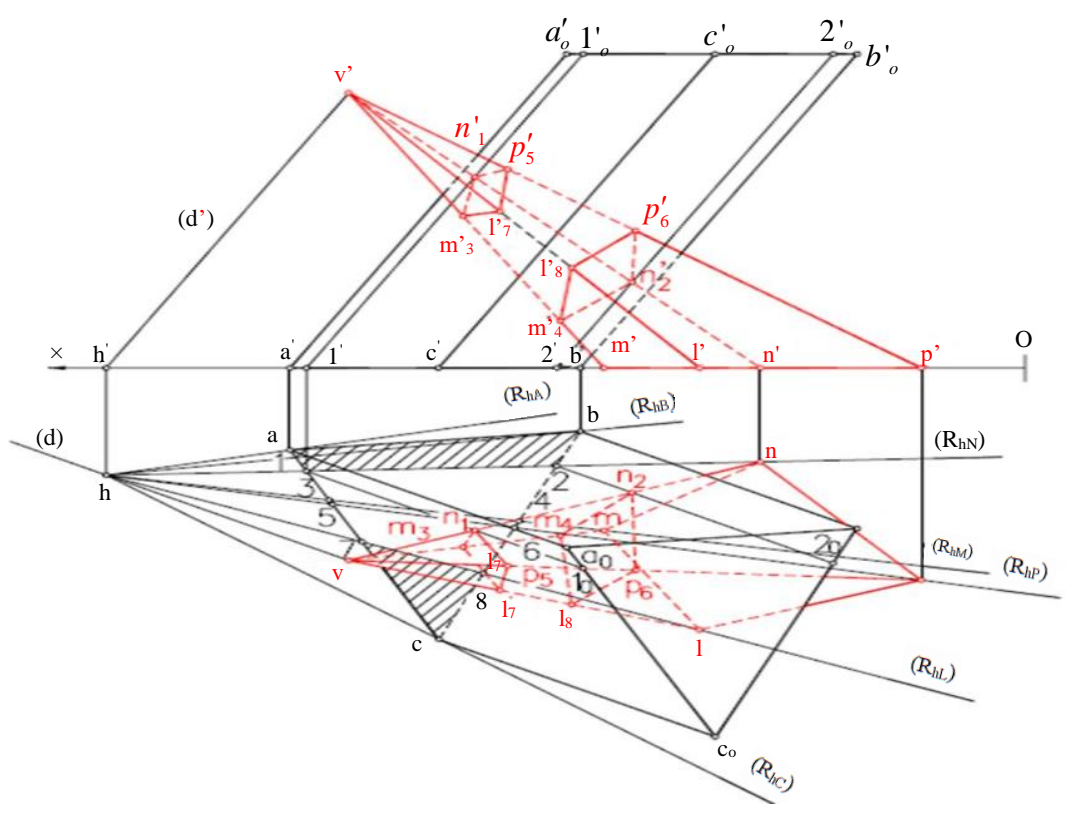

Fig. 54: The intersection of polyhedra; cone-cylinder

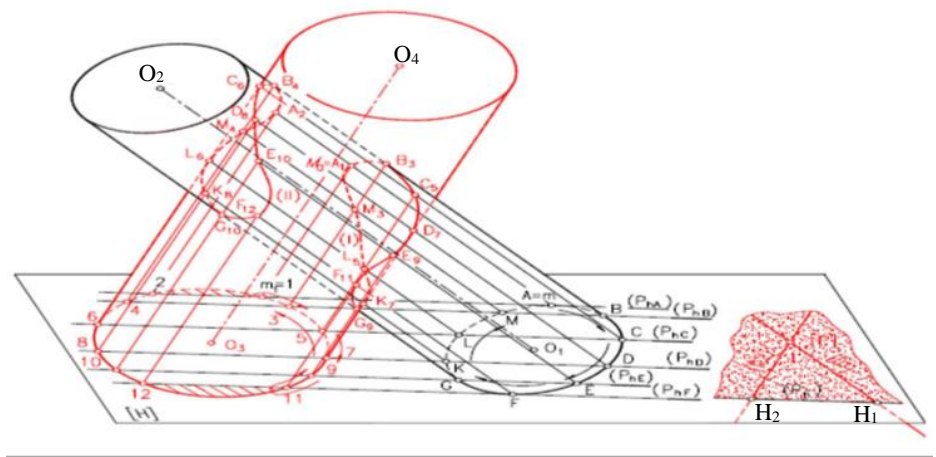

Fig. 55: The intersection of polyhedra; Cylinder

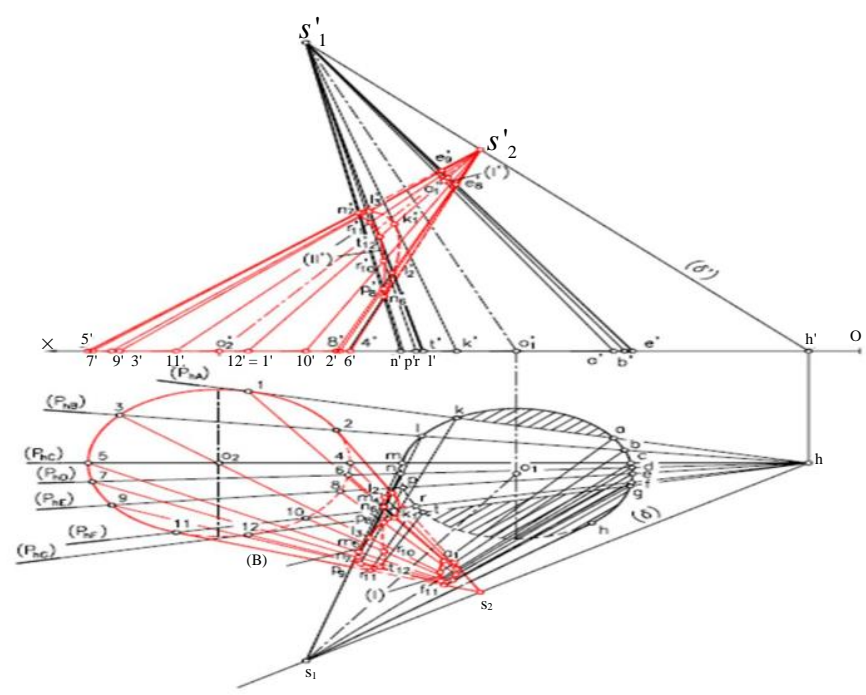

Fig. 56: The intersection of polyhedra; Cone 


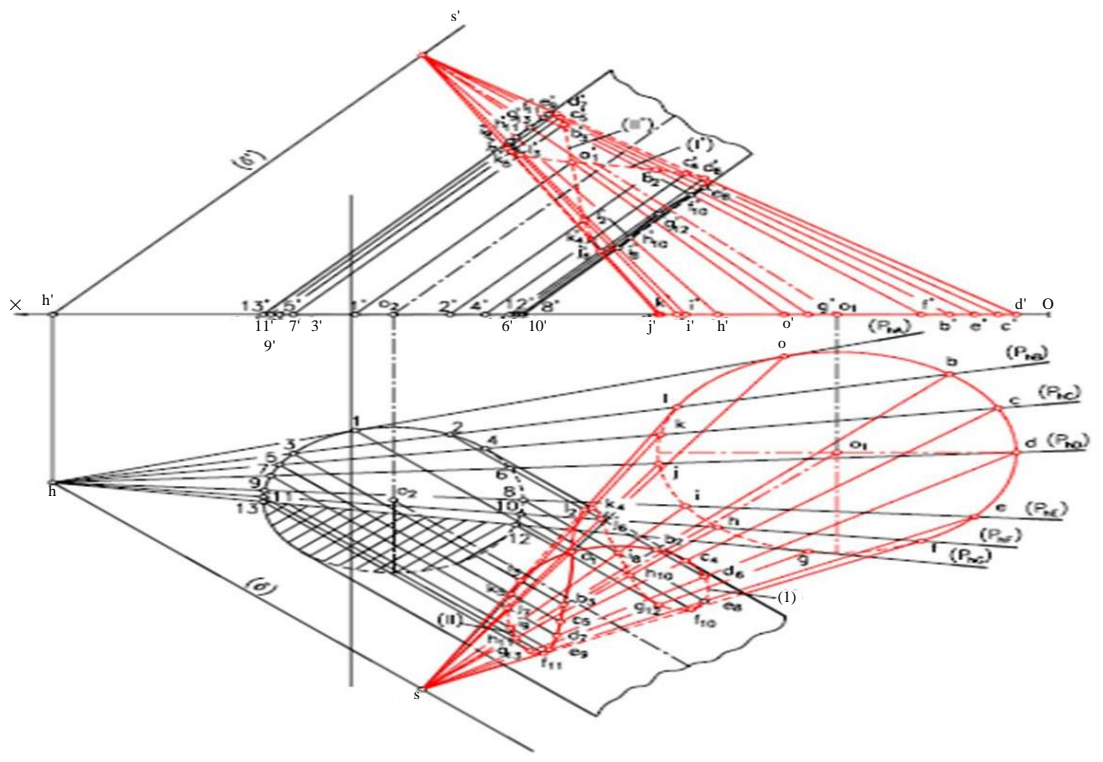

Fig. 57: The intersection of polyhedra; cone-cylinder

\section{Acknowledgement}

This text was acknowledged and appreciated by Dr. Veturia CHIROIU Honorific member of Technical Sciences Academy of Romania (ASTR) PhD supervisor in Mechanical Engineering.

\section{Funding Information}

Research contract:

1. Research contract: Contract number 36-5-4D/1986 from 24IV1985, beneficiary CNST RO (Romanian National Center for Science and Technology) Improving dynamic mechanisms.

2. Contract research integration. 19-91-3 from 29.03.1991; Beneficiary: MIS; TOPIC: Research on designing mechanisms with bars, cams and gears, with application in industrial robots.

3. Contract research. GR 69/10.05.2007: NURC in 2762; theme 8: Dynamic analysis of mechanisms and manipulators with bars and gears.

4. Labor contract, no. 35/22.01.2013, the UPB, "Stand for reading performance parameters of kinematics and dynamic mechanisms, using inductive and incremental encoders, to a Mitsubishi Mechatronic System" "PN-II-IN-CI-2012-1-0389".

All these matters are copyrighted! Copyrights: 394qodGnhhtej, from 17-02-2010 13:42:18; 463vpstuCGsiy, from 20-03-2010 12:45:30; 631sqfsgqvutm, from 24-05-2010 16:15:22; 933CrDztEfqow, from 07-01-2011 13:37:52.

\section{Ethics}

This article is original and contains unpublished material. Authors declare that are not ethical issues and no conflict of interest that may arise after the publication of this manuscript.

\section{References}

Ab-Rahman, M.S., H. Guna, MH. Harun, SD. Zan and K. Jumari, 2009. Cost-effective fabrication of self-made $1 \times 12$ polymer optical fiber-based optical splitters for automotive application. Am. J. Eng. Applied Sci., 2: 252-259. DOI: 10.3844/ajeassp.2009.252.259

Abam, F.I., I.U. Ugot and D.I. Igbong, 2012. Performance analysis and components irreversibilities of a (25 MW) gas turbine power plant modeled with a spray cooler. Am. J. Eng. Applied Sci., 5: 35-41.

DOI: 10.3844/ajeassp.2012.35.41

Abdelkrim, H., S.B. Othman, A.K.B. Salem and S.B. Saoud, 2012. Dynamic partial reconfiguration contribution on system on programmable chip architecture for motor drive implementation. Am. J. Eng. Applied Sci., 5: 15-24.

DOI: 10.3844/ajeassp.2012.15.24

Abdullah, M.Z., A. Saat and Z. Hamzah, 2011. Optimization of energy dispersive $\mathrm{x}$-ray fluorescence spectrometer to analyze heavy metals in moss samples. Am. J. Eng. Applied Sci., 4: 355-362. DOI: 10.3844/ajeassp.2011.355.362

Abdullah, M., A. F.M. Zain, Y. H. Ho and S. Abdullah, 2009. TEC and scintillation study of equatorial ionosphere: A month campaign over sipitang and parit raja stations, Malaysia. Am. J. Eng. Applied Sci., 2: 44-49. DOI: 10.3844/ajeassp.2009.44.49 
Abdullah, H. and S.A. Halim, 2009. Electrical and magnetoresistive studies $\mathrm{Nd}$ doped on La-Ba-Mn- $\mathrm{O}_{3}$ manganites for low-field sensor application. Am. J. Eng. Applied Sci., 2: 297-303.

DOI: 10.3844/ajeassp.2009.297.303

Abouobaida, H., 2016. Robust and efficient controller to design a standalone source supplied DC and AC load powered by photovoltaic generator. Am. J. Eng. Applied Sci., 9: 894-901.

DOI: 10.3844/ajeassp.2016.894.901

Abu-Ein, S., 2009. Numerical and analytical study of exhaust gases flow in porous media with applications to diesel particulate filters. Am. J. Eng. Applied Sci., 2: 70-75. DOI: 10.3844/ajeassp.2009.70.75

Abu-Lebdeh, M., G. Pérez-de León, S.A. Hamoush, R.D. Seals and V.E. Lamberti, 2016. Gas atomization of molten metal: Part II. Applications. Am. J. Eng. Applied Sci., 9: 334-349.

DOI: 10.3844/ajeassp.2016.334.349

Agarwala, S., 2016. A perspective on 3D bioprinting technology: Present and future. Am. J. Eng. Applied Sci., 9: 985-990. DOI: 10.3844/ajeassp.2016.985.990

Ahmed, M., R. Khan, M. Billah and S. Farhana, 2010. A novel navigation algorithm for hexagonal hexapod robot. Am. J. Eng. Applied Sci., 3: 320-327.

DOI: 10.3844/ajeassp.2010.320.327

Ahmed, M.K., H. Haque and H. Rahman, 2016. An approach to develop a dynamic job shop scheduling by fuzzy rule-based system and comparative study with the traditional priority rules. Am. J. Eng. Applied Sci., 9: 202-212.

DOI: 10.3844/ajeassp.2016.202.212

Akhesmeh, S., N. Pourmahmoud and H. Sedgi, 2008. Numerical study of the temperature separation in the ranque-hilsch vortex tube. Am. J. Eng. Applied Sci., 1: 181-187. DOI: 10.3844/ajeassp.2008.181.187

Akubue, A., 2011. Appropriate technology for socioeconomic development in third world countries. J. Technol. Stud., 26: 33-43.

DOI: 10.21061/jots.v26i1.a.6

Al-Abbas, I.K., 2009. Reduced order models of a current source inverter induction motor drive. Am. J. Eng. Applied Sci., 2: 39-43.

DOI: 10.3844/ajeassp.2009.39.43

Al-Hasan, M.I. and A.S. Al-Ghamdi, 2016. Energy balance for a diesel engine operates on a pure biodiesel, diesel fuel and biodiesel-diesel blends. Am. J. Eng. Applied Sci., 9: 458-465.

DOI: 10.3844/ajeassp.2016.458.465

Al Smadi, T.A., 2011. Low cost smart sensor design. Am. J. Eng. Applied Sci., 4: 162-168. DOI: 10.3844/ajeassp.2011.162.168

Al Qadi, A.N.S., M.B.A. ALhasanat, A. AL Dahamsheh and S. AL Zaiydneen, 2016a. Using of box-benken method to predict the compressive strength of selfcompacting concrete containing Wadi Musa bentonite, Jordan. Am. J. Eng. Applied Sci., 9: 406-411. DOI: 10.3844/ajeassp.2016.406.411
Al Qadi, A.N.S., M.B.A. Alhasanat and M. Haddad, 2016b. Effect of crumb rubber as coarse and fine aggregates on the properties of asphalt concrete. Am. J. Eng. Applied Sci., 9: 558-564.

DOI: 10.3844/ajeassp.2016.558.564

Aleksic, S. and A. Lovric, 2011. Energy consumption and environmental implications of wired access networks. Am. J. Eng. Applied Sci., 4: 531-539. DOI: 10.3844/ajeassp.2011.531.539

Alhasanat, M.B., A.N. Al Qadi, O.A. Al Khashman and A. Dahamsheh, 2016. Scanning electron microscopic evaluation of self-compacting concrete spalling at elevated temperatures. Am. J. Eng. Applied Sci., 9: 119-127. DOI: 10.3844/ajeassp.2016.119.127

Ali, K.S. and JL. Shumaker, 2013. Hardware in the loop simulator for multi-agent unmanned aerial vehicles environment. Am. J. Eng. Applied Sci., 6: 172-177. DOI: 10.3844/ajeassp.2013.172.177

Ali, G.A.M., O. Fouad and S.A. Makhlouf, 2016. Electrical properties of cobalt oxide/silica nanocomposites obtained by sol-gel technique. Am. J. Eng. Applied Sci., 9: 12-16. DOI: 10.3844/ajeassp.2016.12.16

Al-Nasra, M. Daoudb and T.M. Abu-Lebdeh, 2015. The use of the super absorbent polymer as water blocker in concrete structures. Am. J. Eng. Applied Sci., 8: 659-665. DOI: 10.3844/ajeassp.2015.659.665

Alwetaishi, M.S., 2016. Impact of building function on thermal comfort: A review paper. Am. J. Eng. Applied Sci., 9: 928-945.

DOI: 10.3844/ajeassp.2016.928.945

Aly, W.M. and M.S. Abuelnasr, 2010. Electronic design automation using object oriented electronics. Am. J. Eng. Applied Sci., 3: 121-127.

DOI: 10.3844/ajeassp.2010.121.127

Amani, N., 2016. Design and implementation of optimum management system using cost evaluation and financial analysis for prevention of building failure. Am. J. Eng. Applied Sci., 9: 281-296. DOI: 10.3844/ajeassp.2016.281.296

Amer, S., S. Hamoush and T.M. Abu-Lebdeh, 2015. Experimental evaluation of the raking energy in damping system of steel stud partition walls. Am. J. Eng. Applied Sci., 8: 666-677.

DOI: 10.3844/ajeassp.2015.666.677

Anizan, S., K. Yusri, C.S. Leong, N. Amin and S. Zaidi et al., 2011. Effects of the contact resistivity variations of the screen-printed silicon solar cell. Am. J. Eng. Applied Sci., 4: 328-331.

DOI: 10.3844/ajeassp.2011.328.331

Angeles, J. and C. Lopez-Cajun, 1988. Optimal synthesis of cam mechanisms with oscillating flat-face followers. Mechanism Mach. Theory, 23: 1-6. DOI: $10.1016 / 0094-114 X(88) 90002-X$

Antonescu, P., 2000. Mechanisms and Handlers. 1st Edn., Printech Publishing House, Bucharest. 
Antonescu, P. and FIT. Petrescu, 1985. An analytical method of synthesis of cam mechanism and flat stick. Proceedings of the 4th International Symposium on Theory and Practice of Mechanisms, (TPM' 85), Bucharest.

Antonescu, P. and F.I.T. Petrescu, 1989. Contributions to cinetoelastodynamic analysis of distribution mechanisms. Bucharest.

Antonescu, P., M. Oprean and F.I.T. Petrescu, 1985a. Contributions to the synthesis of oscillating cam mechanism and oscillating flat stick. Proceedings of the 4th International Symposium on Theory and Practice of Mechanisms, (TPM' 85), Bucharest.

Antonescu, P., M. Oprean and F.I.T. Petrescu, 1985b. At the projection of the oscillate cams, there are mechanisms and distribution variables. Proceedings of the 5th Conference of Engines, Automobiles, Tractors and Agricultural Machines, (AMA' 58), IMotors and Cars, Brasov.

Antonescu, P., M. Oprean and F.I.T. Petrescu, 1986. Projection of the profile of the rotating camshaft acting on the oscillating plate with disengagement. Proceedings of the 3rd National Computer-aided Design Symposium in the field of Mechanisms and Machine Parts, (MMP' 86), Brasov.

Antonescu, P., M. Oprean and F.I.T. Petrescu, 1987. Dynamic analysis of the cam distribution mechanisms. Proceedings of the 7th National Symposium on Industrial Robots and Space Mechanisms, (RSM' 87), Bucharest.

Antonescu, P., M. Oprean and F.I.T. Petrescu, 1988. Analytical synthesis of Kurz profile, rotating the flat cam. Mach, Build. Rev.

Antonescu, P., F.I.T. Petrescu and O. Antonescu, 1994. Contributions to the synthesis of the rotating cam mechanism and the tip of the balancing tip. Brasov.

Antonescu, P., F.I.T. Petrescu and D. Antonescu, 1997. Geometrical synthesis of the rotary cam and balance tappet mechanism. Bucharest, 3: 23-23.

Antonescu, P., F.I.T. Petrescu and O. Antonescu, 2000a. Contributions to the synthesis of the rotary disc-cam profile. Proceedings of the 8th International Conference on the Theory of Machines and Mechanisms, (TMM' 00), Liberec, Czech Republic, pp: 51-56.

Antonescu, P., F.I.T. Petrescu and O. Antonescu, 2000b. Synthesis of the rotary cam profile with balance follower. Proceedings of the 8th Symposium on Mechanisms and Mechanical Transmissions, (MMT' 00), Timişoara, pp: 39-44.

Antonescu, P., F. Petrescu and O. Antonescu, 2001. Contributions to the synthesis of mechanisms with rotary disc-cam. Proceedings of the 8th IFToMM International Symposium on Theory of Machines and Mechanisms, (TMM' 01), Bucharest, ROMANIA, pp: 31-36.
Ascione, F., N. Bianco, R.F. De Masi, F. de Rossi and C. De Stasio et al., 2016. Energy audit of health care facilities: dynamic simulation of energy performances and energy-oriented refurbishment of system and equipment for microclimatic control. Am. J. Eng. Applied Sci., 9: 814-834.

DOI: 10.3844/ajeassp.2016.814.834

Augustine, A., R.D. Prakash, R. Xavier and M.C. Parassery, 2016. Review of signal processing techniques for detection of power quality events. Am. J. Eng. Applied Sci., 9: 364-370.

DOI: 10.3844/ajeassp.2016.364.370

Aversa, R., R.V.V. Petrescu, A. Apicella and F.I.T. Petrescu, 2017a. Nano-diamond hybrid materials for structural biomedical application. Am. J. Biochem. Biotechnol., 13: 34-41. DOI: 10.3844/ajbbsp.2017.34.41

Aversa, R., R.V. Petrescu, B. Akash, R.B. Bucinell and J.M. Corchado et al., 2017b. Kinematics and forces to a new model forging manipulator. Am. J. Applied Sci., 14: 60-80. DOI: 10.3844/ajassp.2017.60.80

Aversa, R., R.V. Petrescu, A. Apicella, F.I.T. Petrescu and J.K. Calautit et al., 2017c. Something about the $\mathrm{V}$ engines design. Am. J. Applied Sci., 14: 34-52. DOI: 10.3844/ajassp.2017.34.52

Aversa, R., D. Parcesepe, R.V.V. Petrescu, F. Berto and G. Chen et al., 2017d. Process ability of bulk metallic glasses. Am. J. Applied Sci., 14: 294-301. DOI: 10.3844/ajassp.2017.294.301

Aversa, R., R.V.V. Petrescu, B. Akash, R.B. Bucinell and J.M. Corchado et al., 2017e. Something about the balancing of thermal motors. Am. J. Eng. Applied Sci., 10: 200.217. DOI: 10.3844/ajeassp.2017.200.217

Aversa, R., F.I.T. Petrescu, R.V. Petrescu and A. Apicella, 2016a. Biomimetic FEA bone modeling for customized hybrid biological prostheses development. Am. J. Applied Sci., 13: 1060-1067. DOI: 10.3844/ajassp.2016.1060.1067

Aversa, R., D. Parcesepe, R.V. Petrescu, G. Chen and F.I.T. Petrescu et al., 2016b. Glassy amorphous metal injection molded induced morphological defects. Am. J. Applied Sci., 13: 1476-1482. DOI: 10.3844 /ajassp.2016.1476.1482

Aversa, R., R.V. Petrescu, F.I.T. Petrescu and A. Apicella, 2016c. Smart-factory: Optimization and process control of composite centrifuged pipes. Am. J. Applied Sci., 13: 1330-1341. DOI: 10.3844/ajassp.2016.1330.1341

Aversa, R., F. Tamburrino, R.V. Petrescu, F.I.T. Petrescu and M. Artur et al., 2016d. Biomechanically inspired shape memory effect machines driven by muscle like acting NiTi alloys. Am. J. Applied Sci., 13: 1264-1271. DOI: 10.3844/ajassp.2016.1264.1271

Aversa, R., E.M. Buzea, R.V. Petrescu, A. Apicella and M. Neacsa et al., 2016e. Present a mechatronic system having able to determine the concentration 
of carotenoids. Am. J. Eng. Applied Sci., 9: 11061111. DOI: 10.3844/ajeassp.2016.1106.1111

Aversa, R., R.V. Petrescu, R. Sorrentino, F.I.T. Petrescu and A. Apicella, 2016f. Hybrid ceramo-polymeric nanocomposite for biomimetic scaffolds design and preparation. Am. J. Eng. Applied Sci., 9: 1096-1105. DOI: 10.3844/ajeassp.2016.1096.1105

Aversa, R., V. Perrotta, R.V. Petrescu, C. Misiano and F.I.T. Petrescu et al., 2016g. From structural colors to super-hydrophobicity and achromatic transparent protective coatings: Ion plating plasma assisted $\mathrm{TiO}_{2}$ and $\mathrm{SiO}_{2}$ nano-film deposition. Am. J. Eng. Applied Sci., 9: 1037-1045.

DOI: 10.3844/ajeassp.2016.1037.1045

Aversa, R., R.V. Petrescu, F.I.T. Petrescu and A. Apicella, 2016h. Biomimetic and evolutionary design driven innovation in sustainable products development. Am. J. Eng. Applied Sci., 9: 1027-1036. DOI: 10.3844/ajeassp.2016.1027.1036

Aversa, R., R.V. Petrescu, A. Apicella and F.I.T. Petrescu, 2016i. Mitochondria are naturally micro robots - a review. Am. J. Eng. Applied Sci., 9: 991-1002.

DOI: 10.3844/ajeassp.2016.991.1002

Aversa, R., R.V. Petrescu, A. Apicella and F.I.T. Petrescu, 2016j. We are addicted to vitamins $\mathrm{C}$ and E-A review. Am. J. Eng. Applied Sci., 9: 10031018. DOI: 10.3844/ajeassp.2016.1003.1018

Aversa, R., R.V. Petrescu, A. Apicella and F.I.T. Petrescu, 2016k. Physiologic human fluids and swelling behavior of hydrophilic biocompatible hybrid ceramo-polymeric materials. Am. J. Eng. Applied Sci., 9: 962-972.

DOI: 10.3844/ajeassp.2016.962.972

Aversa, R., R.V. Petrescu, A. Apicella and F.I.T. Petrescu, 20161. One can slow down the aging through antioxidants. Am. J. Eng. Applied Sci., 9: 1112-1126. DOI: 10.3844/ajeassp.2016.1112.1126

Aversa, R., R.V. Petrescu, A. Apicella and F.I.T. Petrescu, 2016m. About homeopathy or «Similia Similibus Curentur 》. Am. J. Eng. Applied Sci., 9: 1164-1172. DOI: 10.3844/ajeassp.2016.1164.1172

Aversa, R., R.V. Petrescu, A. Apicella and F.I.T. Petrescu, 2016n. The basic elements of life's. Am. J. Eng. Applied Sci., 9: 1189-1197.

DOI: 10.3844/ajeassp.2016.1189.1197

Aversa, R., F.I.T. Petrescu, R.V. Petrescu and A. Apicella, 2016o. Flexible stem trabecular prostheses. Am. J. Eng. Applied Sci., 9: 1213-1221. DOI: 10.3844/ajeassp.2016.1213.122

Babayemi, A.K., 2016. Thermodynamics, non-linear isotherms, statistical modeling and optimization of phosphorus adsorption from wastewater. Am. J. Eng. Applied Sci., 9: 1019-1026.

DOI: 10.3844/ajeassp.2016.1019.1026
Bakar, R.A., M.K. Mohammed and M.M. Rahman, 2009. Numerical study on the performance characteristics of hydrogen fueled port injection internal combustion engine. Am. J. Eng. Applied Sci., 2: 407-415.

DOI: 10.3844/ajeassp.2009.407.415

Barone, G., A. Buonomano, C. Forzano and A. Palombo, 2016. WLHP systems in commercial buildings: A case study analysis based on a dynamic simulation approach. Am. J. Eng. Applied Sci., 9: 659-668. DOI: 10.3844/ajeassp.2016.659.668

Bedon, C., 2016. Review on the use of FRP composites for facades and building skins. Am. J. Eng. Applied Sci., 9: 713-723. DOI: $10.3844 /$ ajeassp.2016.713.723

Bedon, C. and C. Amadio, 2016. A unified approach for the shear buckling design of structural glass walls with non-ideal restraints. Am. J. Eng. Applied Sci., 9: 64-78. DOI: 10.3844/ajeassp.2016.64.78

Bedon, C. and C. Louter, 2016. Finite-element numerical simulation of the bending performance of posttensioned structural glass beams with adhesively bonded CFRP tendons. Am. J. Eng. Applied Sci., 9: 680-691. DOI: 10.3844/ajeassp.2016.680.691

Bier, H. and S. Mostafavi, 2015. Structural optimization for materially informed design to robotic production processes. Am. J. Eng. Applied Sci., 8: 549-555. DOI: 10.3844/ajeassp.2015.549.555

Bolonkin, A., 2009a. Femtotechnology: Nuclear matter with fantastic properties. Am. J. Eng. Applied Sci., 2: 501-514. DOI: 10.3844/ajeassp.2009.501.514

Bolonkin, A., 2009b. Converting of matter to nuclear energy by ab-generator. Am. J. Eng. Applied Sci., 2: 683-693. DOI: 10.3844/ajeassp.2009.683.693

Boucetta, A., 2008. Vector control of a variable reluctance machine stator and rotor discs imbricates. Am. J. Eng. Applied Sci., 1: 260-265. DOI: 10.3844/ajeassp.2008.260.265

Bourahla, N. and A. Blakeborough, 2015. Similitude distortion compensation for a small scale model of a knee braced steel frame. Am. J. Eng. Applied Sci., 8: 481-488. DOI: 10.3844/ajeassp.2015.481.488

Bucinell, R.B., 2016. Stochastic model for variable amplitude fatigue induced delamination growth in graphite/epoxy laminates. Am. J. Eng. Applied Sci., 9: 635-646. DOI: 10.3844/ajeassp.2016.635.646

Budak, S., Z. Xiao, B. Johnson, J. Cole and M. Drabo et al., 2016. Highly-efficient advanced thermoelectric devices from different multilayer thin films. Am. J. Eng. Applied Sci., 9: 356-363. DOI: 10.3844/ajeassp.2016.356.363

Buonomano, A., F. Calise and M. Vicidomini, 2016a. A novel prototype of a small-scale solar power plant: Dynamic simulation and thermoeconomic analysis. Am. J. Eng. Applied Sci., 9: 770-788. DOI: 10.3844 /ajeassp.2016.770.788 
Buonomano, A., F. Calise, M.D. d'Accadia, R. Vanoli and M. Vicidomini, 2016b. Simulation and experimental analysis of a demonstrative solar heating and cooling plant installed in Naples (Italy). Am. J. Eng. Applied Sci., 9: 798-813.

DOI: 10.3844/ajeassp.2016.798.813

Cao, W., H. Ding, Z. Bin and C. Ziming, 2013. New structural representation and digital-analysis platform for symmetrical parallel mechanisms. Int. J. Adv. Robotic Sys. DOI: 10.5772/56380

Calise, F., M.D. dâ' Accadia, L. Libertini, E. Quiriti and M. Vicidomini, 2016b. Dynamic simulation and optimum operation strategy of a trigeneration system serving a hospital. Am. J. Eng. Applied Sci., 9: 854-867. DOI: 10.3844/ajeassp.2016.854.867

Campo, T., M. Cotto, F. Marquez, E. Elizalde and C. Morant, 2016. Graphene synthesis by plasmaenhanced CVD growth with ethanol. Am. J. Eng. Applied Sci., 9: 574-583.

DOI: 10.3844/ajeassp.2016.574.583

Cardu, M., P. Oreste and T. Cicala, 2009. Analysis of the tunnel boring machine advancement on the Bologna-Florence railway link. Am. J. Eng. Applied Sci., 2: 416-420.

DOI: 10.3844/ajeassp.2009.416.420

Casadei, D., 2015. Bayesian statistical inference for number counting experiments. Am. J. Eng. Applied Sci., 8: 730-735

DOI: 10.3844/ajeassp.2015.730.735

Cataldo, R., 2006. Overview of planetary power system options for education. ITEA Human Exploration Project Authors, Glenn Research Center. Brooke Park, $\mathrm{OH}$

Chang, S.P., M.C. Chen and J.D. Lin, 2015. Study of heat-treated steel and related applications. Am. J. Eng. Applied Sci., 8: 611-619.

DOI: 10.3844/ajeassp.2015.611.619

Chen, G. and L. Xu, 2016. A general strategy to enhance up conversion luminescence in rare-earth-ion-doped oxide nanocrystals. Am. J. Eng. Applied Sci., 9: 7983. DOI: 10.3844/ajeassp.2016.79.83

Chiozzi, A., G. Milani, N. Grillanda and A. Tralli, 2016. An adaptive procedure for the limit analysis of FRP reinforced masonry vaults and applications. Am. J. Eng. Applied Sci., 9: 735-745.

DOI: 10.3844/ajeassp.2016.735.745

Chisari, C. and C. Bedon, 2016. Multi-objective optimization of FRP jackets for improving the seismic response of reinforced concrete frames. Am. J. Eng. Applied Sci., 9: 669-679. DOI: 10.3844/ajeassp.2016.669.679

Comanescu, A., 2010. Bazele Modelarii Mecanismelor. 1st Edn., E. Politeh, Press, Bucureşti, pp: 274.

Darabi, A., S.A. Soleamani and A. Hassannia, 2008. Fuzzy based digital automatic voltage regulator of a synchronous generator with unbalanced loads. Am. J. Eng. Applied Sci., 1: 280-286. DOI: 10.3844/ajeassp.2008.280.286
Daud, H., N. Yahya, A.A. Aziz and M.F. Jusoh, 2008. Development of wireless electric concept powering electrical appliances. Am. J. Eng. Applied Sci., 1: 12-15. DOI: 10.3844/ajeassp.2008.12.15

Demetriou, D., N. Nikitas and K.D. Tsavdaridis, 2015. Semi active tuned mass dampers of buildings: A simple control option. Am. J. Eng. Applied Sci., 8: 620-632. DOI: 10.3844/ajeassp.2015.620.632

Dixit, S. and S. Pal, 2015. Synthesis and characterization of ink (Carbon)-perovskite/polyaniline ternary composite electrode for sodium chloride separation. Am. J. Eng. Applied Sci., 8: 527-537.

DOI: 10.3844 ajeassp.2015.527.537

Djalel, D., M. Mourad and H. Labar, 2013. New approach of electromagnetic fields of the lightning discharge. Am. J. Eng. Applied Sci., 6: 369-383. DOI: 10.3844/ajeassp.2013.369.383

Dong, H., N. Giakoumidis, N. Figueroa and N. Mavridis, 2013. Approaching behaviour monitor and vibration indication in developing a General Moving Object Alarm System (GMOAS). Int. J. Adv. Robotic Sys. DOI: $10.5772 / 56586$

Ebrahim, N.A., S. Ahmed, S.H.A. Rashid and Z. Taha, 2012. Technology use in the virtual R\&D teams. Am. J. Eng. Applied Sci., 5: 9-14. DOI: 10.3844/ajeassp.2012.9.14

El-Labban, H.F., M. Abdelaziz and E.R.I. Mahmoud, 2013. Modification of carbon steel by laser surface melting: Part I: Effect of laser beam travelling speed on microstructural features and surface hardness. Am. J. Eng. Applied Sci., 6: 352-359. DOI: 10.3844/ajeassp.2013.352.359

Elliott, A., S. AlSalihi, A.L. Merriman and M.M. Basti, 2016. Infiltration of nanoparticles into porous binder jet printed parts. Am. J. Eng. Applied Sci., 9: 128133. DOI: 10.3844/ajeassp.2016.128.133

Elmeddahi, Y., H. Mahmoudi, A. Issaadi, M.F.A. Goosen and R. Ragab, 2016b. Evaluating the effects of climate change and variability on water resources: A case study of the cheliff Basin in Algeria. Am. J. Eng. Applied Sci., 9: 835-845. DOI: 10.3844 ajeassp.2016.835.845

El-Tous, Y., 2008. Pitch angle control of variable speed wind turbine. Am. J. Eng. Applied Sci., 1: 118-120. DOI: 10.3844/ajeassp.2008.118.120

Faizal, A., S. Mulyono, R. Yendra and A. Fudholi, 2016. Design Maximum Power Point Tracking (MPPT) on photovoltaic panels using fuzzy logic method. Am. J. Eng. Applied Sci., 9: 789-797. DOI: $10.3844 /$ ajeassp.2016.789.797

Farahani, A.S., N.M. Adam and M.K.A. Ariffin, 2010. Simulation of airflow and aerodynamic forces acting on a rotating turbine ventilator. Am. J. Eng. Applied Sci., 3: 159-170. DOI: 10.3844/ajeassp.2010.159.170 
Farokhi, E. and M. Gordini, 2015. Investigating the parameters influencing the behavior of knee braced steel structures. Am. J. Eng. Applied Sci., 8: 567574. DOI: 10.3844/ajeassp.2015.567.574

Fathallah, A.Z.M. and R.A. Bakar, 2009. Prediction studies for the performance of a single cylinder high speed spark ignition linier engine with spring mechanism as return cycle. Am. J. Eng. Applied Sci., 2: 713-720.

DOI: 10.3844/ajeassp.2009.713.720

Fawcett, G.F. and J.N. Fawcett, 1974. Comparison of Polydyne and Non Polydyne Cams. In: Cams and Cam Mechanisms, Rees Jones, J. (Ed.), MEP, London and Birmingham, Alabama.

Fen, Y.W., W.M.M. Yunus, M.M. Moksin, Z.A. Talib and N.A. Yusof, 2011. Optical properties of crosslinked chitosan thin film with glutaraldehyde using surface Plasmon resonance technique. Am. J. Eng. Applied Sci., 4: 61-65.

DOI: 10.3844 /ajeassp.2011.61.65

Feraga, C.E., A. Moussaoui, A. Bouldjedri and A. Yousfi, 2009. Robust position controller for a permanent magnet synchronous actuator. Am. J. Eng. Applied Sci., 2: 388-392.

DOI: 10.3844/ajeassp.2009.388.392

Franklin, D.J., 1930. Ingenious Mechanisms for Designers and Inventors. 1st Edn., Industrial Press Publisher.

Fu, Y.F., J. Gong, H. Huang, Y.J. Liu and D. Zhu et al., 2015. Parameters optimization of adaptive cashew shelling cutter based on BP neural network and genetic algorithm. Am. J. Eng. Applied Sci., 8: 648-658. DOI: 10.3844/ajeassp.2015.648.658

Gao, F., W.Z. Guo, Q.Y. Song and F.S. Du, 2010. Current development of heavy-duty manufacturing equipment. J. Mech. Eng., 46: 92-107.

Ge, H. and F. Gao, 2012. Type design for heavy-payload forging manipulators. Chinese J. Mech. Eng., 25: 197-205.

Ge, L. and X. Xu, 2015. A scheme design of cloud + end technology in demand side management. Am. J. Eng. Applied Sci., 8: 736-747.

DOI: 10.3844/ajeassp.2015.736.747

Giordana, F., V. Rognoni and G. Ruggieri, 1979. On the influence of measurement errors in the Kinematic analysis of cam. Mechanism Mach. Theory, 14: 327340. DOI: 10.1016/0094-114X(79)90019-3

Gruener, J.E., 2006. Lunar exploration (Presentation to ITEA Human Exploration Project Authors, November 2006, at Johnson Space Center). Houston, TX.

Gupta, P., A. Gupta and A. Asati, 2015. Ultra low power MUX based compressors for Wallace and Dadda multipliers in sub-threshold regime. Am. J. Eng. Applied Sci., 8: 702-716.

DOI: 10.3844/ajeassp.2015.702.716
Gusti, A.P. and Semin, 2016. The effect of vessel speed on fuel consumption and exhaust gas emissions. Am. J. Eng. Applied Sci., 9: 1046-1053. DOI: 10.3844/ajeassp.2016.1046.1053

Hain, K., 1971. Optimization of a cam mechanism to give good transmissibility maximal output angle of swing and minimal acceleration. J. Mechanisms, 6: 419-434. DOI: 10.1016/0022-2569(71)90044-9

Hassan, M., H. Mahjoub and M. Obed, 2012. Voicebased control of a DC servo motor. Am. J. Eng. Applied Sci., 5: 89-92.

DOI: 10.3844/ajeassp.2012.89.92

Hasan, S. and M.H. El-Naas, 2016. Optimization of a combined approach for the treatment of carbide slurry and capture of $\mathrm{CO}_{2}$. Am. J. Eng. Applied Sci., 9: 449-457. DOI: 10.3844/ajeassp.2016.449.457

Helmy, A.K. and G.S. El-Taweel, 2010. Neural network change detection model for satellite images using textural and spectral characteristics. Am. J. Eng. Applied Sci., 3: 604-610.

DOI: $10.3844 /$ ajeassp.2010.604.610

Hirun, W., 2016. Evaluation of interregional freight generation modelling methods by using nationwide commodity flow survey data. Am. J. Eng. Applied Sci., 9: 625-634. DOI: 10.3844/ajeassp.2016.625.634

Ho, C.Y.F., B.W.K. Ling, S.G. Blasi, Z.W. Chi and W.C. Siu, 2011. Single step optimal block matched motion estimation with motion vectors having arbitrary pixel precisions. Am. J. Eng. Applied Sci., 4: 448-460. DOI: 10.3844/ajeassp.2011.448.460

Huang, B., S.H. Masood, M. Nikzad, P.R. Venugopal and A. Arivazhagan, 2016. Dynamic mechanical properties of fused deposition modelling processed polyphenylsulfone material. Am. J. Eng. Applied Sci., 9: 1-11. DOI: 10.3844/ajeassp.2016.1.11

He, B., Z. Wang, Q. Li, H. Xie and R. Shen, 2013. An analytic method for the kinematics and dynamics of a multiple-backbone continuum robot. IJARS. DOI: $10.5772 / 54051$

Idarwazeh, S., 2011. Inverse discrete Fourier transformdiscrete Fourier transform techniques for generating and receiving spectrally efficient frequency division multiplexing signals. Am. J. Eng. Applied Sci., 4: 598-606. DOI: 10.3844/ajeassp.2011.598.606

Iqbal, M., 2016. An overview of Energy Loss Reduction (ELR) software used in Pakistan by WAPDA for calculating transformer overloading, line losses and energy losses. Am. J. Eng. Applied Sci., 9: 442-448. DOI: 10.3844/ajeassp.2016.442.448

Ismail, M.I.S., Y. Okamoto, A. Okada and Y. Uno, 2011. Experimental investigation on micro-welding of thin stainless steel sheet by fiber laser. Am. J. Eng. Applied Sci., 4: 314-320. DOI: 10.3844/ajeassp.2011.314.320

Jaber, A.A. and R. Bicker, 2016. Industrial robot fault detection based on statistical control chart. Am. J. Eng. Applied Sci., 9: 251-263.

DOI: 10.3844/ajeassp.2016.251.263 
Jafari, N., A. Alsadoon, C.P. Withana, A. Beg and A. Elchouemi, 2016. Designing a comprehensive security framework for smartphones and mobile devices. Am. J. Eng. Applied Sci., 9: 724-734. DOI: 10.3844/ajeassp.2016.724.734

Jalil, M.I.A. and J. Sampe, 2013. Experimental investigation of thermoelectric generator modules with different technique of cooling system. Am. J. Eng. Applied Sci., 6: 1-7.

DOI: 10.3844/ajeassp.2013.1.7

Jaoude, A.A. and K. El-Tawil, 2013. Analytic and nonlinear prognostic for vehicle suspension systems. Am. J. Eng. Applied Sci., 6: 42-56.

DOI: 10.3844/ajeassp.2013.42.56

Jarahi, H., 2016. Probabilistic seismic hazard deaggregation for Karaj City (Iran). Am. J. Eng. Applied Sci., 9: 520-529.

DOI: 10.3844/ajeassp.2016.520.529

Jarahi, H. and S. Seifilaleh, 2016. Rock fall hazard zonation in Haraz Highway. Am. J. Eng. Applied Sci., 9: 371-379.

DOI: 10.3844/ajeassp.2016.371.379

Jauhari, K., A. Widodo and I. Haryanto, 2016. Identification of a machine tool spindle critical frequency through modal and imbalance response analysis. Am. J. Eng. Applied Sci., 9: 213-221.

DOI: 10.3844/ajeassp.2016.213.221

Jiang, J., Q. Chen and S. Nimbalkar, 2016. Field data based method for predicting long-term settlements. Am. J. Eng. Applied Sci., 9: 466-476. DOI: 10.3844/ajeassp.2016.466.476

Jones, J.R. and J.E. Reeve, 1974. Dynamic Response of Cam Curves Based on Sinusoidal Segments. In: Cams and cam Mechanisms, Rees Jones, J. (Ed.), MEP, London and Birmingham, Alabama.

Kaewnai, S. and S. Wongwises, 2011. Improvement of the runner design of francis turbine using computational fluid dynamics. Am. J. Eng. Applied Sci., 4: 540-547.

DOI: 10.3844/ajeassp.2011.540.547

Khalifa, A.H.N., A.H. Jabbar and J.A. Muhsin, 2015. Effect of exhaust gas temperature on the performance of automobile adsorption airconditioner. Am. J. Eng. Applied Sci., 8: 575-581. DOI: 10.3844/ajeassp.2015.575.581

Khalil, R., 2015. Credibility of 3D volume computation using GIS for pit excavation and roadway constructions. Am. J. Eng. Applied Sci., 8: 434-442. DOI: 10.3844/ajeassp.2015.434.442

Kamble, V.G. and N. Kumar, 2016. Fabrication and tensile property analysis of polymer matrix composites of graphite and silicon carbide as fillers. Am. J. Eng. Applied Sci., 9: 17-30.

DOI: 10.3844/ajeassp.2016.17.30
Kazakov, V.V., V.I. Yusupov, V.N. Bagratashvili, A.I. Pavlikov and V.A. Kamensky, 2016. Control of bubble formation at the optical fiber tip by analyzing ultrasound acoustic waves. Am. J. Eng. Applied Sci., 9: 921-927.

DOI: 10.3844/ajeassp.2016.921.927

Kechiche, O.B.H.B., H.B.A. Sethom, H. Sammoud and I.S. Belkhodja, 2011. Optimized high-frequency signal injection based permanent magnet synchronous motor rotor position estimation applied to washing machines. Am. J. Eng. Applied Sci., 4: 390-399. DOI: 10.3844/ajeassp.2011.390.399

Koster, M.P., 1974. The Effects of Backlash and Shaft Flexibility on the Dynamic Behavior of a Cam Mechanism. In: Cams and Cam Mechanisms, Rees Jones, J. (Ed.), MEP, London and Birmingham, Alabama.

Kuli, I., T.M. Abu-Lebdeh, E.H. Fini and S.A. Hamoush, 2016. The use of nano-silica for improving mechanical properties of hardened cement paste. Am. J. Eng. Applied Sci., 9: 146-154. DOI: 10.3844/ajeassp.2016.146.154

Kumar, N.D., R.D. Ravali and PR. Srirekha, 2015. Design and realization of pre-amplifier and filters for on-board radar system. Am. J. Eng. Applied Sci., 8: 689-701. DOI: 10.3844/ajeassp.2015.689.701

Kunanoppadon, J., 2010. Thermal efficiency of a combined turbocharger set with gasoline engine. Am. J. Eng. Applied Sci., 3: 342-349. DOI: 10.3844/ajeassp.2010.342.349

Kwon, S., Y. Tani, H. Okubo and T. Shimomura, 2010. Fixed-star tracking attitude control of spacecraft using single-gimbal control moment gyros. Am. J. Eng. Applied Sci., 3: 49-55. DOI: 10.3844 /ajeassp.2010.49.55

Lamarre, A., E.H. Fini and T.M. Abu-Lebdeh, 2016. Investigating effects of water conditioning on the adhesion properties of crack sealant. Am. J. Eng. Applied Sci., 9: 178-186.

DOI: 10.3844/ajeassp.2016.178.186

Lee, B.J., 2013. Geometrical derivation of differential kinematics to calibrate model parameters of flexible manipulator. Int. J. Adv. Robotic Sys. DOI: $10.5772 / 55592$

Li, G. and D.S. Liu, 2010. Dynamic behavior of the forging manipulator under large amplitude compliance motion. J. Mech. Eng., 46: 21-28.

Li, R., B. Zhang, S. Xiu, H. Wang and L. Wang et al., 2015. Characterization of solid residues obtained from supercritical ethanol liquefaction of swine manure. Am. J. Eng. Applied Sci., 8: 465-470. DOI: 10.3844/ajeassp.2015.465.470

Lin, W., B. Li, X. Yang and D. Zhang, 2013. Modelling and control of inverse dynamics for a 5-DOF parallel kinematic polishing machine. Int. J. Adv. Robotic Sys. DOI: 10.5772/54966 
Liu, H., W. Zhou, X. Lai and S. Zhu, 2013. An efficient inverse kinematic algorithm for a PUMA560structured robot manipulator. IJARS.

DOI: $10.5772 / 56403$

Lubis, Z., A.N. Abdalla, Mortaza and R. Ghon, 2009. Mathematical modeling of the three phase induction motor couple to DC motor in hybrid electric vehicle. Am. J. Eng. Applied Sci., 2: 708-712.

DOI: 10.3844/ajeassp.2009.708.712

Madani, D.A. and A. Dababneh, 2016. Rapid entire body assessment: A literature review. Am. J. Eng. Applied Sci., 9: 107-118.

DOI: 10.3844/ajeassp.2016.107.118

Malomar, G.E.B., A. Gueye, C. Mbow, V.B. Traore and A.C. Beye, 2016. Numerical study of natural convection in a square porous cavity thermally modulated on both side walls. Am. J. Eng. Applied Sci., 9: 591-598.

DOI: 10.3844/ajeassp.2016.591.598

Mansour, M.A.A., 2016. Developing an anthropometric database for Saudi students and comparing Saudi dimensions relative to Turkish and Iranian peoples. Am. J. Eng. Applied Sci., 9: 547-557.

DOI: 10.3844/ajeassp.2016.547.557

Maraveas, C., Z.C. Fasoulakis and K.D. Tsavdaridis, 2015. A review of human induced vibrations on footbridges. Am. J. Eng. Applied Sci., 8: 422-433. DOI: 10.3844/ajeassp.2015.422.433

Marghany, M. and M. Hashim, 2009. Robust of doppler centroid for mapping sea surface current by using radar satellite data. Am. J. Eng. Applied Sci., 2: 781-788. DOI: 10.3844/ajeassp.2009.781.788

Martins, F.R., A.R. Gonçalves and E.B. Pereira, 2016. Observational study of wind shear in northeastern Brazil. Am. J. Eng. Applied Sci., 9: 484-504.

DOI: 10.3844/ajeassp.2016.484.504

Marzuki, M.A.L.B., M.H. Abd Halim and A.R.N. Mohamed, 2015. Determination of natural frequencies through modal and harmonic analysis of space frame race car chassis based on ANSYS. Am. J. Eng. Applied Sci., 8: 538-548.

DOI: 10.3844/ajeassp.2015.538.548

Mavukkandy, M.O., S. Chakraborty, T. Abbasi and S.A. Abbasi, 2016. A clean-green synthesis of platinum nanoparticles utilizing a pernicious weed lantana (Lantana Camara). Am. J. Eng. Applied Sci., 9: 8490. DOI: 10.3844/ajeassp.2016.84.90

Minghini, F., N. Tullini and F. Ascione, 2016. Updating Italian design guide CNR DT-205/2007 in view of recent research findings: Requirements for pultruded FRP profiles. Am. J. Eng. Applied Sci., 9: 702-712. DOI: 10.3844/ajeassp.2016.702.712

Moezi, N., D. Dideban and A. Ketabi, 2008. A novel integrated SET based inverter for nano power electronic applications. Am. J. Eng. Applied Sci., 1: 219-222. DOI: 10.3844/ajeassp.2008.219.222
Mohamed, M.A., A.Y. Tuama, M. Makhtar, M.K. Awang and M. Mamat, 2016. The effect of RSA exponential key growth on the multi-core computational resource. Am. J. Eng. Applied Sci., 9: 1054-1061. DOI: 10.3844/ajeassp.2016.1054.1061

Mohan, K.S.R., P. Jayabalan and A. Rajaraman, 2012. Properties of fly ash based coconut fiber composite. Am. J. Eng. Applied Sci., 5: 29-34.

DOI: 10.3844 /ajeassp.2012.29.34

Mohseni, E. and K.D. Tsavdaridis, 2016. Effect of nanoalumina on pore structure and durability of class $f$ fly ash self-compacting mortar. Am. J. Eng. Applied Sci., 9: 323-333. DOI: 10.3844/ajeassp.2016.323.333

Momani, M.A., T.A. Al Smadi, FM. Al Taweel and K.A. Ghaidan, 2011. GPS ionospheric total electron content and scintillation measurements during the October 2003 magnetic storm. Am. J. Eng. Applied Sci., 4: 301-306. DOI: 10.3844/ajeassp.2011.301.306

Momta, P.S., J.O. Omoboh and M.I. Odigi, 2015. Sedimentology and depositional environment of D2 sand in part of greater ughelli depobelt, onshore Niger Delta, Nigeria. Am. J. Eng. Applied Sci., 8: 556-566.

DOI: 10.3844 /ajeassp.2015.556.566

Mondal, R., S. Sahoo and C.S. Rout, 2016. Mixed nickel cobalt manganese oxide nanorods for supercapacitor application. Am. J. Eng. Applied Sci., 9: 540-546. DOI: 10.3844/ajeassp.2016.540.546

Montgomery, J., T.M. Abu-Lebdeh, S.A. Hamoush and M. Picornell, 2016. Effect of nano-silica on the compressive strength of harden cement paste at different stages of hydration. Am. J. Eng. Applied Sci., 9: 166-177.

DOI: 10.3844/ajeassp.2016.166.177

Moretti, M.L., 2015. Seismic design of masonry and reinforced concrete infilled frames: A comprehensive overview. Am. J. Eng. Applied Sci., 8: 748-766. DOI: 10.3844/ajeassp.2015.748.766

Morse, A., M.M. Mansfield, R.M. Alley, H.A. Kerr and R.B. Bucinell, 2016b. Traction enhancing products affect maximum torque at the shoe-floor interface: A potential increased risk of ACL injury. Am. J. Eng. Applied Sci., 9: 889-893.

DOI: $10.3844 /$ ajeassp.2016.889.893

Moubarek, T. and A. Gharsallah, 2016. A six-port reflectometer calibration using Wilkinson power divider. Am. J. Eng. Applied Sci., 9: 274-280.

DOI: 10.3844/ajeassp.2016.274.280

Nabilou, A., 2016a. Effect of parameters of selection and replacement drilling bits based on geo-mechanical factors: (Case study: Gas and oil reservoir in the Southwest of Iran). Am. J. Eng. Applied Sci., 9: 380-395. DOI: 10.3844/ajeassp.2016.380.395 
Nabilou, A., 2016b. Study of the parameters of Steam Assisted Gravity Drainage (SAGD) method for enhanced oil recovery in a heavy oil fractured carbonate reservoir. Am. J. Eng. Applied Sci., 9: 647-658. DOI: 10.3844/ajeassp.2016.647.658

Nachiengtai, T., W. Chim-Oye, S. Teachavorasinskun and W. Sa-Ngiamvibool, 2008. Identification of shear band using elastic shear wave propagation. Am. J. Eng. Applied Sci., 1: 188-191.

DOI: 10.3844/ajeassp.2008.188.191

Nahas, R. and S.P. Kozaitis, 2014. Metric for the fusion of synthetic and real imagery from multimodal sensors. Am. J. Eng. Applied Sci., 7: 355-362.

DOI: 10.3844/ajeassp.2014.355.362

Nandhakumar, S., V. Selladurai and S. Sekar, 2009. Numerical investigation of an industrial robot arm control problem using haar wavelet series. Am. J. Eng. Applied Sci., 2: 584-589.

DOI: 10.3844/ajeassp.2009.584.589

Ng, K.C., M.Z. Yusoff, K. Munisamy, H. Hasini and N.H. Shuaib, 2008. Time-marching method for computations of high-speed compressible flow on structured and unstructured grid. Am. J. Eng. Applied Sci., 1: 89-94.

DOI: 10.3844/ajeassp.2008.89.94

Obaiys, S.J., Z. Abbas, N.M.A. Nik Long, A.F. Ahmad and A. Ahmedov et al., 2016. On the general solution of first-kind hypersingular integral equations. Am. J. Eng. Applied Sci., 9: 195-201. DOI: 10.3844/ajeassp.2016.195.201

Odeh, S., R. Faqeh, L. Abu Eid and N. Shamasneh, 2009. Vision-based obstacle avoidance of mobile robot using quantized spatial model. Am. J. Eng. Applied Sci., 2: 611-619.

DOI: 10.3844/ajeassp.2009.611.619

Ong, A.T., A. Mustapha, Z.B. Ibrahim, S. Ramli and B.C. Eong, 2015. Real-time automatic inspection system for the classification of PCB flux defects. Am. J. Eng. Applied Sci., 8: 504-518. DOI: 10.3844/ajeassp.2015.504.518

Opafunso, Z.O., I.I. Ozigis and I.A. Adetunde, 2009. Pneumatic and hydraulic systems in coal fluidized bed combustor. Am. J. Eng. Applied Sci., 2: 88-95. DOI: 10.3844/ajeassp.2009.88.95

Orlando, N. and E. Benvenuti, 2016. Advanced XFEM simulation of pull-out and debonding of steel bars and FRP-reinforcements in concrete beams. Am. J. Eng. Applied Sci., 9: 746-754.

DOI: 10.3844/ajeassp.2016.746.754

Pannirselvam, N., P.N. Raghunath and K. Suguna, 2008. Neural network for performance of glass fibre reinforced polymer plated RC beams. Am. J. Eng. Applied Sci., 1: 82-88.

DOI: $10.3844 /$ ajeassp.2008.82.88
Pattanasethanon, S., 2010. The solar tracking system by using digital solar position sensor. Am. J. Eng. Applied Sci., 3: 678-682. DOI: 10.3844/ajeassp.2010.678.682

Pérez-de León, G., V.E. Lamberti, R.D. Seals, T.M. Abu-Lebdeh and S.A. Hamoush, 2016. Gas atomization of molten metal: Part I. Numerical modeling conception. Am. J. Eng. Applied Sci., 9: 303-322. DOI: 10.3844/ajeassp.2016.303.322

Padula, F. and V. Perdereau, 2013. An on-line path planner for industrial manipulators. Int. J. Adv. Robotic Sys. DOI: 10.5772/55063

Perumaal, S. and N. Jawahar, 2013. Automated trajectory planner of industrial robot for pick-andplace task. IJARS. DOI: 10.5772/53940

Petrescu, F. and R. Petrescu, 1995a. Contributions to optimization of the polynomial motion laws of the stick from the internal combustion engine distribution mechanism. Bucharest, 1: 249-256.

Petrescu, F. and R. Petrescu, 1995b. Contributions to the synthesis of internal combustion engine distribution mechanisms. Bucharest, 1: 257-264.

Petrescu, F. and R. Petrescu, 1997a. Dynamics of cam mechanisms (exemplified on the classic distribution mechanism). Bucharest, 3: 353-358.

Petrescu, F. and R. Petrescu, 1997b. Contributions to the synthesis of the distribution mechanisms of internal combustion engines with a Cartesian coordinate method. Bucharest, 3: 359-364.

Petrescu, F. and R. Petrescu, 1997c. Contributions to maximizing polynomial laws for the active stroke of the distribution mechanism from internal combustion engines. Bucharest, 3: 365-370.

Petrescu, F. and R. Petrescu, 2000a. Synthesis of distribution mechanisms by the rectangular (Cartesian) coordinate method. Proceedings of the 8th National Conference on International Participation, (CIP' 00), Craiova, Romania, pp: 297-302.

Petrescu, F. and R. Petrescu, 2000b. The design (synthesis) of cams using the polar coordinate method (triangle method). Proceedings of the 8th National Conference on International Participation, (CIP' 00), Craiova, Romania, pp: 291-296.

Petrescu, F. and R. Petrescu, 2002a. Motion laws for cams. Proceedings of the International Computer Assisted Design, National Symposium with Participation, (SNP' 02), Braşov, pp: 321-326.

Petrescu, F. and R. Petrescu, 2002b. Camshaft dynamics elements. Proceedings of the International Computer Assisted Design, National Participation Symposium, (SNP' 02), Braşov, pp: 327-332.

Petrescu, F. and R. Petrescu, 2003. Some elements regarding the improvement of the engine design. Proceedings of the National Symposium, Descriptive Geometry, Technical Graphics and Design, (GTD' 03), Braşov, pp: 353-358. 
Petrescu, F. and R. Petrescu, 2005a. The cam design for a better efficiency. Proceedings of the International Conference on Engineering Graphics and Design, (EGD’ 05), Bucharest, pp: 245-248.

Petrescu, F. and R. Petrescu, 2005b. Contributions at the dynamics of cams. Proceedings of the 9th IFToMM International Symposium on Theory of Machines and Mechanisms, (TMM' 05), Bucharest, Romania, pp: $123-128$.

Petrescu, F. and R. Petrescu, 2005c. Determining the dynamic efficiency of cams. Proceedings of the 9th IFToMM International Symposium on Theory of Machines and Mechanisms, (TMM' 05), Bucharest, Romania, pp: 129-134.

Petrescu, F. and R. Petrescu, 2005d. An original internal combustion engine. Proceedings of the 9th IFToMM International Symposium on Theory of Machines and Mechanisms, (TMM' 05), Bucharest, Romania, pp: $135-140$.

Petrescu, F. and R. Petrescu, 2005e. Determining the mechanical efficiency of Otto engine's mechanism. Proceedings of the 9th IFToMM International Symposium on Theory of Machines and Mechanisms, (TMM 05), Bucharest, Romania, pp: 141-146.

Petrescu, F.I. and R.V. Petrescu, 2011a. Mechanical Systems, Serial and Parallel (Romanian). 1st Edn., LULU Publisher, London, UK, pp: 124.

Petrescu, F.I.T., Petrescu, R.V., 2011b. Trenuri Planetare. Createspace Independent Pub., 104 pages, ISBN-13: 978-1468030419.

Petrescu, F.I. and R.V. Petrescu, 2012a. Kinematics of the planar quadrilateral mechanism. ENGEVISTA, 14: $345-348$.

Petrescu, F.I. and R.V. Petrescu, 2012b. MecatronicaSisteme Seriale si Paralele. 1st Edn., Create Space Publisher, USA, pp: 128.

Petrescu, F.I. and R.V. Petrescu, 2013a. Cinematics of the 3R dyad. ENGEVISTA, 15: 118-124.

Petrescu, F.I.T. and R.V. Petrescu, 2013b. Forces and efficiency of cams. Int. Rev. Mech. Eng., 7: 507-511.

Petrescu, F.I.T. and R.V. Petrescu, 2013c. Cams with high efficiency. Int. Rev. Mech. Eng., 7: 599-606.

Petrescu, F.I.T. and R.V. Petrescu, 2013d. An algorithm for setting the dynamic parameters of the classic distribution mechanism. Int. Rev. Modell. Simulat., 6: 1637-1641.

Petrescu, F.I.T. and R.V. Petrescu, 2013e. Dynamic synthesis of the rotary cam and translated tappet with roll. Int. Rev. Modell. Simulat., 6: 600-607.

Petrescu, F.I.T. and R.V. Petrescu, 2014a. Parallel moving mechanical systems. Independent $\mathrm{J}$. Manage. Product., 5: 564-580.

Petrescu, F.I.T. and R.V. Petrescu, 2014b. Cam gears dynamics in the classic distribution. Independent $\mathrm{J}$. Manage. Product., 5: 166-185.
Petrescu, F.I.T. and R.V. Petrescu, 2014c. Highefficiency gears synthesis by avoid the interferences. Independent J. Manage. Product., 5: 275-298.

Petrescu, F.I.T. and R.V. Petrescu, 2014d. Gear design. J. ENGEVISTA, 16: 313-328.

Petrescu, F.I.T. and R.V. Petrescu, 2014e. Kinetostatic of the $3 \mathrm{R}$ dyad (or $2 \mathrm{R}$ module). J. ENGEVISTA, 16: 314-321.

Petrescu, F.I.T. and R.V. Petrescu, 2014f. Balancing Otto engines. Int. Rev. Mech. Eng., 8: 473-480.

Petrescu, F.I.T. and R.V. Petrescu, 2014g. Machine equations to the classical distribution. Int. Rev. Mech. Eng., 8: 309-316.

Petrescu, F.I.T. and R.V. Petrescu, 2014h. Forces of internal combustion heat engines. Int. Rev. Modell. Simulat., 7: 206-212.

Petrescu, F.I.T. and R.V. Petrescu, 2014i. Determination of the yield of internal combustion thermal engines. Int. Rev. Mech. Eng., 8: 62-67.

Petrescu, F.I.T. and R.V. Petrescu, 2015a. Forces at the main mechanism of a railbound forging manipulator. Independent J. Manage. Product., 6: 904-921.

Petrescu, F.I.T. and R.V. Petrescu, 2015b. Kinematics at the main mechanism of a railbound forging manipulator. Independent J. Manage. Product., 6: 711-729.

Petrescu, F.I.T. and R.V. Petrescu, 2015c. Machine motion equations. Independent J. Manage. Product., 6: 773-802.

Petrescu F.I.T. and R.V. Petrescu, 2015d. Presenting a railbound forging manipulator. Applied Mech. Mater., 762: 219-224.

Petrescu, F.I.T. and R.V. Petrescu, 2015e. About the anthropomorphic robots. J. ENGEVISTA, 17: 1-15.

Petrescu, F.I. and R.V. Petrescu, 2016a. Parallel moving mechanical systems kinematics. ENGEVISTA, 18: 455-491.

Petrescu, F.I. and R.V. Petrescu, 2016b. Direct and inverse kinematics to the anthropomorphic robots. ENGEVISTA, 18: 109-124.

Petrescu, F.I. and R.V. Petrescu, 2016c. Dynamic cinematic to a structure 2R. Revista Geintec-Gestao Inovacao E Tecnol., 6: 3143-3154.

Petrescu, FIT. and R.V. Petrescu, 2016d. An Otto engine dynamic model. Independent J. Manage. Product., 7: 038-048

Petrescu, R.V.V., F.I.T. Petrescu, E. Maghiari and I. Cristian, 2000. Evolution of the teaching of descriptive geometry course at higher level in the last 200 years. Proceedings of the National Conference with International Participation, (CIP' 00), Craiova, Romania, pp: 315-320.

Petrescu, R.V., R. Aversa, A. Apicella and F.I. Petrescu, 2016. Future medicine services robotics. Am. J. Eng. Applied Sci., 9: 1062-1087.

DOI: 10.3844/ajeassp.2016.1062.1087 
Petrescu, F.I., B. Grecu, A. Comanescu and R.V. Petrescu, 2009. Some mechanical design elements. Proceeding of the International Conference on Computational Mechanics and Virtual Engineering, (MVE' 09), Braşov, pp: 520-525.

Petrescu, F.I.T., 2008. Ph.D. Thesis, „Theoretical and Applied Contributions About the Dynamic of Planar Mechanisms with Superior Linkages”. Bucharest Polytechnic University.

Petrescu, F.I.T., 2011. Teoria Mecanismelor si a Masinilor: Curs Si Aplicatii. 1st Edn., CreateSpace Independent Publishing Platform. ISBN-10: 1468015826. pp: 432.

Petrescu, F.I.T., 2015a. Geometrical synthesis of the distribution mechanisms. Am. J. Eng. Applied Sci., 8: 63-81. DOI: 10.3844/ajeassp.2015.63.81

Petrescu, F.I.T., 2015b. Machine motion equations at the internal combustion heat engines. Am. J. Eng. Applied Sci., 8: 127-137. DOI: 10.3844/ajeassp.2015.127.137

Petrescu, F.I.T., A. Apicella, A. Raffaella, RV. Petrescu and J.K. Calautit et al., 2016. Something about the mechanical moment of inertia. Am. J. Applied Sci., 13: 1085-1090. DOI: 10.3844/ajassp.2016.1085.1090

Petrescu, R.V., R. Aversa, B. Akash, R. Bucinell and J. Corchado et al., 2017a. Yield at thermal engines internal combustion. Am. J. Eng. Applied Sci., 10: 243-251. DOI: 10.3844/ajeassp.2017.243.251

Petrescu, R.V., R. Aversa, B. Akash, B. Ronald and J. Corchado et al., 2017b. Velocities and accelerations at the 3R mechatronic systems. Am. J. Eng. Applied Sci., 10: 252-263. DOI: 10.3844/ajeassp.2017.252.263

Petrescu, R.V., R. Aversa, B. Akash, R. Bucinell and J. Corchado et al., 2017c. Anthropomorphic solid structures n-r kinematics. Am. J. Eng. Applied Sci., 10: 279-291. DOI: 10.3844/ajeassp.2017.279.291

Petrescu, R.V., R. Aversa, B. Akash, R. Bucinell and J. Corchado et al., 2017d. Inverse kinematics at the anthropomorphic robots, by a trigonometric method. Am. J. Eng. Applied Sci., 10: 394-411. DOI: 10.3844/ajeassp.2017.394.411

Petrescu, R.V., R. Aversa, B. Akash, R. Bucinell and J. Corchado et al., 2017e. Forces at internal combustion engines. Am. J. Eng. Applied Sci., 10: 382-393. DOI: 10.3844/ajeassp.2017.382.393

Petrescu, R.V., R. Aversa, B. Akash, R. Bucinell and J. Corchado et al., 2017f. Gears-Part I. Am. J. Eng. Applied Sci., 10: 457-472.

DOI: 10.3844/ajeassp.2017.457.472

Petrescu, R.V., R. Aversa, B. Akash, R. Bucinell and J. Corchado et al., 2017g. Gears-part II. Am. J. Eng. Applied Sci., 10: 473-483.

DOI: 10.3844/ajeassp.2017.473.483

Petrescu, R.V., R. Aversa, B. Akash, R. Bucinell and J. Corchado et al., 2017h. Cam-gears forces, velocities, powers and efficiency. Am. J. Eng. Applied Sci., 10: 491-505. DOI: 10.3844/ajeassp.2017.491.505
Petrescu, R.V., R. Aversa, B. Akash, R. Bucinell and J. Corchado et al., 2017i. Dynamics of mechanisms with cams illustrated in the classical distribution. Am. J. Eng. Applied Sci., 10: 551-567.

DOI: 10.3844/ajeassp.2017.551.567

Petrescu, R.V., R. Aversa, B. Akash, R. Bucinell and J. Corchado et al., 2017j. Testing by non-destructive control. Am. J. Eng. Applied Sci., 10: 568-583. DOI: 10.3844/ajeassp.2017.568.583

Petrescu, R.V., R. Aversa, A. Apicella and F.I.T. Petrescu, 2017k. Transportation engineering. Am. J. Eng. Applied Sci., 10: 685-702.

DOI: 10.3844/ajeassp.2017.685.702

Petrescu, R.V., R. Aversa, S. Kozaitis, A. Apicella and F.I.T. Petrescu, 20171. The quality of transport and environmental protection, part I. Am. J. Eng. Applied Sci., 10: 738-755. DOI: 10.3844/ajeassp.2017.738.755

Petrescu, R.V., R. Aversa, B. Akash, R. Bucinell and J. Corchado et al., 2017m. Modern propulsions for aerospace-a review. J. Aircraft Spacecraft Technol., 1: 1-8. DOI: 10.3844/jastsp.2017.1.8

Petrescu, R.V., R. Aversa, B. Akash, R. Bucinell and J. Corchado et al., 2017n. Modern propulsions for aerospace-part II. J. Aircraft Spacecraft Technol., 1: 9-17. DOI: 10.3844/jastsp.2017.9.17

Petrescu, R.V., R. Aversa, B. Akash, R. Bucinell and J. Corchado et al., 2017o. History of aviation-a short review. J. Aircraft Spacecraft Technol., 1: 30-49. DOI: 10.3844/jastsp.2017.30.49

Petrescu, R.V., R. Aversa, B. Akash, R. Bucinell and J. Corchado et al., 2017p. Lockheed martin-a short review. J. Aircraft Spacecraft Technol., 1: 50-68. DOI: 10.3844/jastsp.2017.50.68

Petrescu, R.V., R. Aversa, B. Akash, J. Corchado and F. Berto et al., 2017q. Our universe. J. Aircraft Spacecraft Technol., 1: 69-79. DOI: 10.3844/jastsp.2017.69.79

Petrescu, R.V., R. Aversa, B. Akash, J. Corchado and F. Berto et al., 2017r. What is a UFO? J. Aircraft Spacecraft Technol., 1: 80-90. DOI: $10.3844 /$ jastsp.2017.80.90

Petrescu, R.V., R. Aversa, B. Akash, J. Corchado and F. Berto et al., 2017s. About bell helicopter FCX-001 concept aircraft-a short review. J. Aircraft Spacecraft Technol., 1: 91-96. DOI: 10.3844/jastsp.2017.91.96

Petrescu, R.V., R. Aversa, B. Akash, J. Corchado and F. Berto et al., 2017t. Home at airbus. J. Aircraft Spacecraft Technol., 1: 97-118.

DOI: 10.3844/jastsp.2017.97.118

Petrescu, R.V., R. Aversa, B. Akash, J. Corchado and F. Berto et al., 2017u. Airlander. J. Aircraft Spacecraft Technol., 1: 119-148.

DOI: $10.3844 /$ jastsp.2017.119.148 
Petrescu, R.V., R. Aversa, B. Akash, J. Corchado and F. Berto et al., 2017v. When boeing is dreaming-a review. J. Aircraft Spacecraft Technol., 1: 149-161. DOI: $10.3844 /$ jastsp.2017.149.161

Petrescu, R.V., R. Aversa, B. Akash, J. Corchado and F. Berto et al., 2017w. About Northrop Grumman. J. Aircraft Spacecraft Technol., 1: 162-185.

DOI: $10.3844 /$ jastsp.2017.162.185

Petrescu, R.V., R. Aversa, B. Akash, J. Corchado and F. Berto et al., 2017x. Some special aircraft. J. Aircraft Spacecraft Technol., 1: 186-203. DOI: $10.3844 /$ jastsp.2017.186.203

Petrescu, R.V., R. Aversa, B. Akash, J. Corchado and F. Berto et al., 2017y. About helicopters. J. Aircraft Spacecraft Technol., 1: 204-223. DOI: 10.3844 /jastsp.2017.204.223

Petrescu, R.V., R. Aversa, B. Akash, F. Berto and A. Apicella et al., 2017z. The modern flight. J. Aircraft Spacecraft Technol., 1: 224-233. DOI: 10.3844/jastsp.2017.224.233

Petrescu, R.V., R. Aversa, B. Akash, F. Berto and A. Apicella et al., 2017aa. Sustainable energy for aerospace vessels. J. Aircraft Spacecraft Technol., 1: 234-240. DOI: 10.3844/jastsp.2017.234.240

Petrescu, R.V., R. Aversa, B. Akash, F. Berto and A. Apicella et al., 2017ab. Unmanned helicopters. J. Aircraft Spacecraft Technol., 1: 241-248.

DOI: $10.3844 /$ jastsp.2017.241.248

Petrescu, R.V., R. Aversa, B. Akash, F. Berto and A. Apicella et al., 2017ac. Project HARP. J. Aircraft Spacecraft Technol., 1: 249-257. DOI: 10.3844 /jastsp.2017.249.257

Petrescu, R.V., R. Aversa, B. Akash, F. Berto and A. Apicella et al., 2017ad. Presentation of Romanian engineers who contributed to the development of global aeronautics-part I. J. Aircraft Spacecraft Technol., 1: 258-271. DOI: $10.3844 /$ jastsp.2017.258.271

Petrescu, R.V., R. Aversa, B. Akash, F. Berto and A. Apicella et al., 2017ae. A first-class ticket to the planet mars, please. J. Aircraft Spacecraft Technol., 1: 272-281. DOI: 10.3844/jastsp.2017.272.281

Petrescu, R.V., R. Aversa, A. Apicella, M.M. Mirsayar and S. Kozaitis et al., 2018a. NASA started a propeller set on board voyager 1 after 37 years of break. Am. J. Eng. Applied Sci., 11: 66-77. DOI: 10.3844 /ajeassp.2018.66.77

Petrescu, R.V., R. Aversa, A. Apicella, M.M. Mirsayar and S. Kozaitis et al., 2018b. There is life on mars? Am. J. Eng. Applied Sci., 11: 78-91.

DOI: 10.3844/ajeassp.2018.78.91

Petrescu, R.V., R. Aversa, A. Apicella and F.I.T. Petrescu, 2018c. Friendly environmental transport. Am. J. Eng. Applied Sci., 11: 154-165.

DOI: 10.3844/ajeassp.2018.154.165
Petrescu, R.V., R. Aversa, B. Akash, T.M. Abu-Lebdeh and A. Apicella et al., 2018d. Buses running on gas. Am. J. Eng. Applied Sci., 11: 186-201.

DOI: 10.3844/ajeassp.2018.186.201

Petrescu, R.V., R. Aversa, B. Akash, T.M. Abu-Lebdeh and A. Apicella et al., 2018e. Some aspects of the structure of planar mechanisms. Am. J. Eng. Applied Sci., 11: 245-259.

DOI: 10.3844/ajeassp.2018.245.259

Petrescu, RV., R. Aversa, T.M. Abu-Lebdeh, A. Apicella and F.I.T. Petrescu, 2018f. The forces of a simple carrier manipulator. Am. J. Eng. Applied Sci., 11: 260-272. DOI: 10.3844/ajeassp.2018.260.272

Petrescu, RV., R. Aversa, T.M. Abu-Lebdeh, A. Apicella and F.I.T. Petrescu, 2018g. The dynamics of the otto engine. Am. J. Eng. Applied Sci., 11: 273-287. DOI: 10.3844/ajeassp.2018.273.287

Petrescu, RV., R. Aversa, T.M. Abu-Lebdeh, A. Apicella and F.I.T. Petrescu, 2018h. NASA satellites help us to quickly detect forest fires. Am. J. Eng. Applied Sci., 11: 288-296.

DOI: 10.3844/ajeassp.2018.288.296

Petrescu, RV., R. Aversa, T.M. Abu-Lebdeh, A. Apicella and F.I.T. Petrescu, 2018i. Kinematics of a mechanism with a triad. Am. J. Eng. Applied Sci., 11: 297-308. DOI: 10.3844/ajeassp.2018.297.308

Petrescu, R.V., R. Aversa, A. Apicella and F.I.T. Petrescu, 2018j. Romanian engineering "on the wings of the wind". J. Aircraft Spacecraft Technol., 2: 1-18. DOI: $10.3844 /$ jastsp.2018.1.18

Petrescu, R.V., R. Aversa, A. Apicella and F.I.T. Petrescu, 2018k. NASA Data used to discover eighth planet circling distant star. J. Aircraft Spacecraft Technol., 2: 19-30.

DOI: 10.3844 /jastsp.2018.19.30

Petrescu, R.V., R. Aversa, A. Apicella and F.I.T. Petrescu, 20181. NASA has found the most distant black hole. J. Aircraft Spacecraft Technol., 2: 31-39. DOI: 10.3844 /jastsp.2018.31.39

Petrescu, R.V., R. Aversa, A. Apicella and F.I.T. Petrescu, 2018m. Nasa selects concepts for a new mission to titan, the moon of saturn. J. Aircraft Spacecraft Technol., 2: 40-52. DOI: 10.3844 /jastsp.2018.40.52

Petrescu, R.V., R. Aversa, A. Apicella and F.I.T. Petrescu, 2018n. NASA sees first in 2018 the direct proof of ozone hole recovery. J. Aircraft Spacecraft Technol., 2: 53-64. DOI: 10.3844/jastsp.2018.53.64

Petrescu, R.V.V., 2012. Projective and descriptive geometry course. UPB.

Pisello, A.L., G. Pignatta, C. Piselli, V.L. Castaldo and F. Cotana, 2016. Investigating the dynamic thermal behavior of building envelope in summer conditions by means of in-field continuous monitoring. Am. J. Eng. Applied Sci., 9: 505-519.

DOI: $10.3844 /$ ajeassp.2016.505.519 
Pourmahmoud, N., 2008. Rarefied gas flow modeling inside rotating circular cylinder. Am. J. Eng. Applied Sci., 1: 62-65.

DOI: 10.3844/ajeassp.2008.62.65

Pravettoni, M., C.S.P. Lòpez and R.P. Kenny, 2016. Impact of the edges of a backside diffusive reflector on the external quantum efficiency of luminescent solar concentrators: Experimental and computational approach. Am. J. Eng. Applied Sci., 9: 53-63.

DOI: 10.3844 /ajeassp.2016.53.63

Qutbodin, K., 2010. Merging autopilot/flight control and navigation-flight management systems. Am. J. Eng. Applied Sci., 3: 629-630.

DOI: 10.3844/ajeassp.2010.629.630

Rajbhandari, S., Z. Ghassemlooy and M. Angelova, 2011. The performance of a dual header pulse interval modulation in the presence of artificial light interferences in an indoor optical wireless communications channel with wavelet denoising. Am. J. Eng. Applied Sci., 4: 513-519.

DOI: 10.3844/ajeassp.2011.513.519

Rajput, R.S., S. Pandey and S. Bhadauria, 2016. Correlation of biodiversity of algal genera with special reference to the waste water effluents from industries. Am. J. Eng. Applied Sci., 9: 1127-1133. DOI: 10.3844/ajeassp.2016.1127.1133

Rajupillai, K., S. Palaniammal and K. Bommuraju, 2015. Computational intelligence and application of frame theory in communication systems. Am. J. Eng. Applied Sci., 8: 633-637.

DOI: 10.3844/ajeassp.2015.633.637

Raptis, K.G., G.A. Papadopoulos, T.N. Costopoulos and A.D. Tsolakis, 2011. Experimental study of load sharing in roller-bearing contact by caustics and photoelasticity. Am. J. Eng. Applied Sci., 4: 294300. DOI: 10.3844/ajeassp.2011.294.300

Rama, G., D. Marinkovic and M. Zehn, 2016. Efficient co-rotational 3-node shell element. Am. J. Eng. Applied Sci., 9: 420-431.

DOI: 10.3844/ajeassp.2016.420.431

Rea, P. and E. Ottaviano, 2016. Analysis and mechanical design solutions for sit-to-stand assisting devices. Am. J. Eng. Applied Sci., 9: 1134-1143.

DOI: 10.3844/ajeassp.2016.1134.1143

Rhode-Barbarigos, L., V. Charpentier, S. Adriaenssens and O. Baverel, 2015. Dialectic form finding of structurally integrated adaptive structures. Am. J. Eng. Applied Sci., 8: 443-454.

DOI: 10.3844/ajeassp.2015.443.454

Riccio, A., U. Caruso, A. Raimondo and A. Sellitto, 2016a. Robustness of XFEM method for the simulation of cracks propagation in fracture mechanics problems. Am. J. Eng. Applied Sci., 9: 599-610. DOI: 10.3844/ajeassp.2016.599.610
Riccio, A., R. Cristiano and S. Saputo, 2016b. A brief introduction to the bird strike numerical simulation. Am. J. Eng. Applied Sci., 9: 946-950. DOI: 10.3844/ajeassp.2016.946.950

Rich, F. and M.A. Badar, 2016. Statistical analysis of auto dilution $\mathrm{Vs}$ manual dilution process in inductively coupled plasma spectrometer tests. Am. J. Eng. Applied Sci., 9: 611-624. DOI: 10.3844/ajeassp.2016.611.624

Rohit, K. and S. Dixit, 2016. Mechanical properties of waste Biaxially Oriented Polypropylene metallized films (BOPP), LLDPE: LDPE films with sisal fibres. Am. J. Eng. Applied Sci., 9: 913-920. DOI: 10.3844/ajeassp.2016.913.920

Rulkov, N.F., A.M. Hunt, P.N. Rulkov and A.G. Maksimov, 2016. Quantization of map-based neuronal model for embedded simulations of neurobiological networks in real-time. Am. J. Eng. Applied Sci., 9: 973-984. DOI: 10.3844/ajeassp.2016.973.984

Saikia, A. and N. Karak, 2016. Castor oil based epoxy/clay nanocomposite for advanced applications. Am. J. Eng. Applied Sci., 9: 31-40. DOI: 10.3844/ajeassp.2016.31.40

Sallami, A., N. Zanzouri and M. Ksouri, 2016. Robust diagnosis of a DC motor by bond graph approach. Am. J. Eng. Applied Sci., 9: 432-438. DOI: 10.3844/ajeassp.2016.432.438

Samantaray, K.S., S. Sahoo and C.S. Rout, 2016. Hydrothermal synthesis of CuWO4-reduced graphene oxide hybrids and supercapacitor application. Am. J. Eng. Applied Sci., 9: 584-590. DOI: 10.3844/ajeassp.2016.584.590

Santos, F.A. and C. Bedon, 2016. Preliminary experimental and finite-element numerical assessment of the structural performance of SMAreinforced GFRP systems. Am. J. Eng. Applied Sci., 9: 692-701. DOI: 10.3844/ajeassp.2016.692.701

Sava, I., 1970. Contributions to dynamics and optimization of income mechanism synthesis. Ph.D. Thesis, I.P.B.

Semin, A.R. Ismail and R.A. Bakar, 2009a. Combustion temperature effect of diesel engine convert to compressed natural gas engine. Am. J. Eng. Applied Sci., 2: 212-216. DOI: 10.3844/ajeassp.2009.212.216

Semin, A.R. Ismail and R.A. Bakar, 2009b. Effect of diesel engine converted to sequential port injection compressed natural gas engine on the cylinder pressure Vs crank angle in variation engine speeds. Am. J. Eng. Applied Sci., 2: 154-159. DOI: 10.3844 /ajeassp.2009.154.159

Semin S., A.R. Ismail and R.A. Bakar, 2009c. Diesel engine convert to port injection $\mathrm{CNG}$ engine using gaseous injector nozzle multi holes geometries improvement: A review. Am. J. Eng. Applied Sci., 2: 268-278. DOI: 10.3844/ajeassp.2009.268.278 
Semin and R.A. Bakar, 2008. A technical review of compressed natural gas as an alternative fuel for internal combustion engines. Am. J. Eng. Applied Sci., 1: 302-311.

DOI: 10.3844/ajeassp.2008.302.311

Sepúlveda, J.A.M., 2016. Outlook of municipal solid waste in Bogota (Colombia). Am. J. Eng. Applied Sci., 9: 477-483.

DOI: $10.3844 /$ ajeassp.2016.477.483

Serebrennikov, A., D. Serebrennikov and Z. Hakimov, 2016. Polyethylene pipeline bending stresses at an installation. Am. J. Eng. Applied Sci., 9: 350-355. DOI: 10.3844/ajeassp.2016.350.355

Shanmugam, K., 2016. Flow dynamic behavior of fish oil/silver nitrate solution in mini-channel, effect of alkane addition on flow pattern and interfacial tension. Am. J. Eng. Applied Sci., 9: 236-250. DOI: 10.3844/ajeassp.2016.236.250

Shruti, 2016. Comparison in cover media under stegnography: Digital media by hide and seek approach. Am. J. Eng. Applied Sci., 9: 297-302. DOI: 10.3844/ajeassp.2016.297.302

Stavridou, N., E. Efthymiou and C.C. Baniotopoulos, 2015a. Welded connections of wind turbine towers under fatigue loading: Finite element analysis and comparative study. Am. J. Eng. Applied Sci., 8: 489-503. DOI: 10.3844/ajeassp.2015.489.503

Stavridou, N., E. Efthymiou and C.C. Baniotopoulos, 2015b. Verification of anchoring in foundations of wind turbine towers. Am. J. Eng. Applied Sci., 8: 717-729. DOI: 10.3844/ajeassp.2015.717.729

Suarez, L., T.M. Abu-Lebdeh, M. Picornell and S.A. Hamoush, 2016. Investigating the role of fly ash and silica fume in the cement hydration process. Am. J. Eng. Applied Sci., 9: 134-145.

DOI: 10.3844/ajeassp.2016.134.145

Syahrullah, O.I. and N. Sinaga, 2016. Optimization and prediction of motorcycle injection system performance with feed-forward back-propagation method Artificial Neural Network (ANN). Am. J. Eng. Applied Sci., 9: 222-235.

DOI: 10.3844/ajeassp.2016.222.235

Sylvester, O., I. Bibobra and O.N. Ogbon, 2015a. Well test and PTA for reservoir characterization of key properties. Am. J. Eng. Applied Sci., 8: 638-647. DOI: 10.3844/ajeassp.2015.638.647

Sylvester, O., I. Bibobra and O. Augustina, 2015b. Report on the evaluation of Ugua $\mathrm{J} 2$ and $\mathrm{J} 3$ reservoir performance. Am. J. Eng. Applied Sci., 8: 678-688. DOI: 10.3844/ajeassp.2015.678.688

Taher, S.A., R. Hematti and M. Nemati, 2008. Comparison of different control strategies in GAbased optimized UPFC controller in electric power systems. Am. J. Eng. Applied Sci., 1: 45-52. DOI: 10.3844 /ajeassp.2008.45.52
Takeuchi, T., Y. Kinouchi, R. Matsui and T. Ogawa, 2015. Optimal arrangement of energy-dissipating members for seismic retrofitting of truss structures. Am. J. Eng. Applied Sci., 8: 455-464. DOI: 10.3844 /ajeassp.2015.455.464

Taraza, D., N.A. Henein and W. Bryzik, 2001. The frequency analysis of the crankshaft's speed variation: A reliable tool for diesel engine diagnosis. J. Eng. Gas Turbines Power, 123: 428-432. DOI: $10.1115 / 1.1359479$

Tesar, D. and G.K. Matthew, 1974. The Design of Modeled Cam Systems. In: Cams and Cam Mechanisms, Rees Jones, J. (Ed.), MEP, London and Birmingham, Alabama.

Theansuwan, W. and K. Triratanasirichai, 2011. The biodiesel production from roast Thai sausage oil by transesterification reaction. Am. J. Eng. Applied Sci., 4: 130-132.

DOI: 10.3844/ajeassp.2011.130.132

Thongwan, T., A. Kangrang and S. Homwuttiwong, 2011. An estimation of rainfall using fuzzy setgenetic algorithms model. Am. J. Eng. Applied Sci., 4: 77-81. DOI: 10.3844/ajeassp.2011.77.81

Tourab, W., A. Babouri and M. Nemamcha, 2011. Experimental study of electromagnetic environment in the vicinity of high voltage lines. Am. J. Eng. Applied Sci., 4: 209-213. DOI: 10.3844/ajeassp.2011.209.213

Tsolakis, A.D. and K.G. Raptis, 2011. Comparison of maximum gear-tooth operating bending stresses derived from niemann's analytical procedure and the finite element method. Am. J. Eng. Applied Sci., 4: 350-354. DOI: 10.3844/ajeassp.2011.350.354

Vernardos, S.M. and C.J. Gantes, 2015. Cross-section optimization of sandwich-type cylindrical wind turbine towers. Am. J. Eng. Applied Sci., 8: 471480. DOI: 10.3844/ajeassp.2015.471.480

Wang, L., T. Liu, Y. Zhang and X. Yuan, 2016. A methodology for continuous evaluation of cloud resiliency. Am. J. Eng. Applied Sci., 9: 264-273. DOI: 10.3844/ajeassp.2016.264.273

Wang, L., G. Wang and C.A. Alexander, 2015. Confluences among big data, finite element analysis and high-performance computing. Am. J. Eng. Applied Sci., 8: 767-774.

DOI: 10.3844/ajeassp.2015.767.774

Wang, J. and Y. Yagi, 2016. Fragment-based visual tracking with multiple representations. Am. J. Eng. Applied Sci., 9: 187-194. DOI: 10.3844/ajeassp.2016.187.194

Waters, C., S. Ajinola and M. Salih, 2016. Dissolution sintering technique to create porous copper with sodium chloride using polyvinyl alcohol solution through powder metallurgy. Am. J. Eng. Applied Sci. 9: 155-165. DOI: 10.3844/ajeassp.2016.155.165 
Wessels, L. and H. Raad, 2016. Recent advances in point of care diagnostic tools: A review. Am. J. Eng. Applied Sci., 9: 1088-1095. DOI: 10.3844/ajeassp.2016.1088.1095

Wiederrich, J.L. and B. Roth, 1974. Design of Low Vibration Cam Profiles. In: Cams and Cam Mechanisms, Rees Jones, J. (Ed.), MEP, London and Birmingham, Alabama.

Yan, C., F. Gao and W. Guo, 2009. Coordinated kinematic modeling for motion planning of heavyduty manipulators in an integrated open-die forging center. J. Eng. Manufacture, 223: 1299-1313.

Yang, M.F. and Y. Lin, 2015. Process is unreliable and quantity discounts supply chain integration inventory model. Am. J. Eng. Applied Sci., 8: 602610. DOI: 10.3844/ajeassp.2015.602.610

Yeargin, R., R. Ramey and C. Waters, 2016. Porosity analysis in porous brass using dual approaches. Am. J. Eng. Applied Sci., 9: 91-97. DOI: 10.3844/ajeassp.2016.91.97

You, M., X. Huang, M. Lin, Q. Tong and X. Li et al., 2016. Preparation of $\mathrm{LiCoMnO}_{4}$ assisted by hydrothermal approach and its electrochemical performance. Am. J. Eng. Applied Sci., 9: 396-405. DOI: 10.3844/ajeassp.2016.396.405

Zeferino, R.S., J.A.R. Ramón, E. de Anda Reyes, R.S. González and U. Pal, 2016. Large scale synthesis of $\mathrm{ZnO}$ nanostructures of different morphologies through solvent-free mechanochemical synthesis and their application in photocatalytic dye degradation. Am. J. Eng. Applied Sci., 9: 41-52. DOI: 10.3844/ajeassp.2016.41.52

Zhao, K., H. Wang, G.L. Chen, Z.Q. Lin and Y.B. He, 2010. Compliance process analysis for forging manipulator. J. Mech. Eng., 46: 27-34.

Zhao, B., 2013. Identification of multi-cracks in the gate rotor shaft based on the wavelet finite element method. Am. J. Eng. Applied Sci., 6: 309-319.

DOI: $10.3844 /$ ajeassp.2013.309.319s
Zheng, H. and S. Li, 2016. Fast and robust maximum power point tracking for solar photovoltaic systems. Am. J. Eng. Applied Sci., 9: 755-769. DOI: $10.3844 /$ ajeassp.2016.755.769

Zotos, I.S. and T.N. Costopoulos, 2009. On the use of rolling element bearings' models in Precision maintenance. Am. J. Eng. Applied Sci., 2: 344-352. DOI: 10.3844/ajeassp.2009.344.352

Zulkifli, R., K. Sopian, S. Abdullah and M.S. Takriff, 2008. Effect of pulsating circular hot air jet frequencies on local and average nusselt number. Am. J. Eng. Applied Sci., 1: 57-61. DOI: 10.3844/ajeassp.2008.57.61

Zulkifli, R., K. Sopian, S. Abdullah and M.S. Takriff, 2009. Experimental study of flow structures of circular pulsating air jet. Am. J. Eng. Applied Sci., 2: 171-175. DOI: 10.3844/ajeassp.2009.171.175

Zurfi, A. and J. Zhang, 2016a. Model identification and wall-plug efficiency measurement of white LED modules. Am. J. Eng. Applied Sci., 9: 412-419. DOI: 10.3844/ajeassp.2016.412.419

Zurfi, A. and J. Zhang, 2016b. Exploitation of battery energy storage in load frequency control-a literature survey. Am. J. Eng. Applied Sci., 9: 1173-1188. DOI: 10.3844/ajeassp.2016.1173.1188

\section{Source of Figures:}

Petrescu, RVV., 2012; Petrescu et al., 2000. 